МІНІСТЕРСТВО ОСВІТИ І НАУКИ УКРАЇНИ

БІЛОЦЕРКІВСЬКИЙ НАЦІОНАЛЬНИЙ АГРАРНИЙ УНІВЕРСИТЕТ МІЖНАРОДНИЙ НАВЧАЛЬНО-НАУКОВИЙ ІНВЕСТИЦИЙНИЙ ЦЕНТР

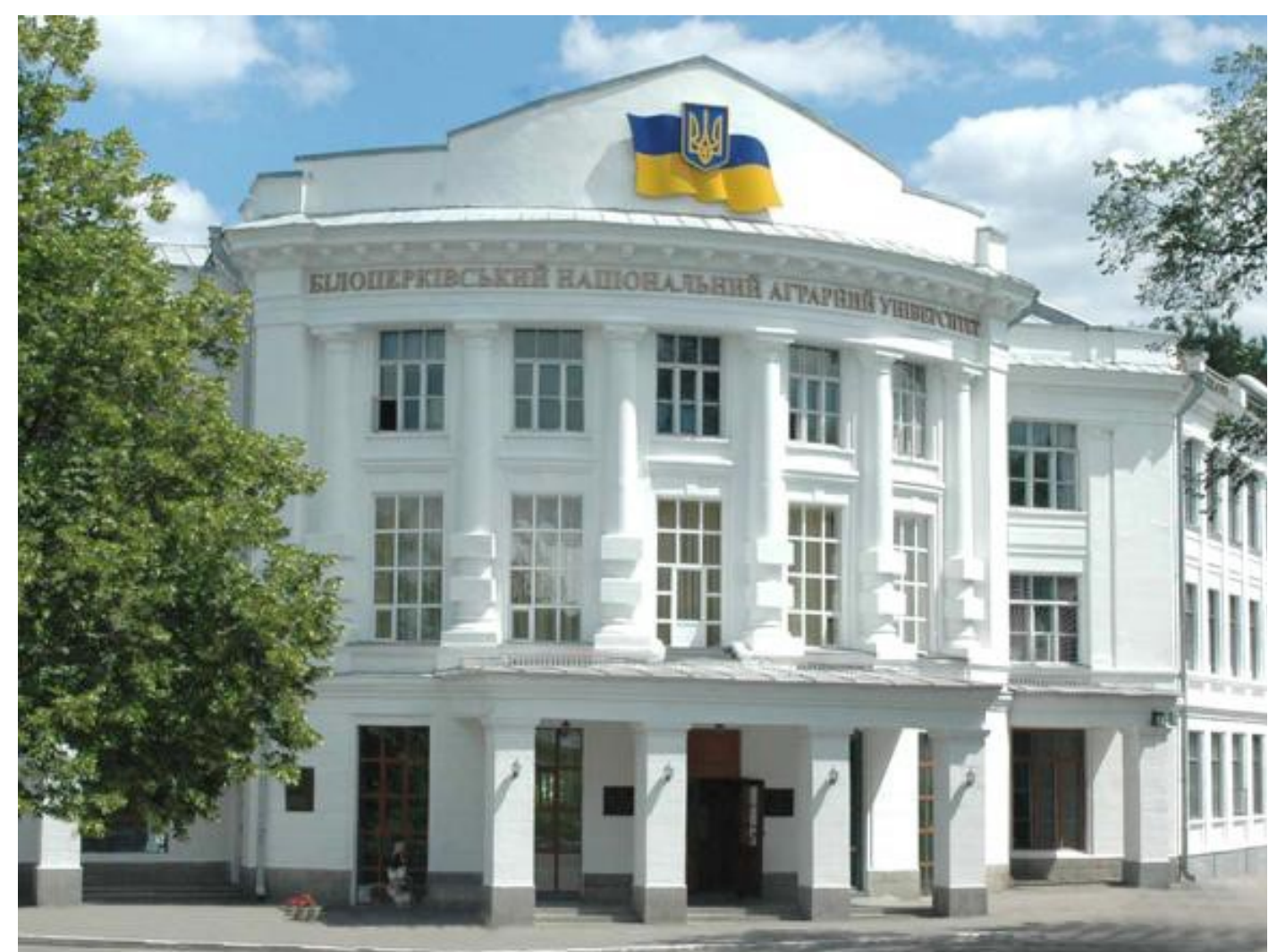

II Міжнародна науково-практична конференияія

\title{
МОВНА ОСВІТА В СУЧАСНИХ ЗВО: ТЕНДЕНЦЇ̈, ВИКЛИКИ, ПЕРСПЕКТИВИ
}

ЗБІРНИК ДОПОВІДЕЙ

(електронне видання)

20-21 травня 2021 року

Біла Церква 


\section{УДК 378.016:81(063)}

Мовна освіта в сучасних 3ВО: тенденції, виклики, перспективи: збірник доповідей II Міжнародної науково-практичної конференції, 20-21 травня 2021 р. / За заг. ред. А. О. Будугая. - Біла Церква: БНАУ. - 81 с.

Збірник містить матеріали доповідей учасників II Міжнародної науково-практичної конференції «Мовна освіта в сучасних ЗВО: тенденції, виклики, перспективи», що присвячені висвітленню актуальних питань мовної освіти в сучасних ЗВО.

\section{Рецензенти:}

Олена Юріївна Матушек, д. філол. наук, професор, завідувач кафедри історії української літератури Харківського національного університету імені В.Н. Каразіна.

Лариса Василівна Бережан, канд. філол. наук, доцент кафедри української літератури Чернівецького національного університету імені Ю. Федьковича.

\section{Загальна редакція:}

Андрій Олександрович Будугай, асистент кафедри мовної підготовки Міжнародного навчально-наукового інвестиційного центру (МННІЦ) Білочерківського національного аграрного університету.

\section{Редакційна рада:}

Тетяна Миколаївна Рудакова, канд. філол. наук, дочент, в. о. завкафедри мовної підготовки Міжнародного навчально-наукового інвестиційного центру Білоцерківського національного аграрного університету.

Ольга Дмитрівна Будугай, дочент кафедри мовної підготовки МННІЦ БНАУ;

Лілія Анатоліївна Роман, канд. філологічних наук, Чернівеиький відділ Всеукраїнської громадської організачії Союзу Українок; БHАУ.

Слизавета Юріївна Скрипкіна, асистент кафедри мовної підготовки МННІЦ

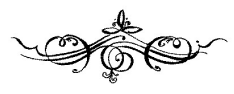

https://science.btsau.edu.ua/

Автори несуть відповідальність за достовірність фактів, цитат, посилань на джерела та вживання власних імен.

Права застережені:

(C) Кафедра мовної підготовки МННІЦ БНАУ, 2021

(C) Автори доповідей Збірника, 2021 


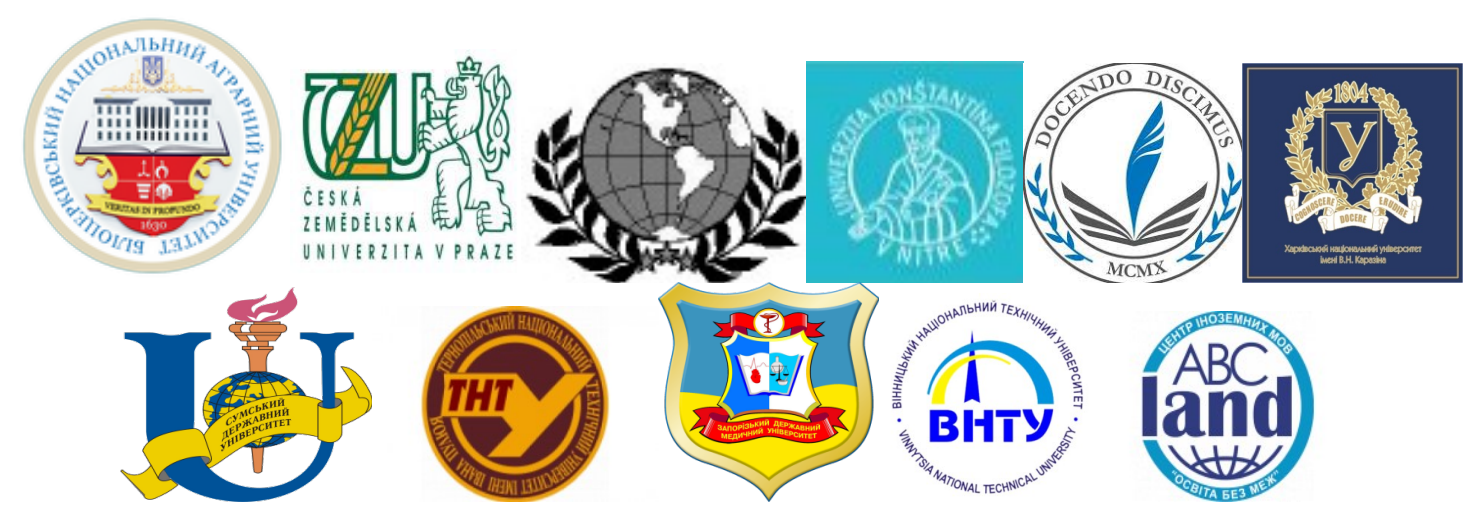

Білоцерківський національний аграрний університет

(Україна, м. Біла Церква)

Кафедра мовної підготовки МННІЦ

Czech University of Life Sciences

Чеський університет природничих наук (Чехія, м. Прага)

Deutsch-Ukrainische Wissenschaftliche Gesellschaft e. V. in München (DUWG)

Німецько-українське наукове Об'сднання імені Юрія Бойка-Блохина

(Німеччина, м. Мюнхен)

Институт за исторически изследвания, Българска академия на науките Інститут історичних досліджень Болгарської академії наук

(Болгарія, м. Софія)

Univerzita Konštantína Filozofa v Nitre

Університет імені Костянтина Філософа (Словаччина, м. Нітра)

Віцебскі дзяржаўны ўніверсітэт імя П.М. Машэрава

Вітебський державний університет імені П. М. Машерова

(Білорусь, м. Вітебськ)

Харківський національний університет імені В. Н. Каразіна

(Україна, м. Харків)

Кафедра мовної підготовки 1

Навчально-наукового інституту міжнародної освіти

Вінницький національний технічний університет (Україна, м. Вінниця) Кафедра іноземних мов

Запорізький державний медичний університет (Украӥна, м. Запоріжжя)

Кафедра мовної підготовки

Сумський державний університет (Украӥна, м. Суми)

Кафедра мовної підготовки іноземних громадян

Тернопільський національний технічний університет

імені Івана Пулюя (Украӥна, м. Тернопіль)

Кафедра української та іноземних мов

Abcland, центр іноземних мов (Україна, м. Одеса)

Екзаменаційний центр університету Cambridge 


\section{MICT}

II Міжнародна науково-практична конференція «Мовна освіта в сучасних ЗВО: тендениії, виклики, перспективи»

1. Тетяна Миколаївна Алекссєнко, Ірина Миколаївна Кушнір, Наталія Ігорівна Ушакова (м. Харків, Україна)

Навчальний комплекс з украӥнської мови «паралель» для англомовних студентів-нефілологів

2. Яна Степанівна Білик, Микола Іванович Лісовий (м. Вінниця, Україна)

Навчання іноземних студентів української вимови

3. Дарина Дмитрівна Блохин (м. Мюнхен, Німеччина) Психолого-педагогічні засади подолання труднощів у вивченні іноземноїмови

4. Андрій Олександрович Будугай (м. Біла Церква, Україна) Етапи роботи над скоромовками у процесі дистанційного вивчення української мови іноземними слухачами. Використання гарячих (швидких) клавіш під час підготовки матеріалів занять .................

5. Ольга Дмитрівна Будугай (м. Біла Церква, Україна) Культурологічний проєкт «Сім чудес України» як ефективне джерело вивчення лінгвокраїнознавства іноземними громадянами .

6. Лідія Прокопівна Гайдук, Наталія Валентинівна Гроссу (м. Запоріжжя, Україна)

Online course as a means of organizing the independent work of students of the pre-university stage of preparation

7. Наталія Олегівна Димань (м. Біла Церква, Україна) Метод «синквейн» у практиці викладання украйнської мови як іноземної

8. Ірина Мирославівна Захарків (м. Суми, Україна)

Переваги застосування лінгвокраӥнознавчого підходу у викладанні української мови як іноземної

9. Ірина Свгеніївна Зозуля (м. Вінниця, Україна)

Розвиток іншомовної дискурсивної компетенції іноземних студенmis

10. Кристьо Йорданов (м. Софія, Болгарія)

Османсько-турецькі назви видів соколів та яструбів, а також різних видів діяльності, пов'язаних з мисливськими потребами султанського двору та вищих державних службовиів в Османській імперії згідно з османськими документами XV-XVI століть

11. Алёна Іванауна Калечиц (м. Нітра, Словаччина)

Творческий подход в обучении письменной речи словачких студентов, изучающих русский язык

12. Юлія Григорівна Косенко (м. Суми, Україна)

Комунікативні ситуаиї у процесі навчання украӥнської мови як іноземної 
13. Лариса Михайлівна Кужелсва, Катерина Іллівна Старостенко (м. Суми, Україна)

Організація самостійної роботи з украӥнської мови іноземних слухачів довузівського етапу підготовки ....................................

14. Віталій Володимирович Макарчук (м. Біла Церква, Україна) Українська мова як чинник національної безпеки (правові аспекти) ..

15. Олександр Іванович Нікітенко (м. Біла Церква, Україна)

Правове регулювання у сфері застосування украйнської мови (адміністративний аспект) .......................................................

16. Ольга Валеріївна Нітенко (м. Київ, Україна)

Особливості навчання австрійських студентів в умовах пандемії COVID-19

17. Вікторія Валеріївна Новікова (м. Біла Церква, Україна).

Академічна мобільність як фактор інтеграції України в європейський науково-освітній простір

18. Лілія Анатоліївна Роман (м. Чернівці, Україна)

Вивчення української мови на матеріалах культурної спадщини України як потужний чинник у збагаченні світогляду та покращенні адаптащії іноземних студентів

19. Тетяна Миколаївна Рудакова (м. Біла Церква, Україна - м. Нітра, Словаччина)

Особливості використання діалогу-розпитування на заняттях 3 украйнської мови як іноземної

20. Слизавета Юріївна Скрипкіна (м. Біла Церква, Україна)

Ефективні шляхи свідомого засвоєння нової лексики слухачами мовного курсу

21. Алла Сергіївна Стадній (м. Вінниця, Україна)

Організаиія самостійної роботи студентів у процесі вивчення української мови як іноземної

22. Ірина Семенівна Товт (м. Біла Церква, Україна)

Культурологічний підхід до викладання украӥнської мови та літератури у $3 B O$

23. Ірина Володимирівна Черновалюк (м. Одеса, Україна)

Инновачионные технологии в иноязычном образовании 


\section{II Міжнародна науково-практична конференція «Мовна освіта в сучасних 3ВО: тенденції, виклики, перспективи»}

Онлайн-конференція, організована кафедрою мовної підготовки Міжнародного навчально-наукового інвестиційного центру Білоцерківського національного аграрного університету, відбулася 20 - 21 травня 2021 року.

Співорганізаторами конференції виступили:

- Чеський університет природничих наук (Чеська Республіка, м. Прага);

- Німецько-українське наукове Об'єднання імені Юрія Бойка-Блохина (Німеччина, м. Мюнхен);

- Інститут історичних досліджень Болгарської академії наук (Республіка Болгарія, м. Софія)

- Університет імені Костянтина Філософа (Словацька Республіка, M. Himpa);

- Вітебський державний університет імені Петра Машерова (Республіка Білорусь, м. Вітебськ);

- перша кафедра мовної підготовки Навчально-наукового інституту міжнародної освіти Харківського національного університету імені Василя Каразіна (Україна, м. Харків);

- кафедра іноземних мов Вінницького національного технічного університету (Украӥна, м. Вінниия);

- кафедра мовної підготовки Запорізького державного медичного університету (Украӥна, м. Запоріжжя);

- кафедра мовної підготовки іноземних громадян Сумського державного університету (Украӥна, м. Суми);

- кафедра української та іноземних мов Тернопільського національного тех.нічного університету імені Івана Пулюя (Україна, м. Тернопіль);

- Екзаменаційний центр університету Cambridge Abcland, центр іноземних мов (Украӥна, м. Одеса).

Учасників конференції привітали професори Віталій Петрович Новак (перший проректор БНАУ), Дарина Дмитрівна Блохин (Президент НУНО, $Ф Р Н)$, Тетяна Василівна Нікітіна (Білорусь), Олександр Анатолійович Скляренко (Китай).

Упродовж двох днів конференції лунали цікаві доповіді колег із різних куточків України та зарубіжжя. Науковці-методисти активно ділилися накопиченим досвідом, розкривали важливі нюанси роботи з іноземними здобувачами освіти.

Після виступів доповідачів нерідко тривала наукова дискусія, активними учасниками якої були досвідчені викладачі Ірина Євгенівна Зозуля (м. Вінниця), Альона Іванівна Калечиц (Білорусь - Словаччина), Ольга Вікторівна Гриценко (м. Запоріжжя), Марія Ігорівна Тихоновська (м. Одеса), Лілія Анатоліївна Роман (м. Чернівці), Ірина Миколаївна Кушнір (Харків), Ірина Анатоліївна Рижова (Київ). Вони не тільки обговорювали порушені доповідачами проблеми, але й давали слушні поради з власного досвіду праці з інокомунікантами. 
Доповіді співорганізаторів конференції доповнили представники таких навчальних закладів:

- Університету Григорія Сковороди в Переяславі,

- Вінницького національного медичного університету імені Миколи Пирогова,

- Київського національного університету імені Тараса Шевченка,

- Одеського національного університету імені Іллі Мечникова,

- КЗ КОР «Білоцерківський гуманітарно-педагогічний фаховий коледж»,

- Чернівецького відділу ГО Союзу Українок (м. Чернівиі)

- Відокремленого структурного підрозділу «Тернопільський фаховий коледж Тернопільського національного технічного університету імені Івана Пулюя».

На конференції прозвучали декілька мов: українська, англійська, білоруська, німецька, російська.

Дякуємо всім учасникам за плідну співпрацю та цікаві доповіді.

Тетяна Рудакова, к. філол. н., доц., в. о. зав. кафедри мовної підготовки;

Ольга Будугай, к. філол. н., доц. кафедри мовної підготовки;

Оксана Тихонова, к. філол. н., асистент кафедри мовної підготовки;

Андрій Будугай, асистент кафедри мовної підготовки;

Єлизавета Скрипкіна, асистент кафедри мовної підготовки;

Наталія Димань, асистент кафедри мовної підготовки. 
Тетяна Миколаївна Алекссєнко (м. Харків, Україна), старший викладач кафедри мовної підготовки 1 Навчально-наукового інституту міжнародної освіти Харківського начіонального університету імені В.Н. Каразіна (ННІМО ХНУ);

Ірина Миколаївна Кушнір (м. Харків, Україна), канд. пед. наук, дои.; доцент кафедри мовної підготовки 1 ННІМО ХНУ;

Наталія Ігорівна Ушакова (м. Харків, Україна) док. пед. наук, проф.; завідувачка кафедри мовної підготовки 1 ННІМО ХНУ.

\section{doi: 10.33245/20-05-2021-8-10}

\section{Навчальний комплекс з української мови «паралель» для англомовних студентів-нефілологів}

Анотація: Тенденції розвитку вищої освіти зумовлюють необхідність створення навчально-методичних комплексів для іноземних студентів різних профілів навчання відповідно до рівня володіння украӥнською мовою та мови надання освітніх послуг. У поданій доповіді схарактеризовано навчальний комплекс з украӥнської мови як іноземної для англомовних здобувачів вищяої нефілологічної освіти в Україні.

Зазначено, щз навчальний комплекс «Паралель» реалізує особливості сучасной мовноосвітньої парадигми, а його структурно-змістові елементи забезпечують реалізацію дійсних комунікативних потреб інофонів та інтенсифікацію навчання.

Ключові слова: англомовні студенти-нефілологи, навчально-методичний комплекс, українська мова як іноземна.

The topic: «Ukrainian Language Training Complex «Parallel» for English-speaking NonPhilological Students»

Abstract: Trends in the development of higher education necessitate the creation of educational and methodological complexes for foreign students of different educational profiles in accordance with the level of proficiency in the Ukrainian language and the language of educational services. The presented report characterizes the educational complex of Ukrainian as a foreign Language for English-speaking applicants for higher non-philological education in Ukraine.

It is noted that the educational complex «Parallel» implements the features of the modern language education paradigm, and it's structural and semantic elements provide the realization of real communicative needs of foreigners and intensification of learning.

Key words: educational and methodical complex, english-speaking non-philological students, Ukrainian as a foreign language.

У зв’язку з переходом на нові державні стандарти освіти в загальноєвропейському контексті та переорієнтуванням освітніх програм 3 ВО на сучасні стандартизовані вимоги особливо важливим стає створення навчальнометодичних комплексів, здатних забезпечити високу якість підготовки здобувачів. Теоретичне підгрунтя розробки методичних комплексів для навчання української мови як іноземної (далі - УМІ) складають дослідження 
сучасної методичної парадигми мовної освіти іноземців, яка представлена ієрархічною системою підходів трьох рівнів, а саме:

1) методологічного (особистісно-орієнтований, компетентнісний, освітній (самоосвіти), проблемний, стратегічний);

2) сочіолінгвістичного (культурознавчий (міжкультурний), комунікативно-когнітивний, ефективного освітнього середовища; орієнтації на певний рівень володіння мовою);

3) лінгводидактичного (шляхи організації навчального процесу, методи та засоби навчання мови) [4].

Реалізацією зазначених підходів став навчальний комплекс з УМІ «Паралель» для англомовних здобувачів вищої освіти в українських ЗВО, створений авторським колективом кафедри мовної підготовки 1 Навчальнонаукового інституту міжнародної освіти Харківського національного університету імені В.Н. Каразіна, орієнтований на формування комунікативної компетентності на рівні, достатньому для вирішення комунікативних завдань у соціально-побутовій, соціокультурній i навчально-академічній сферах спілкування, на основі формування фонетичних, лексико-граматичних навичок і вмінь в основних видах мовленнєвої діяльності - читанні, письмі, говорінні й аудіюванні, в уживанні мовних засобів для реалізації певних тактик мовленнєвої поведінки для досягнення комунікативної мети.

Навчальний комплекс «Паралель» забезпечує інтенсифіковане навчання УМІ. Він включає 3 посібники: «Вступний курс» (А1) [1], «Базовий курс» (А2) [2], «Основний курс» (B1) [3], створені на загальнолітературній лексиці та тематично й ситуативно пов'язані з життям і навчанням іноземців в Україні.

Усі розділи кожної книги навчального комплексу побудовані за розробленою авторами моделлю, що містить такі складники:

1) презентація концентрично розподіленого фонетичного, лексичного i граматичного матеріалу 3 коментарем українською та англійською мовами, відібраного за функційно-комунікативним і синтаксичним принципами;

2) комунікативні зразки, в яких реалізовано лексичний і граматичний матеріал теми;

3) система докомунікативних і умовно-комунікативних завдань, орієнтованих на комплексне й поетапне формування фонетичних, лексичних і граматичних навичок;

4) рубрика «Мовленнєва практика», комунікативні завдання якої спрямовані на формування та розвиток умінь у читанні, аудіюванні, говорінні та письмі.

Одиницями навчання в комплексі навчальних посібників $\epsilon$ тексти, адаптовані до відповідного рівня володіння мовою, та діалогічні й полілогічні єдності.

Структура навчального комплексу «Паралель» відповідає основним методичним принципам укладання посібників і підручників із мови навчання: свідомо-практичної комунікативної спрямованості навчання; особистісної та соціокультурної орієнтованості; комплексного оволодіння видами мовленнєвої діяльності; урахування особливостей використання мови-посередника. 
Таким чином, навчальний комплекс «Паралель» $є$ системою базових навчальних посібників для іноземних студентів-нефілологів англомовної форми навчання, яка реалізує сучасні підходи до викладання української мови як іноземної і має комунікативно-практичну спрямованість, ураховує особливості соціокультурного фону, сприяє інтенсифікації навчального процесу.

\section{Список літератури:}

1. Паралель : Українська мова для початківців: Вступ. курс : навч. посіб. / Н. I. Ушакова, Т. М. Алексєєнко, I. М. Кушнір, I. П. Петренко. - Харків: ХНУ ім. В. Н. Каразіна, 2018. -63 с.

2. Паралель: Українська мова для початківців: Базовий курс : навч. посіб. / Н. І. Ушакова, Т. М. Алексєєнко, І. М. Кушнір, І. П. Петренко. - Харків: ХНУ ім. В. Н. Каразіна, 2018. - 112 c.

3. Паралель. Українська мова для початківців : Основний курс: навчальний посібник. / Ушакова Н.І., Алексєєнко Т.М., Кушнір І.М., Петренко І.П. - Харків: ХНУ імені В.Н. Каразіна, 2019. - $118 \mathrm{c}$.

4. Ушакова Н.I. Принципи структурування змісту сучасного підручника 3 мови навчання для освітніх мігрантів. Викладання мов у вищих навчальних закладах освіти на сучасному етапі. Міжпредметні зв'язки. Наукові дослідження. Досвід. Пошуки. Зб. наук. праць. - Вип. 30. Х.: ХНУ імені В. Н. Каразіна, 2017. - С. 142 - 155.

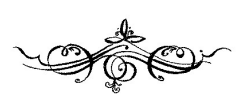

УДК 16.21.47.03

Яна Степанівна Білик (м. Вінниця, Україна), канд. філологічних наук, дочент кафедри українознавства Вінницького національного медичного університету імені М. I. Пирогова;

Микола Іванович Лісовий (м. Вінниця, Україна), канд. педагогічних наук, доцент кафедри українознавства Вінницького національного медичного університету імені М. І. Пирогова

doi: $10.33245 / 20-05-2021-10-13$

\section{Навчання іноземних студентів української вимови}

Анотація: Тези є фрагментом дослідження питань викладання української мови іноземним студентам на початковому етапі їхнього навчання, зокрема - вивчення украӥнської фонетики. Основний акиент зроблено на різних аспектах артикуляиії, які усвідомлюються на основі рухової, слухової, наочної, тактильної опор. Підкреслюється, що робота з артикуляцією украӥнських звуків проходить паралельно з вивченням словесного наголосу й оволодінням украӥнською інтонацією.

Ключові слова: артикулячія, аспекти артикулящіï, інтонація, навички вимови, наголос.

The topic: «Teaching foreign students Ukrainian pronunciation»

Abstract: Thesis are fragments of the study of issues of teaching the Ukrainian language foreign students at the initial stage of their training, in particular-study of Ukrainian phonetics. 
The main focus is on various aspects of articulation which are realized on base of motor, auditor, visual, tactile supports. We emphasize that work with articulation of Ukrainian sounds is done in parallel with study of verbal stress and mastering the Ukrainian intonation.

Key words: articulation, aspects of articulation, intonation, pronunciation skills, emphasis.

Існує три основних компоненти мови - фонетика, лексика, граматика. Фонетика посідає особливе місце в структурі мови. Звук - це не третій елемент, а необхідна форма існування слів і граматичних засобів. Фонетикою мовець має оволодіти досконало. Щоб мовлення, яке $\epsilon$ засобом спілкування, засобом передачі інформації від одного співрозмовника до іншого, успішно виконувало цю функцію, той, хто вивчає українську мову, повинен правильно вимовляти всі українські звуки, оволодіти системою звукових одиниць - фонем та інтонаційних конструкцій, сформувати слухові еталони, розвивати артикуляційну базу, слухові й вимовні навички, мовленнєвий слух.

Вивчення питань навчання вимови $з$ позицій комунікативно-діяльнісного підходу дозволило визначити місце навичок вимови в структурі мовленнєвої діяльності: вони, поряд із граматичними, належать до навичок оформлення мовленнєвих операцій і дій. Навички вимови є певною мірою універсальними, оскільки беруть участь у всіх видах мовленнєвої діяльності, створюючи важливі передумови для їх розвитку.

Слухові й вимовні навички є автоматизованими операціями, що забезпечують звукове, акцентуаційно-ритмічне й інтонаційне оформлення висловлювання. Звукове оформлення висловлення передбачає формування навичок правильної артикуляції українських звуків. У якості прийомів навчання фонетики використовуються звуки-помічники, відчутні й невідчутні аспекти артикуляції, вибір сприятливої позиції для закріплення артикуляції, що встановлюються з урахуванням артикуляційної бази як української, так і рідної мови. Для представників конкретної мови визначається своя послідовність фонетичних позицій під час закріплення певного звука.

Керовані й відчутні аспекти артикуляції усвідомлюються на основі рухової, слухової, наочної, тактильної опор. Тоді, коли неможливо відчути артикуляційні рухи, наприклад, підняття задньої спинки язика під час вимови $[л]$ або роботу голосових зв'язок під час вимови дзвінких приголосних, використовуються звуки-помічники та сприятлива фонетична позиція.

Наприклад, сприятливою позицією для вимови м'яких при голосних є позиція після $[i]$ перед $[a]-i m я$, оскільки саме в цій позиції найбільш помітний перехід від м'якого приголосного до голосного.

Під час вимови ненаголошених голосних можна використовувати в якості керованого аспекту артикуляції різний ступінь розкриття ротової порожнини (найбільший під час вимови $[a])$. Під час вимови звука $[u]$ використовуються звуки-помічники $[\kappa],[2] .[x]$, сприятливою позицією для $[u] \epsilon$ його вимова після [y].

Кожне фонетичне явище вводиться поступово, від простого до складного, шляхом залучення нових особливостей в міру ускладнення лексикограматичного матеріалу, який вивчається. Так, студенти поступово в ході 
вивчення нових слів засвоюють правила вимови не наголошених [e], [u], нескладових $[y],[i]$, поняття уподібнення звуків тощо.

Робота 3 артикуляцією українських звуків проходить паралельно 3 вивченням словесного наголосу 3 урахуванням трьох аспектів: фонетичної природи наголошування, ритмічних моделей слів i специфіки наголосу в українській мові (він є вільним, рухомим).

Уже $з$ перших уроків вивчається якість українського наголосу (виділення наголошеного складу за тривалістю й напруженістю та чіткістю його вимови), протиставлення наголошеного складу ненаголошеним; окрім того, проводиться робота з вивчення моделей односкладових, двоскладових, трискладових і більш складних слів і акцентних парадигм (груп слів із постійним наголосом, груп слів із рухомим наголосом), насамперед продуктивних акцентних парадигм іменників і дієслів із обмеженою групою слів. На наступних етапах навчання кількість акцентних парадигм i їх лексичне наповнення, звичайно, збільшується.

Завдяки таким паралельним із постановкою звуків i вивченням артикуляційних рухів сполученням властивостей українського наголосу формується мовленнєвий слух, у якості компонентів якого традиційно виділяються фонематичний (здатність розрізняти фонеми та їх варіанти) й інтонаційний слух (здатність розрізняти інтонаційні варіанти та їх моделі).

Однак обсяг мовленнєвого слуху не вичерпується двома названими компонентами. Як відомо, норми вимови кожної мови мають свою специфіку (наприклад, для української мови не характерний придих, із яким вимовляються глухі змичкові приголосні [п], [т], [к] в німецькій мові тощо).

Порушення норм вимови української мови надає мові іноземного акценту, утруднює іiі розуміння на слух, заважає засвоєнню мови, гальмує просування тих, хто вивчає мову, в усіх видах мовленнєвої діяльності. Отже, в мовленнєвому слухові, крім фонематичного й інтонаційного, виділяють іще один компонент, який відповідає за розрізнення фонетичних ознак звуків та умовно називається фонетичним.

Особливим аспектом правильної вимови $є$ оволодіння українською інтонацією, до якого належить ознайомлення з основними видами інтонаційних конструкцій (IK-1, 2, 3, 4, 5), і їх вживанням, правилами синтагматичного членування, поняттям центру ІК та його місцем у реченні, зі зміною тону на центрі ІК. Центр інтонації, як правило, закріплений за словом, яке містить головну інформацію.

У розповідному реченні звичайно центр IК міститься на останньому слові, але залежно від змісту висловлювання він може переміщатися: Петро навчається в університеті. Його брат також навчається в університеті.

У розповідному реченні центр інтонації виділяється більш інтенсивною і тривалою вимовою слова й зниженням тону: Учора він був на екскурсї (а не вона). У питальному реченні без питального слова центр ІК міститься на тому слові, яке є предикатом висловлювання й виділяється різким підвищенням тону (вищим від середнього): Ви відпочивали взимку в Карпатаx? - Tак, відпочивав. 
Нормативне інтонаційне оформлення україномовних висловлювань передбачає сформованість таких основних навичок і вмінь: сприймати диференційовані ознаки інтонаційних структур, співвідносити низку диференційованих ознак із інтонаційним варіантом, розрізняти комунікативні типи висловлень через розрізнення їх інтонаційних структур, відтворювати інтонаційну структуру фрази з опорою на інтонаційну схему або без неї тощо.

\section{Список літератури:}

1. Гелецька А. I. Методика викладання української мови як іноземної у вищих навчальних закладах [Електронний ресурс] / А. І. Гелецька - Режим доступу до ресурсу: http://www.rusnauka.com/29_DWS_2011/Philologia/1_95313.doc.htm.

2. Донченко Т. К. Вивчення фонетики української мови студентами-іноземцями / Т. К. Донченко // Теорія і практика викладання української мови як іноземної. - 2010. Вип. 5. - С. 75-81.

3. Мелкумова Т. В. Формування фонетико-орфоепічної компетенції студентів при вивченні української мови як іноземної / Т. В. Мелкумова // Філологічні студії. - 2012. Вип. 7. - Ч. 2. - С. 292-298.

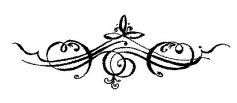

УДК 37.015.3:81’243-028.31

Дарина Дмитрівна Блохин (м. Мюнхен, Німеччина),

кан. пед наук, доктор філософії, почесний професор і доктор Університету імені Григорія Сковороди в Переяславі, почесний академік Академії наук вищзоі школи України, член-кореспондент Украӥнської Вільної Академії наук у НьюЙорку, Лауреат премії Фонду імені Тараса Шевченка, президент «Німецькоукраїнського наукового об 'єднання імені Юрія Бойка-Блохина» в Німеччині

\section{doi: $10.33245 / 20-05-2021-13-18$}

\section{Психолого-педагогічні засади подолання труднощів у вивченні іноземної мови}

Анотація: У статті аналізуються психолого-педагогічні засади вивчення іноземної мови. Авторка вдається до історичних екскурсів, наводить яскраві приклади опанування іноземної мови, дає конкретні поради психологічного подолання труднощів у вивченні мови.

Ключові слова: іноземна мова, входження в чужу мову, компактний модуль, комбінування слів, автоматизація, світова мова глобіш.

Тема: «Psychological and pedagogical foundations of overcoming difficulties in learning a foreign language»

Annotation: The article analyses the psychological and pedagogical principles of learning a foreign language. The author resorts to the historical insights, gives vivid examples of mastering a foreign language, gives specific advice on psychological overcoming of difficulties in learning a language.

Key words: foreign language, entering a foreign language, compact module, word combination, automation, world language Globish. 
У різні епохи перед тими, хто мав потребу у вивченні іноземної мови, поставала проблема психологічного подолання труднощів, мовного бар'єру. Відтак мета нашої статті - навести вагомі приклади опанування інокомунікантами іноземної мови, ознайомити 3 конкретними порадами щодо психологічного подолання труднощів у вивченні мови.

Перегорнемо кілька сторінок історії. У німецькій і англійські мові алфавіт складається із латинських букв, які придумали латини, горді племена, що жили у Давньому Римі. Як алфавіт латинів потрапив у Великобританію? Щоб відповісти на це запитання, повернемося на багато віків назад. Великобританія - це великий острів. Він відділений від материка, від території сусідньої Франції протокою, яку англійці називають Англійським каналом, а Французи Па-де-Кале.

3 давніх-давен острів, на якому зараз розміщена Великобританія, був заселений різними племенами: піктами і скотами. Потім тут мешкали давні альпійські раси, які ставили моноліти; один із найбільш відомих кам'яних пам'яток Англії - Стоунхендж. Потім цю землю заселили кельтські племена. Кожне із них мало свою назву, найбільш численне називалося британцями. Тому острів згодом назвали Британією.

Кельти створили знаки, вони вирубували їх на каменях або вирізали на дереві за допомогою кам'яних знарядь праці. Такі знаки називалися рунами. Руна означала ціле слово, поняття. Археологи такі пам'ятки письменності знаходять рідко. Брити жили в залізному віці, коли мечі, сокири та інші знаряддя праці виготовляли із заліза. Одягалися вони в шкури тварин. Обличчя розмальовували у синій колір, щоб лякати ворогів, бо воювали в ті часи постійно.

Але, що трапилося з алфавітом, як латинські букви потрапили в Англію? Давній Рим став могутньою і сильною країною. Римляни були завойовниками, захоплювали інші країни, а людей перетворювали в рабів. Юлій Цезар, знаменитий римський полководець, захопив Галлію (сучасна Франція) i вирішив далі завоювати далекий острів, заселений в ті часи кельтами. Римська армія переплила протоку і напала на жителів острова.

Але населення було мужнє. Пофарбувавши волосся й вуса в червоний колір, а руки і ноги в білий, кельти хоробро боролися з римським військом. Та римляни їх перемогли. Завойовники примусили цей народ не тільки працювати, але й говорити та писати на їхній мові. Так латинський алфавіт уперше потрапив на острів. Кельти продовжували чинити опір і говорили на своїй кельтській мові. Латина накладалася на місцеві мови.

У результаті дві мови змішались. Ще довго Римська імперія утверджувала своє панування над кельтами, римляни заставляли їх писати латинськими буквами. Але хоч i латинський алфавіт потрапив до Англії разом із завойовниками, самі прості римляни (солдати, ветерани, торговці) ніколи не говорили літературною латинською мовою, вони говорили своєю «вульгарною», тобто народною мовою. Але документи писали високою латинською мовою.

Римська імперія 3 часом ослабла, і завойовники покинули острів. Але недовго прожили кельти в мирі. На острів напали германські племена англів, 
саксів і ютів. Англи були такі численні, що острів став називатися Англією. Вони принесли з собою давньогерманську мову, насаджували свою мову. Так поступово i формувалася англійська мова, яка складалася із елементів кельтської, латинської, давньогерманської, нормандської та інших мов і діалектів, - інших варіантів, - характерних для різних місцевостей.

Коли ми починаємо з вами вчити німецьку й англійську мови, які дуже поширені в світі, то кожен $з$ нас зрозуміє, що в нас буде багато друзів, щоб можна було працювати з ученими різних країн. Мови потрібно вчити, бо це вікно в спілкуванні з людьми різних націй. Щоб добре вивчити мову, людині потрібно все життя. А щоб навчитися говорити, спілкуватися треба вміти «перемикатися» в залежності від мотивації. Це потребує теж чимало часу i бажання, а також енергії і зусиль.

Мова окремого народу - це об'ємне, багатовимірне сприйняття. I слід не тільки знати слова чужої мови, а треба відчути свою присутність у цьому мовному середовищі, слід психологічно увійти в образ або емоційне відчуття, що викликає у кожного якісь асоціації: почуття, образи, емоції, мелодика, з якою чужа мова пов'язана. Мова - це не просто так, як ви зустрічаєте людину, знайомитися, приглядаєтеся, звикаєте i навіть закохуєтесь; це не тільки письмовий вираз, це ціла психологія, це багатогранний простір культури, ставлення до мистецтва, до ментальності людей, дружба, уява, спомини 3 відчуттями. Коли мовець у це заглиблюється - тоді і текст мови стає зрозумілим.

Виокремимо головні, на нашу думку, моменти у вивченні мови:

1. Не боятися робити помилок, бо на них ми вчимося. Ми будемо вчитися одразу говорити. Синдром страху буде наявним, i його слід пересилити, бо це гальмує розмову. I постаратися пересилити напругу, яка виникає на фізичному рівні. Це зрозуміло, бо ми входимо на незнайому територію іноземної мови - як чужинці. Кожна помилка - це мікротравма, яка приводить до страху, комплексує і гальмує процес запам'ятовування, але слід зміцнювати свою мотивацію, щоб мову робити потрібною для вираження, робити іiі пластичною, об'ємною. Це так як у житті буває, коли ми робимо помилки, на яких вчимося і прагнемо більше не робити їх.

У вивченні мови слід переборювати все складне, але не перевантажуючи себе до безмежної границі. Слід пам'ятати, що психіка людини влаштована за принципом входження у мову: що іноді коли не все вдається, але воно закарбовується. I потім настає момент входження в мову - і людина вже говорить правильно. Часто наступає момент входження у мову так глибоко, що навіть можна бачити сни тією ж іноземною мовою, що $є$ великим позитивом. Людина осягнула необхідність знати чужу мову. Тоді стаються зміни в психіці: вона стає сміливішою і пробує говорити, знаючи базові структури - алгоритми.

Треба налаштуватися на образ, який дозволяє не допустити напруження, а ще краще, щоб відчуття страху не виникало у людини. А треба увійти в об'ємний образ мови шляхом відчуттів, які допомагають робити мову зрозумілою і об'ємною, як, наприклад, колір, смак, запах, якісь предмети чи події, або музика (слухові явища), яка нагадує про щось і т. д. Важливо, що людина при бажанні може всього досягнути, при певній мотивації. 
2. Автоматичне засвоєння базових структур. Наприклад: візьмемо дієслова, яким чином вони зміняються за числом, особою, формами закінчень. Які вони в питальних, стверджувальних, заперечних фразах? Як змінюються дієслова за часовими формами; як дієслова позв'язуються з іншими частинами мови: $з$ іменниками, займенниками, прислівниками, сполучниками і т. д. Це потрібно для того, щоб вміти будувати речення і вчитися розмовляти іноземною мовою. Адже $є$ багато розмовних тем, текстів, які повторюються: бесіда про себе, вміти задавати питання, давати відповіді, про роботу i спеціальність, знайомство, подорожі, готелі тощо. Усе це є прості структури , які потребують знань мінімального рівня іноземної мови.

Для цього слід знати слова, які нанизуються, як намистинки на нитку, утворюючи так звані алгоритми - це послідовні комбінації із невеликої кількості слів. Знаючи їх, ми можемо будувати багато речень. Використовуючи нові слова, нанизуємо їх, як намистинки, на нитку в правильному порядку - i отримуємо речення. Алгоритми - це матриця. I це не корелюється запасом слів - можна знати й багато слів, але при цьому не вміти говорити.

$€$ різні рівні вивчення мови, це залежить від мотивації і бажання людини. Статистика говорить, що 90 \% мови базується на знанні 300-350 слів, з яких припадає 50-60 дієслів, які є основою нашої мови, користуючись якими ми можемо запитувати, відповідати, стверджувати або заперечувати. Все це слід вчити одночасно.

Об’єм інформації не перевищує таблиці множення, тобто ми повинні вивчити декілька базових структур, - алгоритмів, - i довести їх до автоматизації, вивести на такий рівень, як автоматично розмовляємо на рідній мові, не думаючи про граматику, про структуру, чи як працюють наші ноги, коли ми йдемо т. б., довести вивчення мови до автоматизації. Адже багато слів ви знаєте, ці слова ви чули, особливо в комп'ютеризації, ваші знання слід лише упорядкувати, і ви будете це робити.

А в майбутньому ці структури використовуються для побудови складних речень, правильно граматично перекладати тексти, писати статті тощо. Мова це спосіб переключатися, як у приймачі, чи в телевізорі, ви натискуєте на кнопки. Тому слід вміти комбінувати відомі і нові слова у реченнях. Адже дитина говорить тоді, коли вона автоматично будує спочатку речення із відомих слів, т. б. коли починає працювати комбінаторика. I ми теж можемо це робити, в незалежності від кількості відомих слів, комбінувати їх у речення. А згодом використовувати для цього і нові слова.

Ми повинні вивчити мову шляхом щоденного повторення основних базових структур, які дають можливість створити комбінації слів у реченні, в залежності від професії, мотивації на елементарному рівні, а потім їх удосконалювати. Мову треба розглядати не як енциклопедію, а як сегменти, 3 яких будуються речення. I на кожному етапі додавати нові алгоритми, в залежності від мотивації.

Мова - це живий організм, вона характеризується психологічним сприйняттям. Вона викликає емоції, в залежності від ментальності народу, історичних умов, від культури нації, рівня розвитку техніки і має властивості 
змінюватися, набираючи нових термінів, конкретності, особливо в технічних цілях в залежності від потреб технічного прогресу.

Для об'ємного знання мови не достатньо знати лише слова, а слід зануритися в їі середовище і підключити образ емоційного відчуття.

Мова викликає конструктивні асоціації, наприклад, коли говоримо про Італію, виникає асоціація з чудовою музикою, темпераментом людей та навіть із піцою, пастою і т.д. Французька мова асоціюється у свідомості з круасаном, який, на мою думку, найсмачніший тільки у Франції; а коли говоримо українською мовою, то вона викликає асоціації в різних напрямках, як український одяг, національні пісні й музика, високопочуттєві ознаки ментальності.

Головне у вивченні мови - створити психологічну атмосферу для людини, яка б відчула свободу, допомогу, товариське відношення, дружелюбність без критики, без нарікань. Цим самим, основним мотиваційним фактором у вивченні мови повинні бути - свобода і задоволення. Слід вміти зняти напругу, таким способом: глибоко вдихнути і глибоко видихнути, і ця вправа звільняє людину від напруги.

Задоволення підкріплюється музикою, телепрограмами мовою, яку ми вивчаємо, читанням коротких текстів. Корисно вчити вірші, дивитися кінофільми спочатку на рідній мові, потім із титрами, а потім без них, так легше переключитися з рідної мови на іншу. Мову слід вивчати компактним модулем - кожен день і повторяти декілька хвилин основні алгоритми.

Постає питання: як ефективніше вчити мову? Мені здається, що найкраще опановувати мову із носієм мови, але, щоб він знав і вашу рідну мову. Інакше слухачі, чи учні відчувають страх, невпевненість, не розуміють про що йде мова, і тоді втрачають бажання вчити мову. Таке занурення у чужу мову, без знань вчителя мови слухачів, можна проводити на вищому рівні, коли учні уже засвоїли базовий рівень основних алгоритмів, мають деякий запас слів.

Слід розуміти, що мова - живий організм, який із розвитком історичних умов, менталітету, розвитком техніки набуває нових ознак, нових термінів. Так, в Англії в давні часи престижною була французька мова, а англійською розмовляв простий люд. Але із історичним розвитком відбувся демографічний вибух: Англія стала на шлях захоплення інших територій, колоній, на шлях прагматизму, ефективності, розвитку техніки, культури, і виникла необхідність у зміні мови, вона стала інакшою, як в древні віки.

I в середині XX ст. англійська мова стала мовою масовою культури, техніки, комп'ютеризації. Наступила експансія інших країн. Англійська мова стала глобальною, світовою. Але при вивченні німецької мови ви будете знаходити слова, словосполучення одинакові. I тому, знаючи уже бодай одну іншу мову, легше вчити кожну наступну чужу мову.

Очевидно, виробиться нова світова мова - глобіш - в окремих сферах техніки, на базі англійської мови, із спрощеними конкретними лексичними термінами для того, щоб могли спілкуватися фахові люди, при обговорюванні різних проблем, на зрозумілій для всіх мові. Але, це не значить, що елітарні мови різних національностей зникнуть. Ні, вони будуть розвиватися i далі, бо кожна нація має свою мову, менталітет, культуру, історію, які слід берегти. 
Отже, іноземна мова відкриває вікно для спілкування представників різних націй, розвитку інтелекту людини. Вона $є$ потужним виховним фактором і необхідним елементом для формування кожної інтелігентної людини.

\section{Список літератури:}

1. Blochyn D. Deutsch. Grundlage. München, 2020. 47 Seiten.

2. Blochyn D. Modern English. Grammatik. Munich, 2020. 70 pages.

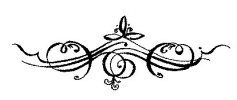

УДК 378.018.43:811.161.2-845

Андрій Олександрович Будугай (м. Біла Церква, Україна), асистент кафедри мовної підготовки Міжнародного навчально-наукового інвестиційного центру Білоцерківського наџіонального аграрного університету

doi: 10.33245/20-05-2021-18-24

\section{Етапи роботи над скоромовками у процесі дистанційного вивчення української мови іноземними слухачами. Використання гарячих (швидких) клавіш під час підготовки матеріалів занять}

Анотація: У статті йдеться про основні етапи роботи над скоромовками у процесі вивчення фонетики украӥнськой мови слухачами мовного курсу. Звернено увагу на особливості підготовки методичних матеріалів для освітнього процесу в умовах онлайн навчання.

Ключові слова: дистанщійне навчання, украйнська мова як іноземна, скоромовка, артикулячія, вимова, говоріння, «гарячі клавіші».

The topic: «The stages of the work on colloquialisms in the process of distance learning of the Ukrainian language by foreign students. Use of hot (short) keys during preparation of materials of employment»

Abstract: The article is about the main stages of the work on tongue twisters in the process of learning phonetics of the Ukrainian language by the students of the language course. Attention is paid to the peculiarities of preparing the methodological materials for the educational process under online learning.

Key words: remote learning, Ukrainian as a foreign language, tongue twister, articulation, pronunciation, speaking, shortcut keys.

За визначенням 11-томного академічного «Словника української мови» термін «скоромовка» має два значення: «1. Швидка, поспішна мова або швидкий темп мови», а також «2. Жанр народної творчості - жартівливий вислів, скомпонований із важких для швидкої вимови слів» [8].

У нашому дослідженні ми беремо до уваги друге значення цього терміну. При цьому зробимо акцент, що скоромовки можуть бути не тільки продуктом 
інтелектуальної діяльності народу, але й мати літературне походження. Так, за визначенням Вікіпедії, скоромовка (або швидкомовка) - це «жанр як фольклорного, так і літературного походження: дотепна гра спеціально скомпонованих важковимовних слів, і звуків, що створюють труднощі для швидкої й виразної вимови слів. Зазвичай має форму ритмізованої прози, іноді римованої. Зміст скоромовки найчастіше жартівливий» [7].

Скоромовки мають важливе значення перш за все під час навчання рідної мови звичайних дітей і «дітей з фонетико-фонематичними вадами мовлення, орфоепічними дефектами, порушенням артикуляції» [6]. Певної мірою до дітей можна прирівняти й слухачів мовного курсу української мови як іноземної. Певним чином ці процеси схожі: коли діти тільки починають засвоювати рідну мову, таким чином її починають опановувати іноземці-початківці. Вимовляння скоромовок не тільки розвиває артикуляцію, але й впливає на вироблення культури мовлення. На це звертали увагу українські дослідники дитячих паремій Г. В. Довженок, К. М. Луганська, Л. М Кіліченко, 3.Б.Лановик, М. Б. Лановик та ін.

Видатний хоровий диригент, педагог Микола Петрович Вішленков зазначає: «Практичний досвід роботи протягом більше двадцяти років художнім керівником та диригентом хору хлопчиків і юнаків «Азъ і Буки» Харківського національного академічного театру опери та балету і старшого хору в ДМШ № 11 засвідчив, що велика кількість дітей мають дефекти мовлення (нині і це співвідношення щороку збільшується)» [1].

На думку цього педагога існує декілька причин такої ситуації:

«- соціально-економічні умови та сучасний, напружений темп життя не надають можливості батькам повною мірою виховувати дітей удома;

- недостатня кількість дошкільних установ і перевантаженість класів у загальноосвітніх школах не дозволяють приділяти належної уваги кожній дитині;

- засоби масової комунікації, які транслюють дитячі програми, зокрема зарубіжні мультиплікаційні фільми сумнівної якості, нерідко спрямовані на образно-сюжетне, інформаційне сприйняття персонажа чи події. Таким чином, дитина не завжди має можливість [...] правильно вимовляти ті чи інші тексти, отже, розвивати свою дикцію;

- нині спілкування змістилося зі сфери «живого» мовлення у віртуальну площину, тому діти, а особливо підлітки, не приділяють належної уваги своїй вимові» [1].

Правильна і чітка вимова, дикція (від лат. dictio - вимова) - це, як свого часу визначив Коклен-старший, «ввічливість актора». Як зазначає Вікіпедія, «чітке вимовляння звуків відповідно до фонетичних норм мови, виразність дикції - важлива сторона майстерності актора, співака, промовця» [4]. I, на нашу думку, не тільки актора чи співака, а й будь-якої ввічливої людини, яка дбає про те, щоб іiі правильно й без зайвого напруження розуміли ті, хто іiі слухає.

За словами М.П. Вішленкова, «час зародження скоромовок точно не визначений. Радше за все вони виникли ще в первісну епоху з культовою метою $\mathrm{i}$ 
призначалися для здійснення ритуалів як своєрідних магічних заклинань. У стародавніх культурах їх могли використовувати для розваги в процесі святкових дій і спільного співу, тому вони належать до народного фольклору» [1].

М.П. Вішленков зазначає, що «одним із перших дослідників народної творчості, хто зацікавився цим жанром, був В. І. Даль, який уперше опублікував зібрання скоромовок (49 текстів) у «Прислів'ях російського народу» в 1862 р. Саме цей науковець першим увів до наукового обігу народний термін «скоромовки» i надав таке визначення: «Частоговорка, чистоговорка, род складной речи, с повтореньем и перестановкой одних и тех же букв или слогов, сбивчивых или трудных для произношенья» [1].

На початку XX ст. в різних виданнях оригінальні скоромовки подав найбільший знавець дореволюційного фольклору Прикам'я (Росія) - В. Серебренніков. У другій половині ХХ ст. активно збирали скоромовки В. Анікін, А. Разумов, М. Булатов, Н. Колпакова, А. Анісімова, В. Бірюков, М. Новицька, I. Фрідріх, а особливо плідно - Г. Науменко, упорядник великої фольклорної збірки, куди ввійшли тільки скоромовки: «Тридцять три Сгорки» [1].

Хоча скоромовки й мають досить давню історію, але наукових досліджень цього фольклорного явища майже немає. Але відомо, що «записи, здійснені фольклористами в другій половині XIX - початку XX ст., свідчать про те, що дорослі поступово втратили інтерес до скоромовки, але використовують їх 3 педагогічною метою, зокрема під час роботи 3 дітьми. Завдання скоромовки - у захоплюючій формі навчити чистоти вимови складних звуків, слів і фраз, сприяти подоланню недоліків вимовляння, розвитку почуття мови, чіткої дикції, яка необхідна кожній людині» [1].

Отже, правильно поставлена українська вимова першою відчиняє інокомунікантам двері в українську ментальність, в українську культуру. Відома новаторка в галузі англійської мови Тамара Леонідівна Сірик наголошувала, що саме 3 чіткої вимови кожного звуку чужої мови починається входження в егрегор цієї мови. Вона досліджувала особливості дії обох півкуль головного мозку, їхню співпрацю і дійшла висновку, що для гарного запам'ятовування лексики й граматичних конструкцій людині треба все проговорювати уголос. Людина має для запам’ятовування вимовити лексичну одиницю 21 раз.

К. С. Станіславський, який «починав свою артистичну кар'єру як оперний співак, акцентував на значенні скоромовок для розвитку дикції. Про їхню роль він писав у «Роботі актора над собою», де зазначав, що систематичне й багаторазове повторення одних і тих же самих слів сприяє розвиткові мовного апарату. У результаті цього виробляється здатність відтворювати навіть складні мовні конструкції в найшвидшому темпі» [1].

Опановуючи вимову, іноземці з різних країн зіштовхуються з труднощами. У кожного мовця ці труднощі свої. Кожна людина має свої мнемотехнічні здібності, а в представників того чи іншого народу є ще й свої особливості, в залежності від того, до утворення яких звуків прилаштувався з дитинства мовний апарат представників конкретного етносу - носія тієї чи іншої мови.

Відомо, що індійцям важко дається звук «ж» і для декого 3 них - «з», а також нерідко звук «х», який багато 3 них відтворюють як «кх». У фран- 
комовних камерунців та алжирців - нерідко виникають проблеми зі звуками «р» чи твердого «л», які вони вимовляють як «ль», «Л мяке».

Часто іноземцям важко розрізняти звуки «Х», «Г» і «Г». Голосна «и» важко дається майже всім іноземцям. Йотовані «є», «ї», «ю» та «я» теж потребують додаткових зусиль для набуття мовної компетенції. Звуки «шча», якими ми читаємо літеру «щ» теж даються інокомунікантам не одразу. У багатьох слухачів теж викликає труднощі опозиція «з - с». Також ми шліфуємо на практикумі з української мови вимовляння буквосполучень «дж» $\mathrm{i}$ «з» або «бг» і «пх». Звертаємо увагу і на вимову слів із апострофом.

На онлайн-заняттях чи на парі в аудиторії робимо так: після ознайомлення 3 новою літерою, яка позначає один чи два звуки, переходимо до доведення правильної вимови звуку в різних позиціях, у різному звуковому оточенні. У цьому допомагає нам скоромовка, стисла римовка, віршик або прислів'я.

Працюючи над скоромовкою, не забуваємо про алгоритм роботи:

1. Спершу повільно прочитати скоромовку.

2. Добитися того, щоб студенти знали значення кожного слова у скоромовці. Не повторювали слова бездумно й несвідомо.

3. Спонукати спершу читати повільно, але без помилок.

4. Запропонувати читати скоромовку швидше за умови, що кожен звук слухачі вже вимовляють добре.

Часто трапляється так, що група складається зі слухачів різного рівня володіння українською фонетикою. Тоді треба для надання правильного зразка іншим студентам групи спершу давати можливість читати більш встигаючим студентам. Слабкіші у навчанні студенти мають можливість почути прочитану скоромовку від своїх товаришів.

Римована мова у скоромовці чи прислів’і полегшує працю і робить цікавішим запам'ятовування слів чи речень. Часто скоромовка носить гумористичний характер. Інколи вона виглядає як перевертень чи нісенітниця. Цим вона розважає, підбадьорює слухачів, робить емоційну розрядку на занятті.

За словами М. П. Вішленкова, «розрізняють скоромовки короткі та довгі, римовані й неримовані, сюжетні і безсюжетні, логічні й абсурдні, з повторами i без них, «побудовані» на одному звуці й на сполученнях звуків, доступні дитячому сприйняттю i не передбачені для цього. Не всі жанри літератури мають таке різноманіття, як скоромовки» [1].

Іноді ту чи іншу відшукану в Інтернеті скоромовку ми дещо перероблюємо, щоб покращити або їі ритміку, або зміст. Наведемо декілька прикладів таких перероблених нами скоромовок:

Ма́ша, Лїна та Мари́на ми́ттю з 'ї́ли всю мали́ну. (звуки [м, л, р])

Малюва́в мале́нький Мі́ша ма́слом ми́лу сі́ру ми́шу. (звуки [м, л, р, ш])

Шу́ра ши́лом шубку зши́ла. В шу́бизі Шу́ра як шинши́ла. (звук [ш])

У новорічну ніч пан Носорі́ нами́сто начепи́в на ріг. (звуки [н, ч, p])

Тигреня́тко з ти́гром-та́том тренува́лися стриба́ти. (звуки [т, г, р]) 
Túxо тра́ктор торохти́ть - ті́льки трактори́ст мовчи́ть. (звуки $[\mathrm{T}, \mathrm{x}, \mathrm{p}]$ )

Дим дими́ть із димаря́, дзвін дзвени́ть у дзвонаря́. (звуки [д, Дз])

В їжаків є їжача́та, у вужі́в є вуженя́та. (звуки [ж, в])

Жук у жи́ті зажури́вся, жва́вий джміль десь забари́вся. (звуки [ж, дж])

Дід Жера́р лежа́в у лі́жку $і$ чита́в про Жа́нну кни́жку. (звук [ж]) (пор. першопочаткове «Жвавий дід смалив у ліжку і читав цікаву книжку») [11].

Боро́м брів бобе́р до бра́та бо́рошна собі набра́ти. (звуки $[б, \mathrm{p}])$

Зазначимо, що важливо також опрацювати правильне наголошування слів у скоромовці. 3 цією метою у процесі підготовки до заняття ми розставляємо наголоси у підібраних нами на певні звуки словах і реченнях, використовуючи так звані «гарячі» (або «швидкі) клавіші.

Розповімо, як це можна зробити технічно. Ми друкуємо слово до потрібної літери (включно), над якою необхідно поставити наголос (чи можна надрукувати слово повністю, а потім поставити курсор після потрібної букви). Потім набираємо на цифровій панелі Num Lock (або на верхніх цифрових клавішах) цифри 0300 (наголос зліва направо) або 0301 (наголос справа наліво) и натискаємо комбінацію клавіш лівого Alt (цю клавішу треба натиснути першою і утримати іiі) і X (латинську). Після цього клавіші відпускаєте і над потрібною буквою з'явиться значок наголосу.

Ще один спосіб поставити наголос над потрібною літерою: натискаєте лівий Alt i правою рукою на панелі Num Lock набираєте цифри 769. Після цього відпускаєте клавішу Alt i з'являється наголос справа наліво. Цифри 768 дають наголос зліва направо, як, наприклад, у болгарській мові.

Звісно, можна вставляти деякі наголошені голосні, вибираючи їх iз віконця «Символ». Але, по перше, це трохи довше, ніж через гарячі клавіші, а, по-друге, якщо ми роздруковуємо потрібний файл з іншого пристрою, то, як показала практика, іноді трапляється, що використання різних версій Ворда чи різних моделей принтерів можуть привести, що замість цього символу друкується прямокутничок.

Гарячі клавіші можуть допомагати швидко ставити апостроф, якщо його немає на клавіатурі. Цей знак дає комбінація клавіш Alt + 0146 (символ «+» при цьому не набирається, він тут позначає, що до клавіші Alt додаються ще дані цифри).

Комбінація Alt + 0150 дає на виході знак «тире».

Літера «Г» можна швидко поставити таким чином: Alt + $0165-$ Г; Alt + 0180 - г. Ще один варіант для цієї літери: натиснути праву клавішу Alt $\mathrm{i}$ клавішу «Г» - для маленької «Г», або лівою рукою натискаємо Shift, а правою Alt i клавішу «Г» - для великої «Г». При певних навиках усе це можна зробити $\mathrm{i}$ однією правою рукою, використовуючи праву клавішу Shift

Гарячі клавіші дозволяють також набирати українські літери, якщо вам 3 певних причин доводиться набирати україномовний текст на комп'ютері, де не інстальовано українську клавіатуру:

$$
\begin{aligned}
& \text { Alt }+0175-\ddot{\mathbf{I}} ; \text { Alt }+0191-\ddot{\mathbf{i}} ; \\
& \text { Alt }+0170-\mathbf{C} ; \text { Alt }+0186-\mathbf{\epsilon} ;
\end{aligned}
$$


Alt $+0178-\mathbf{I} ;$ Alt $+0179-\mathbf{i}$

Alt $+0165-\mathbf{I} ;$ Alt $+0180-\mathbf{r}$.

Якщо ж треба набрати на українській клавіатурі російський «твердий знак», то допоможе комбінація Alt $+0250-\mathbf{b}$.

Alt +012 - дає розрив сторінки, a Alt + 026 - стрілку зліва направо.

Комбінація Shift + F12 дозволяє зберегти поточний файл.

Чимало функцій кодуються через клавішу Ctrl та одну із клавіш, яка на англійській розкладці має літеру, яка зазвичай співпадає з першою літерою у відповідному англійському слові, що позначає цю функцію. Так, англ. клавіша «A» означає all («все»), «С» - copy («копіювати»), « $\mathrm{F} »-$ found («знайти»), «В bold («жирний»), «I»- italics («курсив»), «О»- open («відкрити»), «Р»-print («друкувати») тощо.

Наведемо приклади таких функцій:

$\mathrm{Ctrl}+\mathrm{A}$ - виділити все (увесь текст у цьому файлі);

$\mathrm{Ctrl}+\mathrm{Z}$ - один крок назад, відміна останньої дії;

$\mathrm{Ctrl}+\mathrm{X}$ - вирізати виділений фрагмент;

$\mathrm{Ctrl}+\mathrm{C}$ - копіювати виділений фрагмент;

$\mathrm{Ctrl}+\mathrm{V}$ - вставити скопійований фрагмент;

$\mathrm{Ctrl}+\mathrm{B}$ - виділити напівжирним (той уривок тексту, який перед изим був виділений; якще ж просто натиснути Ctrl $+B$, то він робить жирним лише те слово, на якому стоїть курсор. Те ж саме стосується $і$ операцій з курсивом $i$ підкреслюванням);

$\mathrm{Ctrl}+$ I - курсив; Ctrl + U - підкреслення;

$\mathrm{Ctrl}+\mathrm{N}-$ створити новий файл;

$\mathrm{Ctrl}+\mathrm{D}$ - викликати панель шрифтів;

$\mathrm{Ctrl}+\mathrm{F}$ - пошук через ключове слово;

$\mathrm{Ctrl}+\mathrm{G}$ - замінити, знайти, перейти;

$\mathrm{Ctrl}+\mathrm{H}$ - замінити (наприклад, 2 пробіли на один); у верхнє віконце вставляємо той символ, який треба замінити, у нижній - на який заміняємо;

$\mathrm{Ctrl}+\mathrm{L}$ - вирівнювання тексту по лівому краю

$\mathrm{Ctrl}+\mathrm{R}$ - вирівнювання по правому краю

$\mathrm{Ctrl}+\mathrm{E}$ - вирівнювання по центру;

$\mathrm{Ctrl}+\mathrm{J}$ - вирівнювання по ширині;

$\mathrm{Ctrl}+\mathrm{O}$ - відкрити ще один файл;

$\mathrm{Ctrl}+\mathrm{P}$ - відправка документа на друк на принтер;

$\mathrm{Ctrl}+\mathrm{T}$ - здвинути нижній «флажок» абзацу вправо [10].

Ще декілька корисних функцій із швидкими клавішами.

Shift + F3 - робить зміну регістру букв. Слово, на якому стоїть курсор, переключення цих клавіш спочатку робить із великої літери (при першому натисканні на F3), а потім робить усі літери великими - якщо натиснути другий раз. Якщо слово (чи шматок тексту) набране великими літерами, а треба їх зробити малими - то виділяйте цей фрагмент, а тоді Shift + F3 [3]. 
Ctrl + Shift + Пробіл - дає безперервний пробіл (якщо не бажано розривати скорочення на різні рядки: прізвище та ініціали; число і скорочення (кг., г., р., год. тощо).

$\mathrm{Ctrl}+\rightarrow-$ переміщення курсору на одне слово вперед.

$\mathrm{Ctrl}+\leftarrow-$ переміщення курсора на одне слово назад.

$\mathrm{Ctrl}+$ стрілка вгору - переміститися на один абзац угору;

Ctrl + стрілка вниз - переміститися н а один абзац униз [3].

Комбінація Ctrl + Home - дозволяє переміститися в початок документу, а $\mathrm{Ctrl}+$ End - дозволяє переміститися в кінець документа;

Alt + Shift + Стрілка вгору - дає переніс виділених абзаців угору;

$\mathrm{Alt}+\mathrm{Shift}+$ Стрілка вниз - переніс виділених абзаців вниз [10].

Навіть коли наголоси у тексті розставлені, викладачеві варто ще додатково стимулювати студентів-інокомунікантів дотримуватися правил правильного наголошування, запобігати утворення звички вживати ті чи інші слова 3 неправильним наголосом, стежити за гарною вимовою і правильним наголошуванням слів.

Отже, знаючи основні етапи роботи над скоромовками у процесі вивчення фонетики української мови слухачами мовного курсу, викладач може суттєво поліпшити вміння артикулювати, вимовляти інтонувати українською. У процесі підготовки методичних матеріалів для освітнього процесу в умовах онлайн навчання філологам стануть у пригоді технічні знання 3 оформлення правильних наголосів у словах.

\section{Сиисок літератури:}

1. Вішленков М. П. Скоромовки як засіб розвитку вокально-хорової дикції / М. П. Вішленков // Культура України. - 2014. - Вип. 46. - С. 289-295. - Режим доступу: http://nbuv.gov.ua/UJRN/Ku_2014_46_38.

2. Гарячі клавіші - лайфхак для ефективної роботи за ноутбуком / Сайт «Освіторія-медіа» - https://osvitoria.media/experience/garyachi-klavishi-lajfhak -dlya-efektyvnoyi-roboty-za-noutbukom.

3. Горячие клавиши MS Word / https://webmed.irkutsk.ru > doc > pdf > wordkey.

4. Дикція / Вікіпедія. - https://uk.wikipedia.org/wiki/Дикція.

5. Полный список комбинаций клавиш на клавиатуре / Сайт «winper.ru» https://winper.ru/poleznye-stati/2-polnyj-spisok-kombinatsij-klavish.html.

6. Пройшов захід скоромовок-спотиканок «Хто зможе повторити?» / Сайт Бібліотеки Уманського державного педагогічного університету імені Павла Тичини. https://library.udpu.edu.ua/korystuvacham/bibliohid/49-novyny/ 2636-projshov-zakhidskoromovok-spotikanok-khto-zmozhe-povtoriti

7. Скоромовка / Вікіпедія. - https://uk.wikipedia.org/wiki/Скоромовка.

8. Скоромовка / Словник української мови: в 11 тт. / АН УРСР. Інститут мовознавства; за ред. І. К. Білодіда. - К.: Наукова думка, 1970 - 1980. - Т. 9. - С. 301.

9. Скоромовки - логопедичні чистомовки / Сайт закладу дошкільної освіти «Теремок» - https://teremok-sad.inf.ua/storinka-logopeda/17-skoromovki-logopedichni-chistomovki.

10. Сполучення клавіш у Microsoft Word для Windows / Сайт «Генерація успішної дії»https://gud.rv.ua/other/poiednannia-klavish/spoluchennya-klavish-u-microsoft-word-dlya-windows.

11. Турчина Ю. Скоромовки - логопедичні чистомовки / Сайт «Наша парафія» https://parafia.org.ua/dytyacha-storinka/skoromovky-lohope-dychni-chystomovky.

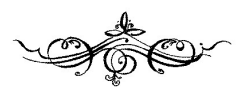


Ольга Дмитрівна Будугай (м. Біла Церква, Україна)

канд. філол. наук, дочент кафедри мовної підготовки Міжнародного

навчально-наукового інвестииійного иентру Білочерківського наџіонального аграрного університету

doi: 10.33245/20-05-2021-25-29

\section{Культурологічний проект «Сім чудес України» як ефективне джерело вивчення лінгвокраїнознавства іноземними громадянами}

Анотація: $У$ статті мова йде про особливості опрацюювання матеріалів про культурологічний проект «Сім чудес Украӥни» у прочесі вивчення інокомунікантами украӥнознавства. Проект дає широкі можливості для формування мовленнєвої компетенції у слухачів курсу украӥнської мови як іноземної на етапі довузівської підготовки.

Ключові слова: украӥнська мова як іноземна, лінгвокраӥнознавство, українознавство, проект «Сім чудес України», культурологія, фонові знання.

The topic: «Cultural project "Seven Wonders of Ukraine» as an effective source for studying linguistics by foreign citizens»

Annotation: The article deals with the peculiarities of processing materials about the culturological project «Seven Wonders of Ukraine» in the process of learning Ukrainian Culture and Lifestyle by foreign communicants. The project provides ample opportunities for the formation of speech competence in students of the Ukrainian language course as a foreign language at the stage of pre-university training.

Key words: Ukrainian as a foreign language, linguistics, Ukrainian studies, project «Seven Wonders of Ukraine», culturology, background knowledge.

Дедалі більше іноземних громадян вибирають Україну для здобуття своєї освіти. Українська мова як іноземна щороку стає ще більш потрібна в освітньому процесі. Щоб опанувати чужу мову, важливо примножувати та систематизувати лінгвокраїнознавчі знання. Державним стандартом України «Українська мова як іноземна. Рівні загального володіння та діагностика» передбачені години на вивчення української мови.

Викладачам української мови як іноземної треба за короткий проміжок часу навчити слухачів основ мови, а також зуміти сформувати поняття про українську ментальність, особливості культури країни, мову якої іноземці опановують. Про це вели мову у своїх працях дослідники О. Гриценко, Л. Даниленко, Т. Дегтярьова, І. Зозуля, І. Ключковська, А. Літвінчук, Д. Мазурик, О. Палінська, О. Пташник, Л. Роман, Ю. Торчинська, О. Туркевич, Б. Сиванич, О. Синчак, Г. Швець та ін.

Освітяни постійно розширюють коло пошуків, прагнуть методично грамотно подати іноземним громадянам фонові знання про мову країни, яку вони вивчають. Мета статті - виявити особливості формування мовленнєвої 
компетенції у слухачів курсів української мови як іноземної на заняттях 3 українознавства, зокрема у процесі опрацювання теми «Культурологічний проект «Сім чудес України».

У серпні 2007 року очільники української культури під орудою відомого громадського діяча Миколи Томенка обрали з немалої кількості культурних пам'яток України сім найбільш вартих уваги. У «Сім чудес України» ввійшли такі об'єкти: фортеця у місті Кам'янець-Подільський, фортеця Хотин у Чернівецькій області, Хортицька Січ у Запоріжжі, парк Софіївка в Умані на Черкащині, КиєвоПечерська лавра в Києві, Собор Святої Софії в Києві, розкопані руїни античного міста Херсонес Таврійський біля міста Севастополя у Криму.

Для прикладу пропонуємо укладений нами текст про Кам'янецьПодільський із завданнями до нього. Цей текст скомпонований нами за допомогою Інтернет-матеріалів та праць дослідників історії Кам'янцяПодільського. Цю перлину української історії та архітектури досліджували в різні періоди історії відомі краєзнавці: В. Бабляк, Л. Баженов, О. Будзей, О. Комарніцький, О. Пламеницька, В. Яблонська та ін.

На нашу думку, запропонований текст можна використати як для читання, так і для аудіювання. До тексту складено завдання різних типів: запитання, упорядкування інформації, тести та інші вправи на засвоєння змісту прочитаного, відтворення інформації, iї творче опрацювання.

\section{Текст}

\section{Фестиваль у місті Кам'янець-Подільський (278 слів)}

Українське місто Кам'янець-Подільський розташоване в Хмельницькій області, недалеко від кордонів Молдови та Румунії. Місто відоме чудовим Національним історико-архітектурним заповідником «Кам'янець». У серпні 2007 року Кам'янець-Подільський був доданий до списку семи чудес України. Це означає, що Кам'янець-Подільський визнано перлиною культури та історії.

Назва фортеці пов'язана зі словом «камінь». Це матеріал, з якого збудована фортеця. Ї̈ї будівництво тривало з XI-го століття до XVI століття. Фортеця - це укріплена фортифікаційна споруда 3 постійним гарнізоном, запасом провіанту та зброї. У фортеці можна перебувати в круговій обороні, захищатися від агресії ворога, пережити облогу.

Острів, на якому розташована ця фортеця, оточений каньйоном. По каньйону тече ріка Смотрич. Тут вона утворює петлю. Ріка Смотрич омиває острів і тече далі. Кам'янецький замок з'єднується з містом вузькою скалою, на якій збудований Замковий міст.

Усі укріплення Кам'янця поділяються на дві категорії. Це замок та міські фортифікації. Сам замок складається 3 двох частин: старого замку з мурами та кількома баштами, нового замку із земляними валами та ровами. Фортеця була збудована до часів появи вогнепальної зброї, тому башти замку та міста були повністю кам'яними. Вони мали кам'яні кронштейни і верхи. Сучасні дахи башт були прилаштовані вже пізніше. 
У старому місті вузенькі та покручені вулиці. $€$ кілька церков XV-го століття. Кожного року в місті проходить фестиваль козаків. Це свято семи різних культур водночас: України, Польщі, Росії, Туреччини, Вірменії, Ізраїлю, Литви. Глядач потрапляє в епоху середніх віків. Спектакль показує життя короля, придворних, лицарів, городян, селян.

Гості міста також беруть участь у виставах, що театралізуються. На святі можна зустріти середньовічних лицарів, польських жовнірів, запорозьких козаків. Минуле тут стає сучасністю.

Туристи можуть піднятися на повітряній кулі або дирижаблі, щоб побачити чудову панораму фестивального Кам'янця-Подільського. Завершується фестиваль яскравим феєрверком.

\section{Завдання до тексту}

\section{1. Дайте відповіді на запитання до тексту.}

1. Де знаходиться місто Кам'янець-Подільський?

2. У якому році Кам'янець-Подільський був доданий до списку семи чудес України?

3. Від якого слова походить назва Національного історико-архітектурного заповідника «Кам'янець»?

4. Що таке фортеця?

5. Яка річка тече по каньйону біля Кам'янецького замку?

6. Чому фестиваль у місті Кам'янець-Подільський називають святом семи різних культур?

7. Що можна побачити глядачам на фестивалі?

8. Чи хотіли б Ви відвідати свято в місті Кам'янець-Подільський?

9. Який подібний фестиваль відзначають у Вашій країні?

2. Розмістіть у правильному порядку пункти плану до тексту «Фестиваль у місті Кам'янець-Подільський».

План

1. Свято семи культур.

2. Завершення фестивалю.

3. Архітектура та укріплення Кам'янця.

4. Українське місто в Хмельницькій області.

\section{3. Закінчіть речення.}

1. Українське місто Кам'янець-Подільський розташоване в Хмельницькій ...

2. Назва фортеці пов'язана зі словом ...

3. По каньйону тече ріка ...

4. У старому місті вузенькі та покручені ... 
5. Глядач на святі потрапляє в епоху середніх ...

6. Завершується фестиваль яскравим ...

\section{4. Виберіть правильну відповідь.}

1. Кам’янець-Подільський знаходиться у ...

А. у Полтавській області.

Б. у Тернопільській області.

В. у Хмельницькій області.

2. Щороку Кам’янець-Подільський збирає гостей на...
А. на фестиваль.
Б. на спортивні змагання.
В. на вибори.

3. Національний історико-архітектурний заповідник у Хмельницькій області називається
А. «Переяслав».
Б. «Запорозька Січ».
В. «Кам'янець».

4. В яку епоху потрапляє глядач на фестивалі в Кам'янці?
А. Глядач потрапляє в античну епоху.
Б. Глядач потрапляє в епоху Відродження.
В. Глядач потрапляє в епоху Середньовіччя.

5. Кого можна зустріти на святі семи культур у Кам'янці?

А. Сучасних прикордонників, повітряних десантників у військовій формі.

Б. Середньовічних лицарів, польських жовнірів, запорозьких козаків.

В. Відомих ветеранів спорту, естрадних співаків, видатних акторів кіно.

Отже, матеріали про культурологічний проект «Сім чудес України» можна плідно застосувати на заняттях 3 інокомунікантами. Слухачі мовного курсу довузівської підготовки пізнають для себе нові цікаві місця на культурній мапі нашої країни, мають можливість глибше зануритися в історію України. Тексти про визначні місця України допомагають засвоїти важливі мовленнєві компетенції у процесі знайомства з українською культурою.

\section{Список літератури:}

1. Державний стандарт України «Українська мова як іноземна». Рівні загального володіння та діагностика / Укладачі: Д. Мазурик (ЛНУ ім. Івана Франка), О. Антонів (ЛНУ ім. Івана Франка, ГО «Центр україністики»), О. Синчак (Український католицький університет), Г. Бойко (НУ «Львівська політехніка», МІОК). 2018.

2. Кам'янець-Подільська фортеця / Вікіпедія. - Код доступу - https://uk. wikipedia. org/wiki/Кам\%27янець-Подільська_фортеця. 
3. Пламеницька O. Castrum Camenecensis. Фортеця Кам'янець (пізньоантичний ранньомодерний час). Наукова монографія. - Кам’янець-Подільський: ФОП Сисин, 2012. $672 \mathrm{c}$.

4. Українська мова як іноземна. Тексти для читання. Практикум для студентів підготовчого відділення / автори: С. Д. Карпенко, Т. М. Рудакова, О. Д. Будугай, І. М. Тимчук, С. Г. Погоріла, Н. Ю. Римар, Ю. А. Чернобров, Н. А. Баран, А. І. Єрко; за ред. С. Д. Карпенко. - Київ. Видавничий дім Дмитра Бураго, 2019. - 256 с.

5. Фестивалі Кам'янця-Подільського / Вікіпедія. - Код доступу - https:// uk.wikipedia.org/wiki/Фестивалі_Кам\%27янця-Подільського.

6. Яблонська Д. Олег Будзей - відомий сучасний краєзнавець Кам'янця-Подільського // Сайт «Кам'янець-Подільський історичний»: матеріали конкурсу учнівських і студентських робіт. Випуск III. - Кам’янець-Подільський, 2011. - С. 38-42.

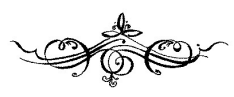

УДК 378.147.096:004.774

Лідія Прокопівна Гайдук (м. Запоріжжя, Україна), старший викладач Центру підготовки іноземних громадян Запорізького державного медичного університету; Наталія Валентинівна Гроссу (м. Запоріжжя, Україна), викладач Центру підготовки іноземних громадян Запорізького державного медичного університету

doi: 10.33245/20-05-2021-29-31

\section{Онлайн-курс як засіб організації самостійної роботи студентів довузівського етапу підготовки}

Анотація: У статті автори розповідають про досвід впровадження в навчальний прочес онлайн курсу «Читаємо $і$ говоримо украӥнською мовою» $з$ метою організаиії самостійної роботи студентів довузівського етапу підготовки.

Онлайн-курс було створено викладачами Центру підготовки іноземних громадян Запорізького державного медичного університету на платформі еdX, яка забезпечує організацію $i$ здійснення освітнього процесу від постановки мети до проведення підсумкового контролю.

Ключові слова: онлайн курс, самостійна робота студентів, украӥнська мова, довузівська підготовка, платформа еdX.

The topic: "Online course as a means of organizing the independent work of students of the pre-university stage of preparation"

Abstract: In the article, the authors talk about the experience of implementing an online course "Reading and speaking Ukrainian» in order to organize independent work of students of the pre-university stage of preparation. 
The online course was created by teachers of the Center for Training of Foreign Citizens of Zaporizhia State Medical University on the edX platform, which provides the organization and implementation of the educational process from goal setting to final control.

Key words: online course, independent work of students, Ukrainian language, preuniversity training, edX platform.

One of the most important tasks of modern pre-university education is the formation of a person capable of self-development, to self-study of educational material. The solution of this problem is possible by introducing into the educational process new forms and technologies of learning, adequate to the current level of technical capabilities.

Online courses are an effective tool for organizing independent work of students at Zaporizhia State Medical University. The creation of online courses is satisfied by the edX platform [1] which provides the organization and implementation of the educational process from goal setting to the final control. EdX is a joint nonprofit company of the Massachusetts Institute of Technology and Harvard University to provide online courses from world-renowned freelancers.

The edX website was originally filled only with MITx and Harvardx materials, but now other universities have the opportunity to join the platform and create their own online courses. This opportunity was given to Zaporizhia State Medical University, which is part of the edX participants.

Creating online courses in each discipline is one of the priority areas of work of teachers of the Center for Training of Foreign Citizens of ZSMU.

In 2019, an online course for independent work «Reading and speaking Ukrainian» was created [2]. The course is addressed to foreign citizens who study the Ukrainian language at the pre-university stage of study. The materials of the online course were created in accordance with the work program on the subject «Ukrainian language» (ZSMU, 2019). The texts presented in the online course are coordinated with the main textbook of the Ukrainian language.

The purpose of the online course is to develop the skills of reading texts on social issues and skills of participation in dialogue-questioning. All materials are selected taking into account the communicative needs of foreign students in terms of communication in everyday situations.

The online course is designed for 21 hours of remote independent individual work. Each course developed in edX-Studio has the following nesting structure:

1. Section

2. Subsection

3. Units

4. Components

The introduction to the course provides information on the subject of the course, the duration of training, the grading system and the authors of the course.

In the first section, students learn about the purpose and purpose of the course. It also provides information about the knowledge and skills that students must acquire after completing the course: 


\section{Knowledge and skills}

After taking an online course, an international student must know:

- basic lexical minimum of the topic, including synonymy-antonymy;

- verbal control;

- basic communicative types of questions;

- basic models of expressing one's own opinion.

\section{be able:}

- have basic vocabulary and use it adequately in the communication process;

- use lexical-grammatical and stylistic synonymy and antonymy;

- to model monologue expressions with the use of speech models of the lesson;

- build monologue statements: description or message

- confirm or refute the statement.

Subsequent sections correspond to topics that students study independently. For example, section № 2 - Topic № 1 «Class»».

The sections are an annotation and five tasks, three of which are pre-text and one is post-text. Both pre-text and post-text tasks are accompanied by illustrations and tests. The text «Class» is presented as an audio recording and directly as text.

The total number of topics designed for self-study - ten. Completes the online course final test. During the tasks the teacher has the opportunity to track the progress of the student. EdX provides the ability to receive data on student activity and performance throughout the course.

In this way, the edX system will help the teacher to assess the tasks set for students and direct efforts to improve the course and quality of student learning. An important advantage of online courses is that they provide an opportunity to unify the learning process by composing tasks.

In our opinion, the advantage of online courses for students is the ability to remotely receive educational materials and valid information.

Virtual learning environment, specially designed for the creation of online courses by teachers, opens new perspectives for the development of students 'selfeducation, to increase students' motivation to learn.

Foreign students who study the Ukrainian language at the pre-university stage of study have the opportunity to remotely acquire knowledge of the Ukrainian language. Upon completion of the course, they acquire the communication skills and abilities necessary for communication in the socio-cultural and everyday spheres.

1. EdX. Website. URL: https://www.edx.org/

\section{List of references:}

2. Васецька Л. І., Гайдук Л. П., Гроссу Н. В. Читаємо і говоримо українською мовою: сценарій онлайн-курсу для самостійної роботи слухачів - іноземних громадян довузівського етапу підготовки. - Запоріжжя : ЗДМУ, 2019. - 41 с.

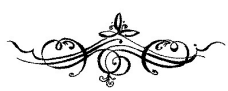


Наталія Олегівна Димань (м. Біла Церква, Україна), асистент кафедри мовної підготовки Міжнародного навчально-наукового інвестиційного цеентру Білоцерківського наџіонального аграрного університету

doi: $10.33245 / 20-05-2021-32-34$

\title{
Метод «синквейн» у практиці викладання української мови як іноземної
}

\begin{abstract}
Анотація: У статті йдеться про можливість використання інтерактивного методу «синквейн» під час викладання украӥнської мови як іноземної. Наведено алгоритм застосування методу і приклади робіт, виконаних слухачами курсу мовної підготовки представниками різних краӥн. Зроблено висновок про ефективність методу синквейну як засобу формування україномовної комунікативної компетентності іноземних студентів.

Ключові слова: інтерактивні методи, «синквейн», комунікативна компетентність, украӥнська мова як іноземна.
\end{abstract}

\section{Natalia Olehivna Dyman}

The topic: «The “cinquain" method in the teaching of Ukrainian as a foreign language»

Abstract: The article deals with the possibility of using the interactive method «cinquain» while teaching Ukrainian as a foreign language. An algorithm of the method application and examples of works performed by the students of the language training course - representatives of different countries are given. A conclusion on the effectiveness of the syn-Queen Method as a means of forming Ukrainian-language communicative competence of foreign students is made.

Key words: interactive methods, "cinquain", communicative competence, Ukrainian as a foreign language.

Основні методичні інновації в освіті сьогодні пов’язані з впровадженням інтерактивних методів навчання. Вони активно інтегрувалися у практику викладання найрізноманітніших дисциплін, у тому числі української мови як іноземної, завдяки спроможності забезпечити високий ступінь активності i самостійності студентів. На думку численних авторів, інтерактивне навчання забезпечує не тільки взаємодію, а й взаєморозуміння і взаємозбагачення.

Серед найчастіше застосовуваних технологій інтерактивного навчання виділяють рольову гру, роботу в малих групах, дебати, «брейнстормінг», метод проектів [3, 4]. На жаль, такий метод як «синквейн» не набув широкого використання у вищій школі, тимчасом активно практикується для мовленнєвого розвитку дошкільників [1].

Мета нашої роботи - продемонструвати застосування методу «синквейн» під час викладання української мови як іноземної, який було успішно апробовано на курсі мовної підготовки іноземних студентів у Білоцерківському національному аграрному університеті по завершенню 4 місяців навчання. 
Синквейн (від франц. cinq - п'ять) - це п’ятирядкова віршована форма, яка виникла в США на початку 20 століття. Ї̈̈ придумала американська поетеса Аделаїда Крепс під впливом популярної на той час японської поезії. У подальшому іiі стали широко використовувати у багатьох країнах світу 3 дидактичною метою як метод розвитку виразної мови, інтелектуальних та аналітичних здібностей, що уможливлює отримання швидкого результату навчання [3].

Синквейн має таку структуру:

1-й рядок - одне слово (зазвичай іменник чи займенник), яким задається тема синквейну;

2-й рядок - опис ознак і властивостей іменника (зазвичай 2 прикметника);

3-й рядок - опис дії, яку виконує іменник (зазвичай 3 дієслова);

4-й рядок - фраза (зазвичай із 4-х слів, що належать до різних частин мов), яка розкриває ставлення автора до іменника;

5-й рядок - синонім до слова, яке визначає тему.

Можливі різні варіанти застосування синквейну [2, 3], метод прийнятний за різних форм навчання - денної, дистанційної та змішаної.

Нами використано такий алгоритм:

1) на початку заняття викладач знайомить студентів з методом синквейну і пояснює правила виконання завдань;

2) студентам надається 10 хвилин для складання синквейну;

3) студенти обмінюються своїми варіантами і вибирають найвдаліший, на ї думку;

4) студенти презентують свою роботу.

У таблиці 1 наведено приклади, складені іноземними студентами різних країн, які вивчають українську мову як іноземну.

Таблиия 1.

Приклади складання синквейнів студентами-іноземцями із різних країн

\begin{tabular}{|c|c|c|c|}
\hline \multirow{2}{*}{ Країна } & \multicolumn{3}{|c|}{ Синквейн } \\
\hline & 1 & 2 & 3 \\
\hline Індія & $\begin{array}{l}\text { 1. Річка } \\
\text { 2. Велика, широка } \\
\text { 3. Текти, плавати, } \\
\text { митися } \\
\text { 4. У річці багато риби } \\
\text { 5. Вода }\end{array}$ & $\begin{array}{l}\text { 1. Університет } \\
\text { 2. Гарний, великий } \\
\text { 3. Учити, говорити, читати } \\
\text { 4. В університеті багато } \\
\text { аудиторій } \\
\text { 5. Школа }\end{array}$ & $\begin{array}{l}\text { 1. Церква } \\
\text { 2. Біла, красива } \\
\text { 3. Молитися, просити, } \\
\text { вірити } \\
\text { 4. Я йду до церкви просити } \\
\text { щастя } \\
\text { 5. Будинок } \\
\end{array}$ \\
\hline Камерун & $\begin{array}{l}\text { 1. Річка } \\
\text { 2. Чиста, глибока } \\
\text { 3. Плавати, пити, } \\
\text { жити } \\
\text { 4. Біля річки я } \\
\text { відпочиваю } \\
\text { 5. Море }\end{array}$ & $\begin{array}{l}\text { 1. Університет } \\
\text { 2. Аграрний, світлий } \\
\text { 3. Знати, уміти, говорити } \\
\text { 4. В університеті я маю багато } \\
\text { друзів } \\
\text { 5. Школа }\end{array}$ & $\begin{array}{l}\text { 1. Церква } \\
\text { 2. Свята, чиста } \\
\text { 3. Плакати, молитися, } \\
\text { любити } \\
\text { 4. Моя душа тут має спокій } \\
\text { 5. Притулок }\end{array}$ \\
\hline
\end{tabular}


Аналізуючи дані таблиці 1, можна помітити деякі відмінності у сприйнятті представниками різних країн навколишнього світу: відповіді студентів із африканського континенту більш емоційно наповнені, у відповідях студентів 3 Індії більше утилітарності.

Метод можна успішно поєднувати 3 іншими технологіями як традиційного, так i інтерактивного навчання - фонетичними та граматичними вправами, рольовими іграми, презентаціями тощо. Його застосування сприяє створенню позитивної комфортної творчої обстановки на занятті, що дає змогу подолати бар'єр страху говоріння іноземною мовою.

Отже, застосування методу «синквейн» робить процес навчання пізнавальним, цікавішим і захопливим, сприяє швидшому засвоєнню тематичної лексики і цим підвищує мотивацію вивчати українську мову в іноземних студентів.

\section{Список літератури:}

1. Використання технології «Сінквейн» в роботі з розвитку мовлення дошкільнят. URL: https://schkola4kotovo.ru/uk/primery-zanyatii-po-dostupnomu -obyasneniyu-sinkveinadoshkolnikami/

2. Гурєєва Л. В., Козьміна Н. А. Синквейн - прийом активізації пізнавального процесу студентів немовних BH3. URL:http://interconf.fi.kpi.ua/node/12573.

3. Мелькаева Р. В., Радин А. М. Интерактивные методы обучения английскому языку // Международный научный журнал «Символ науки». - 2017. - № 12. - С. 147-148.

4. Овдіюк В. В. Новітні інтерактивні технології у практиці викладання української мови як іноземної // Викладання мов у вищих навчальних закладах освіти на сучасному етапі. Міжпредметні зв'язки. - 2017. - Вип. 30. - С. 110-120.

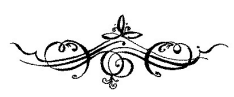

УДК $161.2+378.74$

Ірина Мирославівна Захарків (м. Тернопіль, Україна), спеціаліст вищої категорії, викладач-методист Відокремленого структурного підрозділу «Тернопільський фаховий коледж Тернопільського національного технічного університету імені Івана Пулюя»

\section{doi: $10.33245 / 20-05-2021-34-36$}

\section{Переваги застосування лінгвокраїнознавчого підходу у викладанні української мови як іноземної}

Анотація: Стаття присвячена короткому огляду переваг застосування лінгвокраӥнознавчого підходу у викладанні украӥнської мови як іноземної. Висвітлено, щяо знання іноземними студентами культури, історії, соціально-політичного устрою, традицій $i$ звичаїв Украӥни, формують у них лінгвокраїнознавчу компетенцію, яка генерує 
комунікативну компетенцію мовия, щзо сприяє зближенню, розумінню та залученню до діалогу представників різних культур.

Підсумовано, щчо застосування лінгвокраїнознавчого підходу у процесі викладання украӥнської мови як іноземної сприяе підвищенню мотивації вивчення мови студентами, активізує та полегшує навчальний процес, формує позитивне ставлення до іншої культури, мови та звичаїв, щзо значно покращує міжкультурну комунікацію.

Ключові слова: лінгвокраӥнознавчий підхід, украӥнська мова як іноземна, методика викладання іноземної мови, комунікативна компетенція, студенти-іноземні громадяни.

The topic: «Benefits of applying the lingvocountrystuding approach in teaching the Ukrainian language as a foreign language»

Abstract: The article is devoted to a brief overview of the advantages of using the lingvocountrystuding approach in teaching Ukrainian as a foreign language. It is highlighted that the knowledge of foreign students of culture, history, socio-political system, traditions and customs of Ukraine, form in them linguistic competence, which generates communicative competence of the speaker, which promotes rapprochement, understanding and involvement in dialogue of different cultures.

It is concluded that the application of the linguistic approach in the process of teaching Ukrainian as a foreign language helps to increase the motivation of students to learn the language, activates and facilitates the learning process, forms a positive attitude towards other cultures, languages and customs, which significantly improves intercultural communication.

Key words: lingvocountystuding approach, Ukrainian language as a foreign language, methods of teaching a foreign language, communicative competence, students-foreign citizens.

Мова завжди була тим джерелом, який упродовж тисячоліть акумулював у собі всі прояви та феномени буття етносу. Саме у мові зберігається інформація про історію, звичаї, традиції матеріальної культури й духовного життя нації, тобто знання соціокультурного фону. Занурення у соціокультурний фон країни, мова якої вивчається, сприяє формуванню лінгвокраїнознавчої компетенції. Зазначена компетенція генерує комунікативну компетенцію мовця, яка необхідна йому для успішної міжкультурної комунікації в іншомовному середовищі.

Засвоєння фонових знань (загальнолюдські, регіональні відомості, а також культурознавчі) відповідно до стандартів навчання, викладених у «Загальноєвропейських Рекомендаціях з мовної освіти: вивчення, викладання, оцінювання», актуалізує проблему оптимізації та інтенсифікації процесу підготовки іноземних студентів у вищих навчальних закладах України [4].

Проблема формування лінгвокраїнознавчої компетенції стала предметом дослідження багатьох науковців, методистів, викладачів (В. Бадер, Г. Максименко, Г. Онкович, О. Палка, С. Пілішек, Г. Савицька та ін.). У своїх працях вони слушно відзначають актуальність та важливість застосування лінгвокраїнознавчого підходу у формуванні комунікативної компетенції.

На практиці при викладанні української мови як іноземної із застосуванням лінгвокраїнознавчого підходу було зазначено, що знання іноземними студентами культури, історії, соціально-політичного устрою, традицій і звичаїв 
України сприяє зближенню, розумінню та залученню до діалогу представників різних культур.

Знання студентами норм і цінностей, притаманних культурі українського народу, позитивно впливає на формування особистісних якостей поведінки, культури усного і писемного мовлення, необхідних для успішного спілкування в міжкультурному середовищі. Викладач не тільки навчає іноземного студента української мови, не тільки викладає інформацію про країну, щоб він ії вивчив, але й формує в нього позитивне ставлення до народу - носія мови, адже вивчення мов починається 3 метою зближення та розуміння представників різних народів.

Вдале і продумане залучення лінгвокраїнознавчих матеріалів (історичні тексти, легенди, вірші, приказки, прислів'я, пісні тощо) значно урізноманітнює та збагачує процес навчання, вносить емоційну складову, що мотивує студентів до вивчення мови. Лінгвокраїнознавчий підхід формує позитивне ставлення до вивчення української мови студентами-іноземцями, що у свою чергу сприяє активізації навчального процесу й успішному засвоєнню навчального матеріалу.

Узагальнюючи все вищесказане, можемо відзначити, що застосування лінгвокраїнознавчого підходу у процесі викладання української мови як іноземної сприяє підвищенню мотивації вивчення мови студентами-іноземцями, активізує та полегшує навчальний процес і формує позитивне ставлення до іншої культури, мови та звичаїв, що значно покращує міжкультурну комунікацію.

\section{Список літератури:}

1. Бадер В. І. Функціонально-стилістичний підхід у формуванні лінгвоукраїнознавчої компетентності іноземних студентів // Засоби навчання та науково-дослідної роботи: зб. наук, праць. - Харків: ХНПУ ім. Г.С. Сковороди, 2008. - № 28.

2. Борисенко М. К. Некоторые аспекты преподавания элементов лингвострановедения на французском языке // Иностранные языки в школе. 1997. - № 3. - С. 41-45.

3. Бронська А. Лінгвокраїнознавчий аспект у викладанні української мови як іноземної // Дивослово. - 2000. - № 7. - С. 43-44.

4. Загальноєвропейські Рекомендації 3 мовної освіти: вивчення, викладання, оцінювання. - К., 2003.

5. Максименко Г. А. Застосування лінгвокраїнознавчих матеріалів у викладанні української мови як іноземної // Філологічні студії: Наук, вісник Криворізького держ. пед. ун-ту: зб. наук, праць. - Вип. 1. - Кривий Ріг: Видавничий дім, 2012. - 170 с.

6. Пілішек С. Психосемантичні особливості лінгвокраїнознавства при вивченні іноземної мови у ВНЗ: автореф. дис. на здобуття наук, ступеня канд. психол. наук: спец. 19.00.07 - Хмельницький, 2006. - 20 с.

7. Смолінська О. Лінгвокраїнознавство у навчанні української мови як іноземної // Рідна школа. - 2002. - № 2. - С. 43-45.

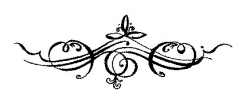


Ірина Свгеніївна Зозуля (м. Вінниця, Україна), канд. педагогічних наук, доцент кафедри мовознавства Вінницького національного технічного університету

doi: $10.33245 / 20-05-2021-37-39$

\section{Розвиток іншомовної дискурсивної компетенції іноземних студентів}

Анотація: $У$ статті розглянуто проблему формування іншомовної дискурсивної компетенщії студентів вищої школи в прочесі навчання украӥнській мові як іноземній. Обгрунтовано важливість розвитку різноманітних підходів щзодо проблеми іншомовної підготовки майбутніх фахівців технічної сфери в умовах освітнього середовища університету.

Зазначено, щзо навчання іноземній мові повинно відбуватися в межах особистісноорієнтованого, комунікативно спрямованого і професійно-діяльнісного підходів у системі мовної професійно-орієнтованої підготовки студентів за умови впровадження в освітній прочес інновачійних технологій навчання украӥнській мові як іноземній. Доведено, щэо ефективність навчання монологічному мовленню як типу дискурсу залежить в першу чергу від рівня сформованості дискурсивної компетентності студентів.

Ключові слова: дискурсивна компетениія, українська мова як іноземна, іноземний студент, міжкультурна компетентність, метод навчання,. students»

The topic: "Development of foreign language discursive competence of international

Abstract: The problem of formation of foreign language discursive competence of high school students in the process of learning Ukrainian as a foreign language is considered in the article. The importance of the development of various approaches to the problem of foreign language training of future specialists in the technical field in the educational environment of the university is substantiated.

It is noted that foreign language teaching should take place within the personality-oriented, communicatively oriented and professional-activity approaches in the system of language professionally oriented training of students under the condition of introduction of the innovative technologies of teaching Ukrainian as a foreign language in the educational process. It is proved that the effectiveness of teaching monologue speech as a type of discourse depends first of all on the level of formation of discursive competence of students.

Key words: discursive competence, Ukrainian as a foreign language, foreign student, intercultural competence, teaching method.

Іншомовна освіта іноземних студентів в Україні спрямована на формування професійно-орієнтованої міжкультурної компетентності як складника діяльнісної компетентності, яка є багатокомпонентним утворенням і включає, поряд з іншими складовими, дискурсивну компетенцію.

Загальноєвропейські рекомендації з мовної освіти визначають основні напрями підготовки студентів ЗВО як майбутніх фахівців, що передбачає досягнення студентами достатнього рівня іншомовної комунікативної компетенції у сферах загальної та професійної комунікації [3, с. 24]. 
Роль сучасних методів у практиці викладання іноземцям української мови продовжує залишатися досить важливою. Головним завданням навчання, як зазначають дослідники $[2,4,5], \epsilon$ практичне володіння розвиненою професійно орієнтованою комунікативною компетенцією для активного застосування української мови в діловому спілкуванні. Тобто, варто шукати такі універсальні підходи для вивчення української мови як іноземної, які б дозволили досягти більш високого рівня підготовки фахівців завдяки інтеграції мовної i професійної сфер.

Дискурсивна компетенція має на меті навчити іноземного студента застосовувати певні стратегії з метою конструювання та інтерпретації тексту. До змісту дискурсивної компетенції відносять розгляд специфікації письмових і усних типів текстів і тактик мовленнєвої поведінки [1].

Ми вважаємо, що навчанню дискурсу має передувати відбір типів дискурсу, які відповідають меті навчання української мови як іноземної в конкретному закладі вищої освіти на основі принципу відбору, базованому на відповідності сферам й ситуаціям спілкування, типовим для конкретної спеціальності.

Саме тому поняття дискурсивної та комунікативної компетенцій тісно пов'язані між собою. Комунікативна компетенція, на нашу думку, є однією 3 найважливіших компетенцій для іноземного студента, недаремно іiі характеризують як інтегративний особистісний ресурс, що забезпечує успішність комунікативної діяльності.

Серед чотирьох видів мовленнєвої діяльності в іншомовній освіті майбутніх інженерів та менеджерів особливу увагу приділяємо навчанню усного монологічного мовлення. Варто сказати, що іншомовна дискурсивна компетентність забезпечує певний культурний рівень усного й писемного мовлення та невербальної мовленнєвої поведінки.

Для забезпечення ефективності процесу формування іншомовної комунікативної компетентності доцільно розробляти нові методологічні підходи й визначати педагогічні умови їхньої реалізації, над чим сьогодні працюють вітчизняні вчені та педагоги-практики.

Поняття усної іншомовної дискурсивної компетентності майбутнього спеціаліста з урахуванням специфіки професії ми трактуватимемо як здатність фахівця будувати, сприймати та інтерпретувати цілісні монологічні (повідомлення, презентації, доповіді-звіту про наукове дослідження, про експериментальні результати технічної розробки, про виконання технічного завдання дослідження описи, оцінювання, виступи) та діалогічні/полілогічні (дискусії, обговорення, бесіди, інтерв'ю, телефонні розмови) усні дискурси українською мовою відповідно до комунікативного наміру в межах професійноорієнтованого спілкування з урахуванням специфіки їх граматичної організації, взаємозв'язку лінгвістичних факторів та норм мовленнєвого етикету.

Загалом предмет спілкування розглядається нами як фрагмент дійсності, відображений спочатку у письмовому дискурсі (написання доповіді), а потім презентований у вигляді усного дискурсу (виступ 3 доповіддю), які мають 
значимість для автора й включають максимально вичерпну інформацію про цільову аудиторію, умови спілкування, можливі ролі комунікантів [5, с. 265].

Отже, у найновіших дослідженнях іншомовну дискурсивну компетентність тлумачать як необхідний іноземному студентові рівень сформованості досвіду міжособистісної взаємодії, щоб успішно функціонувати в суспільстві з огляду на власні здібності. Формування іншомовної комунікативної компетентності у студентів закладів вищої освіти різних напрямів підготовки на сучасному етапі розвитку світової спільноти необхідно розглядати як обов'язкову складову загальної фахової підготовки.

\section{Список літератури:}

1. Зозуля І. Є., Стадній А. С., Мошнріз М. М. Інфокомунікації, радіоелектроніка та наносистеми на уроках української мови для студентів-іноземців. - Частина 1: навчальний посібник. - Вінниця: ВНТУ, 2019. - 100 с.

2. Зозуля, I. Є., Стадній А. С. Фахові терміни на уроках української мови як іноземної. Збірник наукових праць. Серія: Педагогічні науки. - Випуск LXXVI. - Том 1. - Херсон, 2017. - C. $127-131$.

3. Ніколаєва, С. Ю., Загальноєвропейські Рекомендації з мовної освіти: вивчення, викладання, оцінювання. - К. : Ленвіт, 2003. - С. 24-73.

4. Павелків, К. М., Дистанційне навчання іноземної мови для немовних спеціальностей у вищій школі. Актуальні проблеми філології та методики викладання гуманітарних дисииплін: наукові записки Рівненського держсавного гуманітарного університету: зб. наук. праць. - Рівне: РДГУ, 2015. - С. 94-98.

5. Саєнко, Н. С. Сучасні тенденції іншомовної освіти у вищих технічних навчальних закладах. Збірник наукових пращь «Педагогічна освіта: теорія $і$ практика» Кам'янецьПодільського наиіонального університету ім. Івана Огієнка. - 2011. - № 8. - С. 262-266.

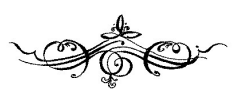

УДК: 94 (497.2)

Йорданов Кристьо (м. Софія, Болгарія), головний асистент, доктор історичних наук, Інститут історичних досліджень Болгарської академії наук (Институт за исторически изследвания - Българска академия на науките)

doi: $10.33245 / 20-05-2021-39-43$

Османсько-турецькі назви видів соколів та яструбів, а також різних видів діяльності, пов'язаних з мисливськими потребами султанського двору та вищих державних службовців в Османській імперії згідно з османськими документами XV-XVI століть

Анотація: У статті розглядаються різні породи соколів $і$ яструбів, а також їх османсько-турещькі назви. На основі опублікованих та неопублікованих османських 
документів подано дані про організаційну структуру соколиного закладу в Османській iмnepiï.

Сокольничі згадуються в османських документах із узагальненими термінами doğancıуan i bazdaran. Сокольничі поділяються на три основні групи - şаhinciyan, çаkırсıуаn u atmacaclyan. Ці три групи відрізняються тим, щуо кожна з них відповідає за вилов, розведення та дресирування різних соколів та яструбів для мисливських потреб султана та його слуг, виступаючи пануючим класом в імперії.

Крім того, за характером своєї служби їх називають ювакаянами $і$ каяк'янами, які спостерігають за гніздами хижих птахів $і$ забирають з них маленьких соколів у певний час року; тузакджаянами, які затримують дорослих хижих птахів; гурентіанами, яі вирощують і навчають уже полонених соколів і яструбів.

Ключові слова: соколи, яструби, назви мисливських птахів, Османська імперія, турецька мова, болгарські соколи.

The topic: "The Ottoman-Turkish names for species of falcons and hawks and various activities related to the hunting needs of the Sultan's court and higher civil servants in the Ottoman Empire according to Ottoman documents of the $15^{\text {th }}-16^{\text {th }}$ centuries»

Abstract: The paper examines the different breeds of falcons and hawks, as well as their Ottoman-Turkish names. Based on published and unpublished Ottoman documents data are presented on the organizational structure of the falconers' institution in the Ottoman Empire. The falconers are named in the Ottoman documents with the generalized terms doganctyan and bazdaran.

The falconers are also divided into the three main falconer groups - şahinciyan, çakurciyan and atmacactyan. These three groups differ in the fact that each of them is responsible for catching, raising and training various falcons and hawks for the hunting needs of the Sultan and his servants acting as the ruling class in the Empire.

But, furthermore, according to the nature of their service they are called yuvactyan and kayaciyan when they observe the nests of the raptors and take the small falcons from them at certain times of the year; Tuzakçlyan who catch adult birds of prey with traps; Gürenciyan, raising and training already captured falcons and hawks.

Key words: falcons, hawks, names of hunting birds, Ottoman Empire, Turkish language, Bulgarian falconers.

Тема: «Османо-турските названия на видовете соколи и ястреби, както и на разнообразните дейности, свързани с ловните нужди на султанския двор и висшите държавни служители в османската империя според османски документи от XV-XVI век»

Резюме: В статията се изследват различните породи соколи и ястреби, както и османско-турските им имена. Въз основа на публикувани и непубликувани османски документи са представени данни за организационната структура на институцията на соколарите в Османската империя. Соколарите са посочени в османските документи с обобщените термини doğancıап и bazdaran.

Соколарите също са разделени на трите основни групи соколари - şаhinciyan, çakırcıуan и atmacacıуan. Тези три групи се различават по това, че всяка от тях е отговорна за улова, отглеждането и обучението на различни соколи и ястреби за ловните нужди на султана и неговите слуги, действащи като управляваща класа в империята.

Освен това, според естеството на тяхната служба те се наричат ювакаян и каякян, когато наблюдават гнездата на грабливите птици и им отнемат малките соколи в определени периоди от годината; Tuzakçıуan, които ловят възрастни грабливи птици с капани; Гюренциян, отглеждайки и обучавайки вече пленени соколи и ястреби.

Ключови думи: соколи, ястреби, имена на ловни птици, Османска империя, турски език, български соколи. 
Ловът с грабливи птици е един от най-старите спортове, при който се използват соколи, ястреби и понякога орли. Различните видове грабливи птици се улавят и дресират за ловни нужди от лица със специални умения, така наречените соколари.

Когато бъдат отгледани малките соколчета и сменят перата си, те се дресират, за да се научат да излитат и кацат отново на ръката на соколаря, който поставя кожени рькавици, за да се предпази от ноктите им. Соколите и ястребите се приучават да ядят от рьката на човека, като обикновено се хранят с гълъби и гризачи. Ловът с ястреби може да се извършва и пеша, но при използването на соколи и орли за ловеца е необходимо да следва ловните птици на кон.

Соколарството съществува от древността. По време на Първото и Второто българско царство (VII-XI; XII-XIV век) ловът със соколи е много популярен сред българската управляваща класа - царят и болярството.

Извори от XIII-XIV в. свидетелстват, че по това време българските царе организирали ловни излети в Предбалкана (северното подножие на Стара планина). Запазените до днес царски грамоти споменават за специална категория служители, които събират отгледаните и дресираните соколи за нуждите на царския лов - така наречените крагуяри (наименованието на професията идва от старобългарската дума за вид сокол - крагуй).

След османо-турското завоевание на България част от българското население продължава да изпълнява соколарската служба, като се отглеждали различни видове грабливи птици вече за ловните нужди на османските султани и другите представители на управляващата класа в Османската империя.

Соколарите в Османската империя са наричани най-общо доганджии или баздари. Първото название произлиза от турската дума doğan (сокол) и наставката за професия - c1 (doğanc1). ${ }^{1}$

Втората дума, също означаваща соколар, е персийска по произход - بازدار (bazdar). ${ }^{2}$ Но в османските документи двете думи, обозначаващи соколарската професия, се използват главно за събирателно назоваване на всички категории соколари.

Османо-турската документация отбелязва съществуването на няколко категории соколари, които се занимават с улавянето, отглеждането и дресировката на точно определени породи соколи и ястреби. Един от предпочитаните за дресиране соколи на турски е наричан чакър (çakır).

Според османо-турските извори онези хора, които улавят и отглеждат тези соколи, живеят в равнините около Пловдив, София и Дунавската равнина. Това е напълно логично, тъй като грабливата птица, която турците наричат чакър (çakır), е от породата малък сокол чучулигар (Falco columbarius). Този сокол обитава откритите полски райони с малки горички, където снежната покривка не се задържа дълго, като избягва високите планини и гъсти гори. Сокольт, който носи турското название доган (doğan), в науката е известен като

\footnotetext{
${ }^{1}$ В съвременния турски наставката за професия е с̧1.

2 باز (сокол, ястреб) и наставка за професия دار (обладавам, държа, пазя).
} 
ловен сокол (Falco cherrug; Falco sacer). Това е същата порода соколи, която се е отглеждала за ловните развлечения на българските царе през XIII - XIV в. и е наричана крагуй.

Много търсени за ловните нужди на османската управляваща върхушка са соколите от породата, назовавана с персийската дума шахин - شاهين (şahin), която в науката е известна като сокол скитник (falco peregrinus). Този сокол обитава скалистите възвишения и редките гори, прошарени с ливади и пасбища, както и в по-високите скалисти планини.

Поради това османските соколарски регистри показват, че хората, улавящи и отглеждащи тази порода соколи, живеят в подножието на Стара планина или в Родопите, където има много скали, в които обичайно гнезди сокольт скитник (şahin).

Трите споменати дотук соколи са основните породи грабливи птици, които се улавят и отглеждат от българските соколари. Османската документация показва, че ястребите се ловят и отглеждат главно от турци мюсюлмани. Едната порода ястреби, дресирани за ловни нужди, на турски се нарича атмаджа (atmaca) и в науката е известен като мальк ястреб (Accipiter nisus). Друг вид ястреби в османската документация се назовава балабан (balaban, тази турска дума означава «голям, огромен», но също така се използва за назоваване на вид ястреб), като това е породата голям ястреб (Accipiter gentilis).

Цялата соколарска организация в Османската империя е подчинена на началника на дворцовата служба по отглеждане на ловните соколи чакърджъбашията. Наименованието на тази управленска длъжност се състои от две турски думи - çakır (чакър, порода сокол) и baş (глава, главен, началник), като може да се преведе най-общо като главен соколар.

Към дворцовата соколарска служба са създадени три бьолюци (от турската дума bölük - група, подразделение, военна рота) - чакърджии (çakırcı), шахинджии (şahınci), и атмаджаджии (atmacacı).

Първата група са соколарите, които улавят и дресират соколи от породите мальк сокол чучулигар (çakır, латинско наименование Falco columbarius) и ловен сокол (doğan, латинско наименование Falco cherrug).

Втората категория соколари са онези, които улавят и дресират сокол скитник (şahin; falco peregrinus).

Tpemama zруna са лицата, които улавят и дресират ястреби от породите мальк и голям ястреб (atmacac1 и balaban; латински наименования Accipiter nisus и Accipiter gentilis).

Споменатите три групи соколари съществуват и в провинцията, където на място извършват всички дейности по улавянето, отглеждането и дресирането на соколите и ястребите. В отделните региони техни началници са доганджъбашиите (от турските думи «doğan» (сокол) и baş - «глава, главен, началник»). Трите основни породи соколи се улавят и дресират от значителен брой български селяни, които са регистрирани в описите на чакърджиите и шахинджиите в османската провинция Румелия (балканските владения на Османската империя). 
Според османската документация чакърджиите се разделят на две групи според дейността си. По-голям брой соколари-чакърджии, наречени юваджии (от турската дума «уuva», означаваща «гнездо» и наставката за професия «с1») издирват гнездата на соколите във високите дървета и вземат от там малки соколи, които предават за отглеждане на втората група, наречена гюреджии (от «gürenc», означаващо «махане, падане на перата» и наставката за професия с1), които имали задължението да отглеждат соколите и да чистят перата им.

Групата на соколарите шахинджии също е разделена на две групи. Но тъй като сокольт скитник обитава скалисти и планински райони, хората, които търсят гнезда на соколи, се наричат каяджии (от турската дума «kaya», която значи «скала» и наставката с1).

След като уловят малки соколи, каяджиите също ги предават за отглеждане и дресировка на гюреджии. Една съвсем отделна група соколари, която лови всички видове соколи и ястреби, са така наречените тузакчии (от турската дума «tuzak», означаваща «капан» и наставка за професия «с̧ı»). Тези хора поставят специални клетки, капани, в които улавят вече възрастни соколи и ястреби.

Османо-турският език се базира на турската лексикална и граматична основа, но в него се срещат много арабски или персийски думи и граматически конструкции. Наблюденията ни върху османската документация показват, че всички видове соколи и ястреби, както и дейностите по тяхното улавяне, отглеждане и дресировка са назовавани главно с турски и по-рядко с персийски думи.

\section{Архивни източници:}

1. Başbakanlık Osmanlı Arşivi (BOA), TD 317, ff. 1-102: регистьр на соколарите от бьолюка на шахинджиите в Румелия от 1560 г.

2. BOA, TD 325, ff. 1-90: регистър на соколарите от бьолюка на чакърджиите в Румелия от 1560 г.

\section{Лumepamypa:}

1. Арабаджиев, Ив. Хищните птици в България. - София: Държавно издателство «Наука и изкуство». - 1962. - 176 стр.

2. Йорданов, Кр. Организационно устройство на соколарската институция, числен състав и географско разпределение на соколарите от Централните Балкани през XV-XVI в. Исторически преглед, 2016. - № 1-2. - Стр. 227-289.

3. Стојановски, Ал. Раја со специјални задолженија во Македонија (војнуци, соколари, оризари и солари). - Скопје, 1990.

4. Цветкова, Б. Соколарството в Никополски и Видински санджак през XV-XVI в. Годишник на Софийския университет. Исторически факултет, Т. 73, 1979. - Стр. 5-27.

5. A Turkish and English lexicon. Shewing in English the significations of the Turkish terms. By Sir James W. Redhouse. 2 Edition. - Istanbul, 1992.

6. Gibb, H. A. R., Bowen, H. Islamic Society and the West. A Study of the Impact of Western Civilization on Moslem Culture in the Near East. Vol. 1. - London, 1950.

7. Inalc1k, Halil. Doghandji, Encyclopaedia of Islam. - New Edition, Vol. II. - Leiden, 1965. - Pp. 614-615.

8. Kunt, M. The Sultan`s Servants. The Transformation of Ottoman Provincial Government (1550 - 1650). - New York, 1983.

9. Uzunçarşıll, Ismail Hakkı. Osmanlı devletinin saray teşkilati. - Ankara, 1945, - Pp. 420-424.

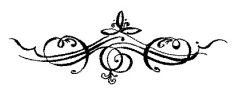


Алёна Іванауна Калечиц (м. Нітра, Словаччина), канд. філол. наук, доцент кафедри русистики Університету ім. Константіна Філософа в Нітрі (Словаччина)

\section{doi: $10.33245 / 20-05-2021-44-46$}

\section{Творчий підхід в навчанні писемного мовлення словацьких студентів, які вивчають російську мову}

Анотація: $У$ тезах представлений пери за все власний досвід роботи з навчання креативного письма словащьких студентів $і$ в цілому творчого підходу в процесі викладання у ЗВО. Розмежовуються поняття творчості і креативності, наводяться конкретні приклади реалізації активних методів роботи і прийомів їхньої реалізації у навчальній практиці.

Ключові слова: творчість, креативність, інновачійні методи, критичне мислення, рефлексивне письмо.

The topic: «A creative approach to teaching Russian language writing to Slovak students»

Abstract: The thesis primarily presents our own experience in teaching creative writing to Slovak students and creativity in general in the process of teaching at the university. The concepts of creative activities and creativity are differentiated and concrete examples of active methods and techniques of their implementation in teaching practice are given. writing.

Key words: creative activities, creativity, innovative methods, critical thinking, reflective

Тема: «Творческий подход в обучении письменной речи словацких студентов, изучающцх русский язык»

Аннотация: В тезисах представлен прежде всего собственный опыт работы по обучению креативного письма словачких студентов и в челом творческого подхода в прочессе преподавания в вузе. Разграничиваются понятия творчества и креативности, приводятся конкретные примеры реализачии активных методов работы и приёмов их реализации в учебной практике.

Ключевые слова: творчество, креативность, инновационные методы, критическое мыиление, рефлексивное письмо.

Проблема творческого подхода в обучении студентов не является новой. Она решается многими учёными-лингвистами, методистами, а также преподавателями-практиками (например, см. работы Голуб - Розенталь, 2018; Купина, 2017; Норман, 2011; Калечиц - Макаровска, 2020; Švec, 2011; Zahatňanská -Kušnírová, 2017; Kosturková - Ferencová, 2019; Petlák, 2020 и др.). Однако в методике преподавания иностранного языка рассмотрению данного вопроса, на наш взгляд, не уделяется должного внимания.

Возможно, это происходит потому, что творчество считается очень сложным мыслительным процессом, основанном на прочных знаниях в той области, в которой происходит создание какого-либо аутентичного продукта. 
Многие учёные творчество сравнивают с креативностью, т. е. считают эти понятия синонимичными, другие же - предлагают их не отождествлять (Gortych D. a kol., 2021, c. 26).

Мы придерживаемся взгляда, что творческий подход в обучении тесным образом связан с развитием критического мышления и базируется на развитии рефлексивного письма, как правила, являющегося результатом вдумчивого чтения (сравн. Kalechyts, 2018, s. 270; Калечиц, 2016, с. 83 и др.). Однако понятие креативности имеет более узкое значение, так как в первую очередь основано на нетрадиционном видении окружающей действительности и входит в дефиницию понятия творчество.

Согласно мнению Й. Маняка, следует различать четыре фазы развития творческих способностей у детей: спонтанное творчество, инновационное, инвентивное и гениальное (Maňák, 1997, s. 67). Причём уже именно на стадии инновационного творчества подразумевается развитие креативности, связанной с созданием собственных нетрадиционных работ.

Таким образом, творческий подход в обучении относится к одной из стратегий инновационного образования вместе с методами развития критического мышления, а также иными активными методами обучения, включая метод «драматического» воспитания, основанный на умениях, необходимых для проведения и участия в ролевых играх и выполнения других заданий, имеющих занимательный характер либо форму проведения (Zahatňanská Kušnírová, 2017; Müglová a kol., 2010).

Как отмечают известные методисты, написание самостоятельных творческих работ студентов является одним из видов деятельности при обучении письменной речи (Крючкова - Мощинская, 2011, с. 403). Уже на начальном этапе обучения они учатся формулировать свои мысли на письме в виде отдельных предложений, на среднем - писать изложения, сочинения и эссе, высказывая своё мнение и обобщая известные факты, «составлять ясные, подробные описания реальных или выдуманных событий» (Там же, с. $421-422)$.

Таким образом, как, впрочем, широко известно, обучение письменной речи иностранных студентов опирается на другие виды деятельности - чтение, аудирование и говорение. Иными словами, согласно нашему опыту, развитие умений составления собственных письменных произведений происходит на основе таких же прочитанных либо услышанных текстов.

По этой причине сам преподаватель должен иметь склонность к работе с занимательным материалом, замечать в обычных вещах необычные моменты, находить и отбирать такие факты из жизни.

Применяя творческий подход в работе со словацкими студентами, на занятиях по изучению русского языка как иностранного даются упражнения на развитие письменной диалогической и монологической речи студентов, формирование умений наблюдать и извлекать из жизни необычные факты и события, интерпретировать их и придумывать новые (см. Калечиц - Макаровска, 2020).

Необходимо отметить, что словацкие студенты считают самыми интересными для выполнения задания на завершение историй анекдотического характера, составление шуточных объявлений и гороскопов, а также упраж- 
нения с использованием в письменной речи фразеологизмов, например, при описании своего внешнего вида или предполагаемого друга.

Кроме того, словацкие студенты с удовольствием выполняют трансформационные упражнения, так называемые перевёртыши, сущность которых заключается в подборе антонимов, а также задания на дополнение или изменение предложенного текста стилистически подходящими словами и словосочетаниями и т.д.

Отличным стимулом к написанию собственных текстов являются конкурсы на лучшее (креативное) объявление, описание, рецепт и т.п., главным критерием оценки которых считается их нешаблонность.

Как результат творческого подхода в обучении могут быть и выпускные студенческие работы, практическая часть которых ориентирована на создание различных оригинальных текстов.

Таким образом, вначале обучения продукт собственного производства может иметь имитационный или дополняющий характер, на среднем - трасформационный и репродуктивный, а на продвинутом этапе - собственно творческий. Результатом такой планомерной работы на любом уровне обучения должен стать текст, созданный студентом самостоятельно.

\section{Список литературы:}

1. Голуб И. Б., Розенталь Д. Э. Занимательная стилистика: Как мы говорим. А как мы пишем!.. - Москва, 2018. - 304 с.

2. Калечиц А., Макаровска О. Креативное письмо. - Ч. 1. Только начинаем. - СанктПетербург, 2020. - 144 с.

3. Калечиц Е.И. Рефлексивное чтение при обучении выразительности речи // Художественный текст в иностранной аудитории: когнитивно-деятельностный подход. Саарбрюккен, 2016. $-184 \mathrm{c}$.

4. Купина Н. А. Креативная стилистика: учеб. пособие. 3-е изд., стер. - Москва, 2017.

5. Крючкова Л.С., Мощинская Н.В. Практическая методика обучения русскому языку как иностранному: учеб. пособие. 2-е изд. - Москва, 2011. - 480 с. $384 \mathrm{c}$.

6. Норман, Б. Ю. Русский язык в задачах и ответах: сборник задач. - Москва, 2011. -

7. Gortych D. a kol. Dysertacie wyaziału Neofilologii UAM w Poznani (nowa seria) 11. Językoznawstwo. Mozaika glottodydaktyczna. Edukatorium w kształtowaniu kreatywności zawodowej glottodydaktyków. - Poznań, 2021. - 384 s.

8. Kalechyts A. Formovanie kritického myslenia na hodinách ruského jazyka na vysokej škole // Inovatívne trendy v odborových didaktikách v kontexte požiadaviek praxe: Zborník štúdií z medzinárodnej vedeckej konferencie. - Nitra, 2018. $240 \mathrm{~s}$.

9. Kosturková M., Ferencová J. Stratégia rozvoja kritického myslenia. - Bratislava, 2019. -

10. Maňák J. Alternativní metody a postupy. - Brno, 1997. - 89 s.

11. Müglová D. a kol. Cudzie jazyky s det'mi - kreatívne a hravo. - Nitra, 2010. - $113 \mathrm{~s}$.

12. Petlák E. Inovácie v edukácii. - Bratislava, 2020. - $196 \mathrm{~s}$.

13. Zahatňanská M., Kušnírová E. Metódy podporujúce aktívne vyučovanie. - Prešov, 2017. $-178 \mathrm{~s}$.

14. Švec Š. Inovatívne prístupy v didaktike. - Bratislava, 2011. - $188 \mathrm{~s}$.

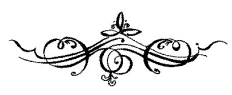


Юлія Григорівна Косенко (м. Суми, Україна), викладач кафедри іноземних мов Сумського національного аграрного університету

doi: $10.33245 / 20-05-2021-47-49$

\section{Комунікативні ситуації у процесі навчання української мови як іноземної}

Анотація: Подано зразки комунікативних ситуацій у процесі навчання украӥнської мови як іноземної, розкрито їх зміст.

Ключові слова: комунікативна ситуаџія, комунікативне читання, українська мова як іноземна.

The topic: «Communicative situations in the process of learning Ukrainian as a foreign language»

Abstract: The samples of communicative situations in the process of learning Ukrainian as a foreign language are given, their content is described. language.

Key words: communicative situation, communicative reading, Ukrainian as a foreign

Комунікативна ситуація у процесі навчання професійно зорієнтованого діалогічного мовлення іноземних студентів - це така ситуація, в якій умови й обставини підпорядковані єдиній меті: розв'язати завдяки спілкуванню певну професійну проблему реального життя, прийняти рішення, досягти бажаного результату. Такі ситуації передбачають свідоме використання студентами засвоєного фахового матеріалу на практиці [1, С. 75].

Т. Кудіна наголошує, що умовою реалізації говоріння $\epsilon$ наявність мовленнєвих автоматизмів або мовленнєвих навичок (Л. Виготський, А. Лурія, М. Жинкін, О. Леонтьєв, Т. Рябова, С. Сільвестрова). У процесі навчання мовам важливими є ситуації дійсності, що спонукають до говоріння. Такі ситуації називають комунікативними. Умовно-комунікативні і комунікативні вправи складають обов'язковий компонент контенту навчального курсу для іноземних слухачів [2, С. 8].

Комунікативне читання - одна 3 головних цілей навчання будь-якої іноземної мови з орієнтацією на практичне застосування. В основу комунікативного читання покладене конкретне комунікативне завдання і настанова на ступінь повноти та точності отримання інформації. Це читання з вибірковим вилученням інформації, читання з розумінням основного змісту, читання 3 повним розумінням тексту [2, С. 8$]$.

Т. Кудіна стверджує, що в процесі комунікації письму надається менше уваги, ніж говорінню, аудіюванню та читанню, але у навчальному процесі воно 
використовується як ефективний засіб розуміння, закріплення, заучування та використання лексичних і граматичних явищ [2, С. 9].

Пропонуємо розглянути зразки комунікативних ситуацій для студентівіноземців у процесі навчання української мови як іноземної. Запропонована робота має на меті допомогти інокомунікантам у вирішенні завдань комунікативного підходу у процесі вивчення нерідної мови. 3 практичним використанням комунікативних ситуацій можна ознайомитися іноземним студентам на YouTube каналі «Твій успіх» за покликанням: https://www. youtube. com/channel/UCLHrL4yHWDwHLPW phFHL1BQ.

1. Ви розмовлясте з другом, який щцйно орендував квартиру, а зараз вважає, що помилився у виборі саме цієї квартири.

Заперечте другу та переконайте його у тому, що він зробив правильний вибір. В аргументах Ви повинні використовувати різні мовні засоби заперечення.

2. Ви телефонуєте своєму сімейному лікарю.

Повідомте йому, що Вам потрібна консультація, оскільки у Вас підвищена температура та сильно болить горло.

\section{3. Припустіть, що Ви захворіли.}

Напишіть про Вашу хворобу. (9-10 речень). Використовуючи наступні слова та словосполучення: хворіти, захворіти, у мене болить, живіт, голова, горло, скаржитися, відчувати, температура, нежить, лікувати, лікуватися, лікар, радити, здоров'я.

\section{4. Попросіть бібліотекара видати Вам книги з біології.}

\section{5. Напишіть, як і де Ви живете у місті Суми.}

6. Напишіть лист другу про Ваше рідне місто.

Як називається Ваше місто? Де розташоване? Які головні вулиця та площа в ньому? Скільки мешкає людей? Чим славиться Ваше місто? Які є цікаві в ньому місця? Куди Ви любите ходити?

7. Напишіть, будь ласка, про щцо Ви розмовлясте вдома за сніданком або вечерею.

\section{8. Напишіть, як пройщов Ваш звичайний день.}

Що Ви робили, скільки часу це зайняло, з якими людьми зустрічалися та розмовляли? Де Ви сьогодні були? Розкажіть про це.

9. Напишіть, на які теми Ви розмовлясте з друзями.

Чи розповідають вони Вам про своє життя? Розкажіть про це. 


\title{
10. Ви любите дарувати подарунки?
}

Напишіть, що Ви звичайно даруєте другу, подрузі, мамі, тату, брату, сестрі. Чому Ви даруєте їм саме ці подарунки? Що дарують Вам Ваші друзі та рідні?

\section{1. Про щцо Ви мрієте?}

Напишіть про Ваші мрії. Розкажіть про це.

\section{2. Вам подобається гуляти у парку? Ви гуляєте один чи з друзями?}

Напишіть про те, як Ви ходили на екскурсію разом з друзями. Що Ви бачили? Розкажіть про це.

\author{
13. Напишіть про Вашого друга (подругу) за планом: \\ 1. Статура (фігура). \\ 2. Зріст. \\ 3. Обличчя (губи, лоб, ніс, очі, вії, брови). \\ 4. Волосся (колір, довжина), зачіска. \\ 5. Одяг, взуття. \\ 6. Характер.
}

Розкажіть, коли Ви познайомились, чому Ви дружите з цією людиною.

Використовуйте слова: стрункий, повний, нормальної статури, високий, невисокий, тонкий, повний, прямий, довгий, короткий; темний, світлий; прямий, хвилястий; блондин, блондинка, брюнет, брюнетка; стрижка, хвіст, чубчик, добрий, злий, працьовитий, лінивий, любий тощо.

\section{4. Робота в групах.}

В автобус увійшов втомлений дідусь. Усі місця зайняті. Водій звернувся до студента: «Поступися місцем дідусеві. Подивися, який він втомлений. - «А я не втомився? I звідки я знаю, можливо, цей дідусь не гідний того, щоб йому поступалися місцем».

Чи правильно повів себе студент? Щоб Ви зробили в цій ситуації?

Отже, комунікативні ситуації у процесі у процесі навчання української мови як іноземної сприяють розвитку комунікативних умінь і навичок учнів у процесі вивчення української мови як іноземної.

\section{Список літератури:}

1. Іванишин Г. Я. Навчання професійно зорієнтованого діалогічного мовлення іноземних студентів медичних спеціальностей у процесі вивчення української мови: дис... канд. пед. н.: 13.00.02 / Херсонський державний університет. - Херсон - Івано-Франківськ, 2013. - $252 \mathrm{c}$.

2. Кудіна Т. М. Формування лексичної компетентності української мови і іноземних слухачів підготовчих відділень: автореф. дис. ... канд. пед. наук: 13.00.02 / Нац. пед. університет імені М. П. Драгоманова. - Київ, 2013. - 23 с.

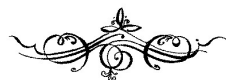


Лариса Михайлівна Кужелсва (м. Запоріжжя, Україна), викладач Центру підготовки іноземних громадян, Запорізького державного медичного університету;

Катерина Іллівна Старостенко (м. Запоріжжя, Україна), викладач Центру підготовки іноземних громадян, Запорізького державного медичного університету;

\section{doi: $10.33245 / 20-05-2021-50-52$}

\section{Організація самостійної роботи з української мови іноземних слухачів довузівського етапу підготовки}

Анотація: У тезах автори вказують на важливість самостійної роботи у процесі навчання іноземних слухачів довузівського етапу підготовки. Також описують різні форми самостійної роботи студентів (СРС) з украӥнської мови, особливості ї ефективної організачіï.

Ключові слова: викладання української мови, аудиторна $i$ позааудиторна СРС, організація самостійної роботи іноземних слухачів.

The topic: «Organization of independent work on the Ukrainian language of foreign students of pre-university stage of preparation»

Abstract: In these thesis the authors point to the importance of independent work in the learning process of foreign students of pre-university stage of preparation. They also describe various forms of student's independent work (SIW) on the Ukrainian language, features of its effective organization.

Key words: teaching the Ukrainian language, extra-classroom SIW, organization of independent work of foreign students.

Навчання іноземних студентів у медичних закладах України значно сприяє інтеграції вітчизняної медичної школи у світовий інтелектуальний простір та стимулює розвиток освіти і науки. В умовах реформування освітньої системи в Україні значне місце займає пошук ефективних методів і засобів навчання, розробка методичних систем, технологій викладання, підвищення дієвості навчання в цілому.

У зв 'язку з цим у навчальних планах вузів збільшено кількість годин на самостійну роботу студентів (СРС). Особливе значення набуває викладання української мови, якою і відбувається навчання. Знання української мови $\epsilon$ неодмінною умовою отримання фахових знань, а також необхідним засобом повноцінного спілкування для іноземних студентів.

Як відомо, процес вивчення будь-якої мови, зокрема української мови як іноземної, неможливий без самостійної роботи тих, хто навчається. Питання самостійної роботи студентів у вищих навчальних закладах неодноразово висвітлювалося у працях відомих педагогів: Р. Гуревича, Н. Герман, 
Н. Тягунової, В. Буряка,В. Лихача, Л. Васецької та інших. Під самостійною роботою ми розуміємо навчальну діяльність студента 3 виконання завдань викладача або за власним бажанням, яка спрямована на закріплення, розширення та поглиблення раніше отриманих знань, а також на засвоєння нового матеріалу.

Самостійна робота $є$ важливим компонентом в організації навчального процесу. Форми і методи цієї роботи зумовлюються кількома чинниками, найважливішим з яких $є$ мотивація навчання та загальний рівень тих, хто навчається. Отже, роль самостійної роботи 3 української мови слухачівіноземців довузівського етапу підготовки в навчальному процесі зростає, особливо у сучасних реаліях дистанційного навчання.

У процесі викладання української мови необхідно створити такі умови, які б дозволяли іноземному слухачеві переконатися в значущості української мови для індивідуального становлення майбутнього спеціаліста, закріпити в нього бажання і здатність читати, самостійно переосмислювати чужі думки й на цій основі формулювати, висловлювати свої. Певний обсяг знань, навичок, умінь, здатність аналізувати, осмислювати факти формується насамперед у процесі самостійної роботи, яка розглядається як рівноправна форма навчальних занять.

Розрізняють різні організаційні форми СРС: робота слухача-іноземця, яка виконується самостійно у вільний від занять час, поза аудиторією; індивідуальна робота слухача - це аудиторна самостійна робота за індивідуальними завданнями під керівництвом викладача, під час якої студент може отримати допомогу у вигляді консультації.

Під час виконання самостійної роботи набуті іноземними слухачами знання будуть розширюватися і поглиблюватися. До того ж вироблятимуться навички науково-дослідної роботи, необхідні сучасному фахівцю в будь-якій сфері діяльності.

Самостійна робота слухачів-іноземців довузівського етапу підготовки під час аудиторних занять, їхня активність, застосування ефективних методів $\mathrm{i}$ прийомів викладання української мови як іноземної запобігають перевантаженню домашніми завданнями, роблять оптимальними їхній обсяг і характер.

Технологія і організація СРС повинна бути поетапною і обгрунтованою. Для цього необхідна готовність професорсько-викладацького складу, якісна навчально-методична та відповідна нормативно-правова база. Отже, органічне поєднання аудиторного заняття 3 домашньою самостійною роботою забезпечить формування необхідного рівня володіння українською мовою іноземними слухачами згідно вимог довузівського етапу підготовки.

Організація самостійної роботи 3 української мови на цьому етапі повинна бути спланована таким чином, щоб забезпечити як успішне оволодіння учбовим матеріалом, так і розвиток творчої учбово-пізнавальної активності тих, хто навчається, оскільки сформувати мовний механізм можливо тільки при умові активної самостійної діяльності самих слухачів.

Ефективність самостійної роботи у процесі навчання залежить від умов іï організації, від змісту й характеру знань, логіки їхнього викладу, джерела 
знань, від якості досягнутих слухачами-іноземцями результатів у ході виконання цієї роботи. Навички і вміння самостійної роботи формуються не самі по собі, а в результаті спеціально організованих вправ, що органічно включаються в навчальний процес. Різноманітність видів СРС оживляє процес навчання, викликає інтерес до вивчення української мови, спонукає вдосконалювати знання, навички та вміння тих, хто навчається.

До різних видів самостійної роботи можна віднести проведення консультацій, індивідуальних занять та перевірка виконання слухачами завдань, наданих для самостійного опрацювання. Індивідуальна робота 3 текстами, тренування $з$ перекладу їх українською мовою, робота зі словниками також сприяють формуванню знань, вмінь та навичок мовної підготовки майбутніх фахівців.

Організацію СРС необхідно здійснювати, враховуючи взаємозв'язок різних видів самостійної роботи слухачів як в аудиторії, так і в позааудиторній самостійній роботі, урізноманітнювати їх. Мета позааудиторної роботи - міцне закріплення вивченого на уроці матеріалу, більш глибоке його осмислення, подальший розвиток навичок і умінь самостійної роботи.

Позааудиторна робота повинна носити творчий характер. Дуже важливо навчити слухачів підготовчого відділення складати план прочитаного, працювати 3 підручником, вміти формулювати висновок по темі в цілому. Не менш важливо допомогти іноземним слухачам самостійно набувати не обхідну інформацію з альтернативних джерел.

Завдання з самостійної роботи повинні бути різного рівню складності, їхній діапазон повинен поширюватися від найпростіших до більш складних, головною метою яких повинно стати не тільки закріплення знань, отриманих на заняттях, але й перетворення їх в уміння та навики - завдання першого рівня.

Завдання більш високого рівня повинні включати в себе формування й розвиток складніших вмінь - сприйняття і відображення отриманої інформації 3 елементами власного коментування з різними видами опор. Важливо, щоб такі завдання були посильними, цікавими i носили рецептивно-репродуктивний характер.

Отже, ми вважаємо, що головною метою організації самостійної роботи 3 української мови іноземних слухачів довузівського підготовки є активізація творчої, пізнавальної діяльності та вдосконалення і практичне використання набутих знань.

\section{Список літератури:}

1. Буряк В. К. Самостоятельная работа учащихся / В. К. Буряк. - М.: Просвещение, 1984. -164 c.

2. Герман А. Адаптація форм організації самостійної роботи студентів до сучасних технологій навчання / А. Герман, Н. Тягунова // Вища школа. - 2001. - № 4-5. - С. 53-61.

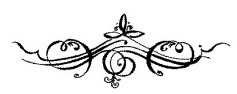


Віталій Володимирович Макарчук (м. Біла Церква, Україна), канд. юридичних наук, асистент кафедри конституиійного права та теоретико-правових дисииплін Білочерківського національного аграрного університету

\section{doi: 10.33245/20-05-2021-53-55}

\section{Українська мова як чинник національної безпеки (правові аспекти)}

Анотація: $Y$ тезах автор описуе правові аспекти стану української мови, як основного чиннику начіональної безпеки. Наведено визначення та ін.ші чинники національної безпеки. Розглянуто та проаналізовано Стратегію Кабінету Міністрів України щзодо популяризаиії української мови до 2030 року «Сильна мова - успішна держава».

Описано дієвість правових механізмів утвердження української мови як державної. Доведено, щзо функиії державної мови, як правило, виконує рідна мова більшості населення краӥн світу та наведено винятки з иьього правила. Вказані перспективи внесення украӥнської мови до державних символів.

Ключові слова: нащіональна безпека, украӥнська мова, правовий статус, конституційний лад.

The topic: "Ukrainian language as a factor of national security (legal aspects) "

Abstract: In the thesis, the author describes the legal aspects of the state of the Ukrainian language as a major factor in national security. Definitions and other factors of national security are given. The Strategy of the Cabinet of Ministers of Ukraine on popularization of the Ukrainian language until 2030 «Strong language - a successful state» is considered and analyzed.

The effectiveness of legal mechanisms for establishing the Ukrainian language as the state language is described. It is proved that the functions of the state language, as a rule, are performed by the native language of the majority of the population of the world and exceptions to this rule are given. Prospects for the introduction of the Ukrainian language in state symbols are indicated.

Key words: national security, Ukrainian language, legal status, constitutional order.

Із стародавніх часів мова як чинник державності та національної безпеки відігравала провідну роль. Її політичний аспект найточніше визначили древні римляни: «Чия мова - того й влада», маючи на увазі латинську мову Римської імперії. Доволі складна ситуація з державною мовою як складовою частиною конституційного ладу є ознакою наявності перманентної недооціненої загрози національній безпеці України.

Національна безпека - це стан захищеності життєво важливих інтересів особи, суспільства та держави від внутрішніх і зовнішніх загроз [1, с. 36].

До чинників національної безпеки належать: інформаційний (захист українського інформаційного простору - телебачення, радіо, інтернет - від стороннього впливу); освітній (захист українського освітнього простору від стороннього впливу), науковий (підтримка й розвиток національних наукових структур), культурний (забезпечення розвитку національної культури), 
релігійний (забезпечення безперешкодного функціонування української церкви) та мовний, що передбачає забезпечення безперешкодного функціонування української державної мови в усіх сферах суспільного життя.

Мовний же чинник в означеному комплексі можна вважати основним, оскільки він репрезентований у кожному 3 названих факторів: медіа-засоби функціонують у вербальній реалізації, освіта та наука зобов'язані функціонувати державною мовою, i розвиток такої ж наукової метамови на часі. Культурний же чинник безпосередньо пов'язаний з українською мовою, що у сферах фольклору, музики та літератури відіграє визначальну роль [2].

Розпорядженням Кабінету Міністрів України від 17 липня 2019 р. схвалена Стратегія популяризації української мови до 2030 року «Сильна мова - успішна держава». Всебічний розвиток української мови як однієї 3 найважливіших складових національної ідентичності українського народу $\epsilon$ гарантією національної безпеки і суверенітету України та забезпечує єднання нації. Ця Стратегія визначає мету, стратегічні цілі та основні завдання, на виконання яких має бути спрямована реалізація державної мовної політики, та охоплює всі сфери суспільного життя.

Розроблення Стратегії зумовлено необхідністю кардинальних змін, спрямованих на підвищення популярності та конкурентоспроможності української мови в Україні та світі.

Стрімкі процеси глобалізації та інтенсивного технологічного розвитку призвели до появи широкого спектра нових викликів і загроз, перед якими нині постала i Україна, зокрема у сфері національної безпеки, економічній, інформаційній, гуманітарній сферах [3].

«Питання державної мови - це питання національної безпеки, ... українська мова - це основа конституційного ладу. Тому кожна спроба підірвати мовне законодавство - це спроба удару по національній безпеці і по національній обороні» як наголошує уповноважений із захисту державної мови Т. Д. Кремінь [4] - посадова особа в Україні, правовий статус якої визначений розділом 8 Закону України «Про забезпечення функціонування української мови як державної» [5].

Із початком процесу утворення національних держав феномен мови як основного маркера нації ще в XVII ст. вийшов за межі лінгвістичної та культурної царини й набув уже не лише націєтворчої, але й державотворчої функції. Якщо в етносу немає своєї мови, часто він не має достатніх підстав називатися окремим народом, а тим паче нацією, та відповідно недостатньо підстав для претензій на самостійну державу. Д. Мейс американський i український історик, політолог, журналіст, громадський діяч застерігав нас: «Це сувора діалектика - щоб піти далі, треба знати, звідки йти. Щоб стати європейцем, треба стати українцем. Щоб стати громадянином світу, треба стати українцем і європейцем. І цей шлях самоідентифікації треба пройти. I починати сьогодні і тепер, бо завтра буде пізно» [6].

Хоча функції державної мови часто виконує рідна мова більшості населення країн світу. Винятком 3 цього правила $\epsilon$, наприклад, Канада, Сполучені Штати Америки, Швейцарія, але це історично пояснюється відсутністю в них власних мов. 
Згідно з ст. 20 Конституції України: «Державними символами України є Державний Прапор України, Державний Герб України, Державний Гімн України». Слід зазначити, що Державна Мова України як основний державотворчий чинник не потрапила до державних символів, хоча вона має право посідати ключове місце серед Державних символів України. Українська мова без сумніву відіграє основну консолідуючу роль у державі та $\epsilon$ чинником національної безпеки України.

Отже, наявність дієвих правових механізмів утвердження української мови як державної прискорює реалізацію української національної державності, підвищує рівень соціального партнерства та національної консолідації українського суспільства.

\section{Список літератури:}

1. Шемшученко Ю.С. Юридична енциклопедія : в 6 т. - Київ : «Українська енциклопедія», 1999. - Т. 1: А - Г. -672 с.

2. Демченко В.М. Українська мова як чинник державної безпеки України. Теорія та практика державного управління $i$ місцевого самоврядування. URL: http://nbuv.gov.ua/UJRN/Ttpdu_2016_2_6

3. Про схвалення Стратегії популяризації української мови до 2030 року «Сильна мова - успішна держава»: Розпорядження Кабінету Міністрів України від 17.07.2019 p. № 596-р. URL: https://zakon.rada.gov.ua/ laws/show/596-2019-\%D1\%80\#Text

4. Кремінь Т.Д. Уповноважений із захисту державної мови: Найближчими роками жодних змін у мовний закон вносити не можна. URL: https://mova-ombudsman.gov.ua/news/taraskremin-najblizhchimi-rokami-zhodnih-zmin-u-movnij-zakon-vnositi-ne-mozhna

5. Про забезпечення функціонування української мови як державної: Закон України від 25.04.2019 р. № 2704-VIII. - URL: https://zakon.rada.gov.ua/ laws/show/2704-19\#Text

6. Лямцев К. Українська мова як чинник національної безпеки української держави: Слово Просвіти. - URL: http://slovoprosvity.org/2018/09/27/ ukrajinska-mova-yak-chynnyknatsionalnoji-bezpeky-ukrajinskoji-derzhavy/

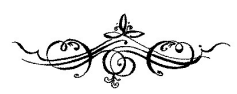

УДК 342.95

Олександр Іванович Нікітенко (м. Біла Церква, Україна), доктор юридичних наук, професор кафедри сочіально-гуманітарних дисииплін факультету права та лінгвістики Білочерківського начіонального аграрного університету

\section{doi: $10.33245 / 20-05-2021-55-57$}

\section{Правове регулювання у сфері застосування української мови (адміністративний аспект)}

Анотація: У тезах автор описує адміністративний аспект правового регулювання у сфері застосування украӥнської мови. Наголошується, що надзвичайно важливе місие посідає реформа правової системи та реформа адміністративного права в Україні.

Ключові слова: украӥнська мова, Конституція України, українське законодавство, адміністративна реформа. 
The topic: "Legal regulation in the field of application of the Ukrainian language (administrative aspect) "

Abstract: In the theses the author describes the administrative aspect of legal regulation in the field of application of the Ukrainian language. It is emphasized that the reform of the legal system and the reform of administrative law in Ukraine occupy an extremely important place.

Key words: Ukrainian language, Constitution of Ukraine, Ukrainian legislation, administrative reform.

У процесах реформування українського суспільства надзвичайно важливе місце посідає реформа правової системи України. Потреба в ії проведенні та прискоренні стала вкрай актуальною після вступу України до Ради Свропи (листопад 1995 р.), з яким було пов'язане державою роду зобов'язань, в тому числі всебічного розвитку і функціонування української мови в усіх сферах суспільного життя України.

Ст. 10 Конституції України визначає: «Державною мовою в Україні $є$ українська мова. Держава забезпечує всебічний розвиток і функціонування української мови в усіх сферах суспільного життя на всій території України. В Україні гарантується вільний розвиток, використання і захист російської, інших мов національних меншин України. Держава сприяє вивченню мов міжнародного спілкування. Застосування мов в Україні гарантується Конституцією України та визначається законом» [1].

Головною метою реформи правової системи є досягнення най повнішого забезпечення адміністративно-правового регулювання конституційних засад організації державної влади, принципу верховенства права, гуманістичних вимог щодо діяльності держави [2].

Складовою частиною всебічного розвитку і функціонування української мови в державі є реформа адміністративного права, яка має на меті: принципові науково-методичні засади в галузі українського адміністративного права у сфері адміністративно-правового регулювання та використання української мови, як державної мови в Україні.

Українська мова протягом багатьох віків не мала повного визначеного статусу. 3 розвитком у багатонаціональних державах, переважно починаючи 3 XIX ст., мовного законодавства вона набула деякого офіційного значення на території Галичини, Буковини та Закарпаття, що входили до складу АвстроУгорської імперії.

Хочу підкреслити, що пріоритет надавався відповідно польській, німецькій та угорській мовам. У зв’язку з цим в українській політичній думці минулого відстоювалася «мовна автономія, недоторканість мови в приватному та публічному житті» (Н. П. Драгоманов), а в найбільш радикальних проектах пропонувалося закріпити, що «офіційна мова є українська, але всі мови уживані на Вкраїні, суть вільні» (М.I. Міхновський) [3, с. 5]. 
Основним об'єктом адміністративно-правового регулювання і захисту ст. 3 Конституції України визначається: «Людина, іiі життя і здоров'я, честь i гідність, недоторканність і безпека визнаються в Україні найвищою соціальною цінністю. Права i свободи людини та їх гарантії визначають зміст i спрямованість діяльності держави.

Держава відповідає перед людиною за свою діяльність. Утвердження і забезпечення прав і свобод людини є головним обов'язком держави» та ч. 1 ст. 17, що говорить: «Захист суверенітету і територіальної цілісності України, забезпечення іiі економічної та інформаційної безпеки $\epsilon$ найважливішими функціями держави, справою всього Українського народу» [1], тому держава повинна служити своєму народові.

Конституція України передбачає, що застосування мов в Україні визначається українським законодавством. Нині цю функцію виконує Закон України «Про засади державної мовної політики» від 3 липня 2012 р. який у ст. 2 підкреслює: «Державна мовна політика в Україні має своїм завданням регулювання суспільних відносин у сфері всебічного розвитку і вживання української як державної, регіональних мов або мов меншин та інших мов, якими користується населення країни в державному, економічному, політичному і громадському житті, міжособовому та міжнародному спілкуванні, охорону конституційних прав громадян у цій сфері, виховання шанобливого ставлення до національної гідності людини, іiі мови і культури, зміцнення єдності українського суспільства» [4].

Конституція та Закони України мають важливе значення для упорядкування адміністративно-правового регулювання у сфері застосування української мови та встановлюється виключно Законами України. У законодавстві України передбачена обов'язкова вимога володіння українською мовою в обсязі достатньому для спілкування особами, які набувають громадянство України [5].

\section{Список літератури:}

1. Конституція України: Закон України від 28.06.1996 p. - № 254к/96-BP. - URL: https://zakon.rada.gov.ua/laws/show/254\%D0\%BA/96-\%D0\%B2\%D1\% 80\#Text

2. Про заходи щодо впровадження Концепції адміністративної реформи в Україні: Уаз Президента України від 22.07.1998 p. № 810/98. URL: https:// zakon.rada.gov.ua/laws/show/810/98\#Text

3. Авер'янов В.Б. Коментар до Конституції України. - Київ: Інститут законодавства Верховної Ради України, 1998. - 410 с.

4. Про засади державно мовної політики : Закон України від 03.07.2012 р. - № 5029VI. - URL: https://zakon.rada.gov.ua/laws/show/5029-17\#Text

5. Про громадянство України : Закон України від 08.01.2001 p. - № 2235-III. URL: https://zakon.rada.gov.ua/laws/show/2235-14\#Text

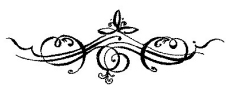


Ольга Валеріївна Нітенко (м. Київ, Україна), доктор педагогічних наук, професор кафедри іноземних мов Воєнно-дипломатичної академії імені Свгенія Березняка

doi: 10.33245/20-05-2021-58-60

\title{
Особливості навчання австрійських студентів в умовах пандемії COVID -19
}

\begin{abstract}
Анотація: У тезах висвітлено основні особливості навчання австрійських студентів в умовах пандемії COVID-19.

Описано протиепідеміологічні заходи, які проводяться університетами; наголошено на збільшенні штату психологічної служби, розміщенні відповідних порад на сайтах закладів вищої освіти. Подано перелік останніх тенденщій у фінансуванні австрійських студентів в умовах корона-кризи. Вказано на зростання популярності закладів вищої освіти, щчо надають освіту повністю в дистаниійному форматі.
\end{abstract}

Ключові слова: австрійські студенти, австрійські університети, пандемія COVID-19, корона криза

The topic: «Peculiarities of Austrian students' education in the conditions of the COVID19 pandemic"

Abstract: The abstract highlights the main peculiarities of the study of Austrian students in the conditions of the COVID-19 pandemic.

The anti-epidemiological measures carried out by universities are described; emphasis on increasing the staff of the psychological service, posting relevant advice on the websites of higher education institutions. A list of recent trends in the financing of Austrian students in the context of the corona crisis is presented. The growing popularity of higher education institutions that provide education entirely in the distance format is indicated. crisis.

Key words: Austrian students, Austrian universities, pandemic COVID-19, Coronavirus

Під час кількох попередніх семестрів в Австрії, як і в багатьох інших європейських країнах, через пандемію коронавірусу заняття в університетах проводилися дистанційно, у форматі онлайн. Однак, 38 лютого 2021 року ситуація дещо змінилася.

Перш за все, університети та інститути зобов'язані визначати власні стратегії тестування й регулярно тестувати як студентів, так і свій академічний персонал. У цьому контексті їм рекомендовано використовувати тестові інфраструктури у відповідних регіонах, але наразі обговорюється також можливість здійснення студентами самостійного тестування на COVID-19 (коли вони беруть мазок самі в себе на вході в університет).

Літній семестр 2021 року університети та інститути Австрії в основному розпочнуть знову в дистанційному режимі. Очні курси та іспити, як правило, будуть можливі лише за умови суворих заходів 3 охорони здоров'я, однак 
проведення лекцій, на яких може бути присутньою значна кількість студентів, не планується.

Щоб запобігти скупченню здобувачів вищої освіти, в очному форматі передбачається проведення лише тих заліків та іспитів, які неможливо замінити контрольними онлайн-заходами. Також університети й інститути $\epsilon$ відповідальними за розширення можливих стратегій тестування. Бібліотеки, читальні зали й навчальні зони можуть працювати 3 відчиненими дверима, наскільки це дозволяє епідеміологічна ситуація.

Кожен заклад вищої освіти самостійно визначає відповідні умови навчання та протиепідеміологічні заходи. Однак, найчастіше такими є маркування місць для студентів в аудиторіях (кольоровим скетчем, фарбою, крейдою тощо), дезінфекція поверхонь у навчальних приміщеннях (столи, парти, стільці, поруччя сходів), наявність антисептиків у всіх приміщеннях закладу.

Оскільки потреба в психологічному консультуванні здобувачів освіти зросла в поточному році на 25 відсотків, кількість штатних працівників психологічних консультацій для студентів у Лінці, Граці, Інсбруку, Зальцбурзі, Клагенфурті та Відні з Великодня 2021 року була збільшена на 40 \%.

На сайтах більшості університетів розміщено поради психологів щодо запобігання депресивним станам та суїцидальним настроям як у здобувачів вищої освіти, так і в академічного персоналу. Також вказано контактні телефони та електронні адреси, за якими можна звернутися до психолога в разі потреби.

Федеральне міністерство освіти, науки та досліджень Австрії оголосило літній семестр 2020 року «нейтральним семестром» щодо фінансування студентів. Слід відмітити наступні важливі особливості фінансування австрійських студентів, які з'явилися протягом літнього семестру 2020 року й діють наразі: матеріальна допомога продовжувала виплачуватися; дію права на отримання матеріальної допомоги за потреби було подовжено на один семестр; у виняткових випадках для отримання стипендії не потрібно було доводити успіхи в своєму навчанні.

Під час пандемії COVID-19 студенти, які працюють, мають можливість подальшого навчання в рамках так званих «навчальних відпусток». У період таких відпусток надається час для роботи, а отриманий вільний час використовується для навчання. Зокрема, в такій ситуації роботодавець виграє від того, що Державна служба зайнятості виплачує студенту додаткову допомогу на навчання протягом усього терміну відпустки для навчання, і роботодавець не виплачує йому заробітну плату.

Крім того, особливо популярними стали ті навчальні заклади, які пропонують навчання повністю онлайн. Так, наприклад, німецький Міжнародний інститут (нім. IU Internationale Hochschule) з екзаменаційними центрами в Відні, Граці та Лінці, який пропонує 105 освітніх програм на бакалавраті й 47 програм у магістратурі, усі процедури - від зарахування до захисту диплому й випускних іспитів - проводить дистанційно [].

У той час, як класичні австрійські університети лише останнім часом працюють над розширенням діапазону цифрових курсів, заклади, які раніше 
почали здійснювати навчання дистанційно або заочно, вже мають хороші позиції в цьому питанні.

Дистанційне навчання стає все більш привабливим для студентів у зв'язку з пандемією коронавірусу. Так, заклади, які здійснюють онлайннавчання, серед іншого, наводять такі його переваги, як: незалежність від коронакризи; перевірена концепція дистанційного навчання; гнучкість щодо часу й місця та цифровий обмін з іншими студентами всередині країни та за кордоном.

Наразі в Австрії існує навіть спеціальний портал, який називається «Заочне навчання» (нім. Fernstudium.at), де потенційні здобувачі освіти можуть знайти необхідну інформацію, що стосується освітньої програми, яка їх цікавить, на будь-якому рівні вищої освіти - на бакалавраті, у магістратурі чи аспірантурі. Перелік освітніх програм викладено в зручному форматі за алфавітом та з вказівкою про їх кількість у закладах вищої освіти.

Даний портал оснащений зручною пошуковою системою; усі посилання активні; інформація, що міститься за ними, актуальна. У базі даних наявні понад 1000 освітніх програм. Для бажаючих існує можливість активації функції оповіщення у випадку появи нових програм; тобто, отримувати нові відомості щодо них можна електронною поштою.

Характерно, що значна кількість австрійських студентів навчається дистанційно в університетах інших німецькомовних країн - Німеччини, Швейцарії, Ліхтенштейну та Люксембурга. У свою чергу студенти перелічених країн навчаються в австрійських університетах.

Звертає на себе увагу, що на сайтах багатьох австрійських університетів як окрема рубрика з'явилися поради здобувачам освіти для ефективного дистанційного навчання. Для того, щоб мати можливість ефективно вчитися у власній квартирі або будинку, фахівці радять дотримуватися певних правил: перед заняттями перевдягатися 3 піжами в повсякденний одяг, облаштувати зручне робоче місце, відкласти смартфон, планувати свій робочий день i тиждень, ставити цілі, у разі виникнення труднощів шукати віртуальний діалог iз одногрупниками й викладачами, а також скласти власний режим дня та дотримуватися його.

Таким чином, досвід подолання австрійськими університетами коронакризи може стати в нагоді українським закладам вищої освіти.

\section{Список літератури:}

1. Fernstudium. - [Електронний ресурс] - Режим доступу: https://www. fernstudium.at/

2. IU Fernstudium. - [Електронний ресурс] - Режим доступу: https://www. studieren.at/hochschulen/iu-fernstudium/ .

3. Mein Studium in Zeiten von Corona. - [Електронний ресурс] - Режим доступу: https://www.studieren.at/studium-corona

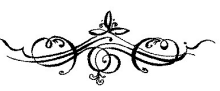


Вікторія Валеріївна Новікова (м. Біла Церква, Україна), канд. економічних наук, доцент кафедри інформаційних систем і технологій, інституиійний координатор програми Еразмус + Білочерківського національного аграрного університету

\title{
doi: 10.33245/20-05-2021-61-65
}

\section{Академічна мобільність як фактор інтеграції України в європейський науково-освітній простір}

\begin{abstract}
Анотація: У статті йдеться про стан розвитку академічної мобільності в Україні на основі аналітичних даних та виокремлення міжнародних освітніх програм, які забезпечують академічну мобільність у європейському освітньому просторі.

Ключові слова: міжнародна академічна мобільність; міжнародний освітній простір; міжнародні освітні програми.

The topic: «Academic mobility as a factor of Ukraine's integration into the European scientific and educational space»
\end{abstract}

Abstract: The article deals with the state of development of academic mobility in Ukraine on the basis of analytical data and the selection of international educational programs that provide academic mobility in the European educational space.

Key words: international academic mobility; international educational space; international educational programs.

У сучасних умовах модернізації та глобалізації освіти, коли освіта і знання стають транснаціональним явищем, особливого значення набуває активна міжнародна співпраця у сфері освіти та науки нашої держави з іншими країнами, що дозволяє створити єдиний європейський освітній простір - зону «Свропейської вищої освіти», особливо актуально в умовах всесвітньої пандемії коронавірусної хвороби 2019-2021 рр. [2].

Формування єдиного світового освітнього простору відбувається через зближення підходів різних країн до організації освіти, а також через визнання документів про освіту інших країн. Загальноєвропейський простір вищої освіти (EHEA) й загальноєвропейський дослідницький простір (ERA) утворюють сучасне європейське суспільство знань.

Спільний європейський освітній простір, з одного боку, сприяє зростанню мобільності студентів та професорсько-викладацького складу, а 3 ін.шого академічна мобільність є необхідною умовою формування самого спільного освітнього простору [3].

Дванадцятого серпня 2015 року Кабінет Міністрів України затвердив постанову № 579 «Про затвердження Положення про порядок реалізації права на академічну мобільність». 
Ключовими аспектами нового положення є надання права на участь у програмах академічної мобільності усім учасникам освітнього процесу; чітке визначення видів та форм академічної мобільності; закріплення принципу перезарахування отриманих кредитів на основі Європейської кредитнотрансферної системи (СКТС), зокрема шляхом порівняння змісту навчальних програм, а не назв курсів; збереження місця навчання та стипендії для студентів та місця роботи для працівників ВНЗ, котрі беруть участь у програмах академічної мобільності.

Порядок здійснення академічної мобільності усіма учасниками освітнього процесу є важливим кроком у процесі імплементації Закону України “Про вищу освіту" та створення дієвого інструментарію для інтернаціоналізації українських вищих навчальних закладів.

Джерелами фінансування міжнародної академічної мобільності являються міжнародні програми, такі Темпус, Еразмус Мундус, Еразмус+ , ДААД (Німеччина), Жан Моне, Марія Кюрі та ін. [12]. На жаль, наша держава, уряд та міністерство освіти майже не виділяють коштів та не фінансують наукові та освітні проекти, пов'язані з міжнародними академічними обмінами, тому переважна більшість українських студентів здійснюють поїздки до закордонних ВНЗ на навчання, стажування, проходження практики або отримавши грант, або на фінансування вищезгаданих програм, або за власний кошт.

Україна - велика європейська держава з населенням понад 40 млн. осіб, понад 70 \% відсотків людей мають вищу освіту. Але потенціал вищої освіти України не використовується повною мірою суспільством і економікою.

Так, за загальним рейтингом «The Good Country Index» 2020 р. серед 153 країн - Україна - на 76-му місці, а найближчі географічні сусіди та країни, які $\epsilon$ безпосередніми конкурентами на ринку освітніх послуг, значно вище: Польща на 31-му, а Німеччина - на 5-му. Україна посідає 1-ше місце за компонентою «Внесок у розвиток науки та технологій» в рейтингу, Польща - на 13-му місці, Німеччина - на 23-му, а Велика Британія - на 5-му, але таке високе місце України пояснюється значно нижчим рівнем ВВП на одну особу, ніж результатами розвитку науки та технологій [3].

Не перший рік Україна потрапляє до рейтингу QS Higher Education System Strength Rankings16, який визначає країни із найсильнішими в світі системами вищої освіти. У цьому рейтингу з 50 досліджуваних країн у 2018 р. Україна посіла 44-те місце. Слід зазначити, що за цим рейтингом Україна випередила Польщу - 46-те місце, але позиції провідних країн поки недосяжні: Велика Британія посіла 2-ге місце, Німеччина - 4-те.

За індикатором «міцності системи», який оцінює загальну міцність національної системи на основі результатів у міжнародних рейтингах, Україна отримала оцінку 16,1 зі 100, Велика Британія - 98,7, Німеччина - 94,3, Польща $-14,1[4]$.

Індикатор доступності системи вищої освіти відображає шанси отримати місце в університеті світового класу для жителів відповідної країни, для України дорівнює 14,4 (зі 100), Великої Британії - 97,6, Німеччини - 97,1, Польщі - 38,5. 
Позитивним для нашої держави в розвитку міжнародної академічної мобільності $\epsilon$ участь у міжнародних освітніх програмах. Так, наприклад, Програма ЄС Темпус (Трансєвропейська програма мобільності для навчання в університетах) надає можливість країнам-партнерам обирати для себе пріоритетні напрями реформування та заохочує всіх зацікавлених виявляти ініціативу, шукати інноваційні підходи, створювати новітні освітні продукти і послуги з урахування кращого міжнародного досвіду [1].

Усі три напрями Програми Темпус - реформування навчальних планів і програм; удосконалення процесів управління в системі вищої освіти; посилення зв'язків між освітою та суспільством - передбачають можливість обміну досвідом між вітчизняними ВНЗ та університетами країн $Є \mathrm{C}$, побудованого на принципі мобільності науково-педагогічних працівників.

Освітня програма ЄС Еразмус Мундус спрямована саме на активізацію міжнародного співробітництва та підвищення мобільності серед студентів, аспірантів, докторантів, викладачів, дослідників європейських університетів та ВНЗ третіх країн на всіх континентах, які мають можливість отримувати стипендії в межах цієї програми для продовження навчання або проведення наукових досліджень у країнах СС [5].

Програма імені Жана Моне - це освітня програма СС, започаткована у 1990 р. $з$ метою пропагування європейської ідеї та поширення європейських студій в Свропі та на інших континентах, у межах якої реалізується мобільність дослідників та викладачів шляхом підтримки викладання дисциплін 3 європейської інтеграції та проведення досліджень у різних університетах Європи, організації міжнародних науково-практичних конференцій, публічних дискусій тощо [3].

Упродовж академічного року 2020-2021 рр. Білоцерківським національним аграрним університетом було реалізовано 1 мобільність студента факультету Ветеринарного факультету на навчання в Естонському університеті наук про життя у м. Тарту, який отримав отримання додаткові компетентності у сфері ветеринарної медицини, а також провів моніторинг та порівняння системи навчання та роботи практикуючих лікарів ветеринарної медицини. Реалізовано 3 мобільності викладачів 3 Афійон Коджатепе університету (Туреччина) для економічного та факультету ветеринарної медицини.

Рекомендації щодо розвитку академічної мобільності як засобу інтеграції України у світовий науково-освітній простір [7]:

Для України досягнення ефективної міжнародної академічної мобільності в контексті Болонського процесу реальне лише за умови створення продуктивної системи національної академічної мобільності, її нормативноправової бази, організаційно-економічного механізму, визначення джерел фінансування та готовності до партнерства суб'єктів процесу академічних обмінів.

3 урахуванням європейського досвіду академічної мобільності, постає спектр завдань, котрі повинні бути вирішені на державному рівні і стати основою вироблення стратегії розвитку академічної мобільності у вищій освіті як однієї з форм ії інтеграції у світовий освітньо-науковий простір: 
Законодавчо-нормативне забезпечення академічної мобільності включає в себе відповідне оновлення державного законодавства щодо вищої освіти; візової підтримки академічної мобільності; захисту прав і безпеки іноземних студентів; розробку внутрішньо-університетського нормативно-правового забезпечення академічної мобільності 3 урахуванням специфіки освітніх закладів; створення механізмів реалізації різних форм академічної мобільності узгоджених із законодавчими положеннями СС та нормами міжнародного права.

Інфраструктурне і матеріально-технічне забезпечення академічної мобільності передбачає створення відповідних структурних підрозділів в штатному розписі ВН3, які повинні організовувати й шукати джерела фінансування міжнародного навчання, стажування й обмінів, надавати інформаційну та консультативну підтримку щодо програм і грантів з академічної мобільності, допомогу в оформленні необхідних документів, візовий супровід, медичне страхування тощо; розвиток інфраструктури ВН3, перш за все, гуртожитків, сучасно оснащеного аудиторного фонду тощо.

Кадрове забезпечення академічної мобільності. Великою проблемою $\epsilon$ майже повна втрата ефективних структур і методики підготовки викладачів та кураторів для роботи з іноземцями, особливо на підготовчих факультетах. Існує гостра необхідність повернення таких напрямків підготовки фахівців, зокрема, в філологічні вузи.

Інформаційне забезпечення і супровід академічної мобільності передбачає створення й щотижневе оновлення багаторівневої інформаційної мережі, яка повинна акумулювати та розповсюджувати актуальну інформацію щодо академічної мобільності для всіх учасників навчального процесу через інтернет-сторінку на сайті ВН3, проведення інформаційних семінарів за певними грантовими й обмінними програмами; створення дієвих механізмів рекламування переваг навчання в Україні для іноземних студентів тощо.

Фінансове забезпечення академічної мобільності передбачає збільшення державної фінансової підтримки участі талановитої та соціально незахищеної студентської молоді в закордонних освітніх програмах; розвиток програм державного та приватного кредитування i субсидування академічної мобільності; пошук грантів; вирішення фінансових аспектів академічних обмінів в рамках партнерства ВНЗ різних країн.

Адаптаційні програми для учасників академічних обмінів передбачають створення відповідних інфраструктур (в першу чергу дієвого кураторства) для підтримки в адаптації іноземних студентів: правової обізнаності, медичного забезпечення, організації побуту й дозвілля, курсів 3 мовної та загальнокультурної адаптації тощо.

\section{Список літератури:}

1. OECD. Internationalization and Traid in Higher Education: Opportunities and Chellenges. - Paris: OECD Publications, 2004. - P. 20-21.

2. Santiago P., Tremblay K., Basri E., Arnal E. Tertiary Education for the Knowledge Society: Social Features, Equity, Innovation, Labour Market, Internationalisation. Vol. 2. I P.Santiago, K.Tremblay, E.Basri, E.Arnal. - Paris: OECD, 2008. - P. 243. 
3. Іноземні студенти додали Україні понад 4 мільярди гривень // Освітній портал Педпреса 24.05.2013 p. [Електронний ресурс]. - Режим доступу: http://pedpresa.com.ua/blog/inozemni-studenty-prynesly-ukrajini-ponad-4...

4. Гуляєва Н. М. Мобільність викладачів і студентів: проблеми та орієнтири / Н.М.Гуляєва // Матеріали VI щорічної міжнародної конференції «Розбудова менеджментосвіти в Україні» (17-19 лютого 2005 року м. Дніпропетровськ). - К.: Навч.-метод. центр «Консорціум із удосконалення менеджмент-освіти в Україні», 2005. - С. 76-81.

5. The Bologna Process 2020 - The European Higher Education Area in the new decade. Communique of the Conference of European Ministers Responsible for Higher Education. Leuven and Leuven-la-Neuve, 28-29 April [Electronic resource]. - Mode of access: http://europa.eu/rapid/press-release_IP-09-675_en.htm

6. Вища освіта України [Електронний ресурс]. - Режим доступу: http:// www. mon. gov.ua/ua/activity/education/58/

7. В Україні збільшилася кількість іноземних студентів [Електронний ресурс]. Режим доступу: http://education.unian.net/ukr/detail/191556

8. Іноземні студенти додали Україні понад 4 мільярди гривень // Освітній портал Педпреса 24.05.2013 p. [Електронний ресурс]. - Режим доступу: http://pedpresa.com.ua/blog/inozemni-studenty-prynesly-ukrajini-ponad-4...

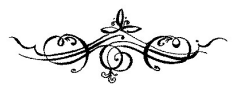

УДК $378.147=161.2$

Лілія Анатоліївна Роман (м. Чернівці, Україна), канд. філологічних наук, Чернівецький відділ Всеукраїнської громадськой організачії Союзу Українок

doi: 10.33245/20-05-2021-65-67

\section{Вивчення української мови на матеріалах культурної спадщини України як потужний чинник у збагаченні світогляду та покращенні адаптації іноземних студентів}

\footnotetext{
Анотація: $y$ статті висвітлено необхідність володіння державною мовою іноземними студентами для їх успішної адаптащії та подальшої соціалізащії в українському суспільстві в прочесі навчання в ЗВО України. Показано переваги при залученні студентівіноземців до феномену украӥнської національної культури через вивчення історії, звичаїв та традииій, ментальності украӥнського народу.

Підсумовано, щчо такий підхід сприятиме самоосвіті, професійному самовдосконаленню та оперативній орієнтації іноземних студентів в культурному, науковому та політичному житті украӥнського суспільства.

Ключові слова: методика викладання іноземних мов, украӥнська мова як іноземна, іноземні студенти, українські звичаї та традиії, культурна спадщина України.

The topic: «Learning of the Ukrainian language on the materials of the cultural heritage of Ukraine as a powerful factor in enriching the worldview and improving the adaptation of foreign students»
} 
Abstract: The article highlights the necessity for students-foreign citizens to learn the state language for their successful adaptation and further socialization in Ukrainian society in the process of studying in the High Establishments of Ukraine. The advantages of involving foreign students in the phenomenon of Ukrainian national culture through the study of history, customs and traditions, the mentality of the Ukrainian people are shown.

It is concluded that such an approach will promote self-education, professional selfimprovement and operational orientation of foreign students in the cultural, scientific and political life of Ukrainian society.

Key words: methods of teaching foreign languages, Ukrainian language as a foreign language, foreign students, Ukrainian customs and traditions, cultural heritage of Ukraine.

Статус української мови як державної зумовлює іï пріоритетне використання в усіх сферах суспільного життя. Володіння державною мовою має особливе значення для соціалізації студентів-іноземних громадян різних національностей, їх успішної адаптації та інтеграції в українське культурне та суспільне середовище у процесі навчання у ЗВО України.

Одним із чинників, який безпосередньо впливає на успішну як особисту, так і професійну соціалізацію, а відтак й адаптацію молодої людини, $\epsilon$ володіння мовою того суспільства, в яке вона планує інтегруватися.

Як зазначає Б. Ананьєв, через вивчення мови можна створити «мовленнєву модель світу» будь-якого етносу, а отже, оволодіння іноземною мовою $\epsilon$ одним 3 найпотужнішим засобом соціалізації та адаптації в будь-якому суспільстві. Володіння мовою суспільства завжди означало стати «своїм серед чужих», розмовляти з представниками соціуму «на одній мові». I якщо такий процес інтеграції завжди є непростим навіть для носіїв рідної мови в рідній країні, то, безперечно, цей процес $є$ набагато важчим для молоді - представників інших націй, інших країн.

Навчання української мови як іноземної через вивчення феномену національної культури, тобто через ознайомлення із здобутками літературної спадщини, 3 історією, 3 культурними та релігійними звичаями і традиціями українського народу дозволяє сформувати в іноземного студента лінгвосоціокультурну компетенцію, забезпечуючи тим самим крос-культурний діалог, міжкультурне спілкування і взаєморозуміння студентів - представників різних національностей.

Усе це збагачує їх знання та розширює їх світогляд про країну, в якій вони навчаються, сприяє подоланню внутрішньої тривоги i формуванню впевненості, що є першоосновою для їх подальшої успішної адаптації та соціалізації.

Як показує практика, на формування лінгвосоціокультурної компетенції студента впливає цілий комплекс чинників: світогляд, світосприйняття, соціальні взаємовідносини, релігія, засоби спілкування, мова тощо. Якщо для носія рідної мови формування вербальних та невербальних структур відбувається в процесі соціалізації, то для студента-іноземця, який вивчає іноземну мову, важливішим є формування навичок і стереотипів мовленнєвої та культурної поведінки як необхідної умови оволодіння культурою іншомовної комунікації. 
Підсумовуючи все вищесказане можемо сказати, що викладання української мови через вивчення культурної, історичної, звичаєвої спадщини українців допоможе студенту-іноземцю краще пізнати культуру та ментальність українського народу, розширити власні культурно-пізнавальні інтереси та збагатити світогляд. Як наслідок, все це сприятиме самоосвіті, професійному самовдосконаленню, продуктивній міжкультурній комунікації та оперативній орієнтації іноземних студентів в культурному, науковому та політичному житті українського суспільства.

\section{Список літератури:}

1. Ананьев Б.Г. О проблемах современного человекознания. - М.: Наука, $-1987 .-380$ с.

2. Бабенко Т. Розкриваючи культуру як глобальне явище (3 досвіду впровадження культурологічного аспекту в навчанні граматики англійської мови як другої) // Іноземні мови в навчальних закладах. -2009 . - № 1.

3. Редьква М. Лінгвокраїнознавчий аспект у курсі української мови як іноземної: реалізація в умовах мовного середовища та іншомовного простору. - Теорія і практика викладання української мови як іноземної. 2013. - Вип. 8. - С. 270-274.

4. Свиридюк Т. Шукаємо і знаходимо своє місце в полікультурній Європі // Іноземні мови в навчальних закладах. -2009 . - № 1.

5. Солонович Н.А. Лингвострановедческий подход как средство повышения мотивации при обучении иностранным языкам в старших классах средней школы: Автореф. дис. кандид. пед. наук. - М., 1995. - 16 с.

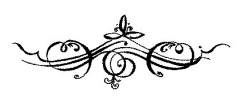

УДК 378.091.3:811.161.2'243

Тетяна Миколаївна Рудакова (м. Біла Церква, Україна - м. Нітра, Словаччина),

канд. філол. наук, дочент, в. о. завкафедри мовної підготовки Міжнародного навчально-наукового інвестииійного иентру Білоцерківського національного аграрного університету;

лекторка украӥнської мови філософського факультету в університеті імені Костянтина Філософа в м. Нітра

doi: $10.33245 / 20-05-2021-67-70$

\section{Особливості використання діалогу-розпитування на заняттях з української мови як іноземної}

Анотація: Визначено основні види і типи діалогів, розглянуто діалог-розпитування, особливості роботи над ним. Акцент зроблено на взаємній роботі всіх учасників діалогурозпитування, чіткому розподілі ролей, створенні комунікативних ситуацій, наближених до природних. 
Виділено основні етапи роботи над діалогом-розпитуванням на заняттях $з$ украӥнської мови як іноземної.

Ключові слова: діалог-розпитування, діалог-домовленість, діалог-обмін враженнями, думками, діалог-обговорення, діалог-дискусія.

The topic: «Features of the use of dialogue-questioning in Ukrainian as a foreign language classes»

Abstract: The main types and kinds of dialogues are defined, dialogue-questioning is considered, features of work on it. The emphasis is on mutual work of all participants of the dialogue-questioning, clear division of roles, creating communicative situations close to natural.

The main stages of work on the interrogation dialogue are highlighted during Ukrainian language classes as a foreign language.

Key words: dialogue-questioning, dialogue-agreement, dialogue-exchange of impressions and thoughts, dialogue-discussion, dialogue-discussion.

Упродовж XXI століття увагу лінгвістів активно привертає діалогбагатоаспектне мовне вище. Науковий інтерес сконцентровано на питанні взаємодії комунікантів: комунікативних намірах, взаємозв'язку, взаємозумовленості, сприйнятті чи несприйнятті інформації, потенціях підтримання діалогу.

Діалогічне мовлення стало об’єктом дослідження таких учених, як: В. Біляніної [1], М. Бранецької [2], Н. Калюжної [3], Т. Лагути [4], В. Лапіної [5], А. Медведчук [6], Л. Солодар [7], В. Шовкового й Т. Шовкової [8] та багатьох інших.

Погоджуючись із Т. Лагутою, зазначимо, що відповідно до інтенціонального критерію можемо розрізняти три види діалогів: комплементарний, компетитивний та координативний [4, с. 204].

Згідно із семантичним критерієм будемо розрізняти інформативні та оцінні діалоги [4, с. 205]. Відповідно до рівня мовленнєвої активності виділятимемо діалог-домовленість, діалог-обмін враженнями і думками та діалогобговорення й дискусію [7, с. 165].

Розглянемо детальніше типи діалогів. Л. Солодар говорить про діалог етикетного характеру, діалог-розпитування, діалог-домовленість, діалог-обмін думками, повідомленнями $[7$, с. 165]. Хоча Т. Лагута зазначає, що класифікувати діалоги потрібно за такими видами: діалог-бесіда (асоціативна бесіда), діалог-розв’язання проблеми, діалог-розпитування, діалог-з'ясування нерозуміння [4, с. 205].

В. Білянина, цитуючи С. Ніколаєву, Д. Уолтона та Е. Краббе, виокремлює такі типи діалогів: діалог-розпитування, діалог-домовленість, діалог-обмін враженнями, думками, діалог-обговорення (дискусія) [1, с. 287 - 288].

В. Лапіна, досліджуючи роботи Л. Панової, І. Андрійко, С. Тезікової, дійшла висновків про те, що за видами діалогічних єдностей потрібно виокремлювати такі типи діалогів: діалог-одностороннє розпитування (запитання - повідомлення - спонукання); діалог-домовленість (повідомлення спонукання - згода); діалог-обмін враженнями (запитання / повідомлення повідомлення); діалог-обговорення (повідомлення - повідомлення) [5, с. 3]. 
Отже, спільними для всіх зазначених вище класифікацій є діалогрозпитування. Його ми і розглянемо детальніше.

Н. Калюжна вважає, що інтерактивне навчання є діалогічним навчанням взаємодії вчителя і учня [3, с. 39 - 40], отже, це розширює межі використання діалогів у навчальній діяльності педагогів. Діалог-розпитування, на думку T. Лагути, структурно $є$ найпростішим, бо складається із запитань та відповідей, послідовно уміщених у структуру діалогу [4, с. 205]. Погоджуємося із думкою дослідниці про те, що студент має вміти формулювати запитання, а також уточнювальні запитання з метою конкретизації певних фактів, важливим $\epsilon$ вміння відповідати на поставлені запитання, продовжити діалог, висловивши сум, радість, впевненість, сумнів тощо.

Зауважимо, що основною умовою успішної побудови діалогу-розпитування на заняттях з української мови як іноземної $є$ своєчасне формулювання зустрічних запитань, а також виключення повторних або детальних відповідей. Ролі мають бути чітко розподілені. Діалог-розпитування має підтримуватися усіма комунікантами. За умови не виконання цих вимог діалог не матиме успішної динаміки.

Важливими $є$ і ситуації, які спонукають учасників до мовлення. У природних ситуаціях ролі розподіляються автоматично, а в штучно створених є необхідність розподілу ролей. 3 метою успішної реалізації комунікативної мети штучні ситуації необхідно максимально наближати до природних. Цікавою є думка В. Лапіної, що діалог-розпитування будується за структурою інтерв'ю [5, с. 5].

Щодо етапів роботи, то рекомендуємо починати 3 рецептивно-репродуктивних вправ i завдань, які $\epsilon$ невеликими за обсягом і легкими для виконання. Пізніше варто працювати над оволодінням діалогічними єдностями, умінням будувати мікродіалоги. Найскладнішим етапом роботи над діалогом вважаємо створення діалогів-розпитувань відповідно до заданої комунікативної ситуації.

Отже, як бачимо, студенти мають активно розвивати навички аудіювання і говоріння під час усної побудови діалогів, а також читання - під час початкового етапу роботи над діалогами на заняттях 3 української мови як іноземної.

\section{Список літератури:}

1. Біляніна В. І. Типи діалогових конструкцій у мові китайської художньої літератури XIX C./ В. I. Біляніна // Нова філологія. - 2014. - № 67. - С. 21-26. URL: http://nbuv.gov.ua/UJRN/Novfil_2014_67_6 (дата звернення: 20.05.2021).

2. Бранецька М. С. Особливості навчання професійно орієнтованого діалогічного мовлення студентів вищих технічних навчальних закладів/ М. С. Бранецька // Наукові записки [Ніжинського державного університету ім. Миколи Гоголя]. - Філологічні науки. 2015. - Кн. 2. - С. 104 - 108. URL: http://nbuv.gov.ua/UJRN/ Nzfn_2015_2_23 (дата звернення: 20.05.2021).

3. Калюжна Н. Використання інтерактивних методів навчання на уроках літературного читання в початковій школі / Н. Калюжна // Humanitarium. 2018. - Том 40. Вип. 2. - С. $38-46$.

4. Лагута Т. Про діалог як форму прояву мовленнєвої діяльності студента / Т. Лагути // Теорія і практика викладання української мови як іноземної. - 2007. - Вип. 2. - С. 204 - 207. 
5. Лапіна В. O. Лінгвістичні основи навчального діалогу. URL: https:// core.ac.uk/download/pdf/168412416.pdf (дата звернення: 20.05.2021).

6. Медведчук А. В. Структура та властивості діалогу-розпитування як засобу іншомовної професійно орієнтованої комунікації майбутніх менеджеррів з адміністративної діяльності URL: https://jrnl.nau.edu.ua > VisnikPP > article > view (дата звернення: 20.05.2021).

7. Солодар Л. В. діалогічне мовлення - основний вид мовленнєвої діяльності при вивченні української мови як іноземної / Л. В. Солодар // Вісник Вінницького політехнічного інституту. - 2011. - № 2. - С. 163 - 167.

8. Шовковий В. М. Комунікативно-стратегічна компетентність в розроблення змісту навчання майбутніх філологів німецької мови (початковий етап) / В. М. Шовковий, Т. А. Шовкова // Наукові записки Тернопільського національного педагогічного університету імені Володимира Гнатюка. - Серія: Педагогіка. 2018. - № 2. - С. 81 - 88. URL: http:// nbuv.gov.ua/UJRN/ NZTNPU_ped_2018_2_13 (дата звернення: 20.05.2021).

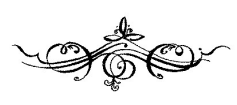

УДК 378.147:811.161.2'243

Слизавета Юріївна Скрипкіна (м. Біла Церква, Україна), асистент кафедри мовної підготовки Міжнародного навчально-наукового інвестищійного цеентру Білочерківський національний аграрний університет

\title{
doi: $10.33245 / 20-05-2021-70-72$
}

\section{Ефективні шляхи свідомого засвосння нової лексики слухачами мовного курсу}

\begin{abstract}
Анотація: У тезах аналізуються ефективні шляхи засвоєння нової лексики слухачами мовного курсу, зокрема способи запам'ятовування лексичних одиниць. Ця якість допомагає інокомунікантам набувати мовленнєві компетениії вже на етапі довузівської підготовки.

Ключові слова: украӥнська мова як іноземна, лексичний запас, лексична одиниця, мнемотехніка, способи запам'ятовування слів, мовленнєві компетенції.

The topic: «Effective ways of conscious assimilation of new vocabulary

by students of a language course»

Abstract: In these theses are analyzed the ways to learn new vocabulary by language course students, in particular, the ways of memorizing lexical units. This quality helps inocomonants to to acquire speech competencies already at the stage of pre-university training.

Keywords: Ukrainian language as foreign language, vocabulary, lexical unit, mnemonics, the ways of memorizing the words, speech competencies.

Для досягнення високого та вільного рівня володіння лексикою мови потрібно докласти багато зусиль. Окрім знання граматики, фонетики, для інокомуніканта дуже важливим $є$ накопичення достатньої кількості слів для спілкування та свідоме опанування цього нового словникового запасу.
\end{abstract}


Механізм вивчення нової лексики, тематичних фраз, мовленнєвих конструкцій $\epsilon$ надзвичайно важливим та цікавим.

Мнемотехніка - це сукупність спеціальних способів, прийомів, котрі полегшують запам'ятовування важливої інформації та збільшують обсяг пам'яті шляхом утворення асоціацій. За допомогою звичайного «зубріння» слів у людини залишається тільки 20 відсотків інформації. Але певні прийоми мнемотехніки учні й студенти зустрічають ще на етапі вивчення фонетики мови. Наприклад, О. Авраменко, М. Блажко пропнують школярам ряд формул мнемотехніки для глибшого засвоєння різних типів звуків у своїх підручниках $\mathrm{i}$ збірниках завдань для складання ЗНО [3].

У мнемотехніці дуже важлива «послідовність запам'ятовування». Йдеться про черговість запам'ятовування складових нового іноземного слова [2]. Існує багато способів запам'ятовування нових слів. Розглянемо найбільш відомі 3 них.

1. Повторення. Доведено, що 50\% нового матеріалу забувається через годину, після отримання. Тому повторення є дуже важливим.

2. Візуалізація. Нову лексику потрібно візуально ЗАКРІПИТИ. Нові слова можна написати чи надрукувати на кольоровому папері або стікерах та приклеїти у ті місця, де велику кількість часу зосереджено ваш погляд. Або безпосередньо на предметах, які вивчаються.

3. Проговорення. Важливим $є$ правильна вимова слів. Тому всі нові слова потрібно проговорити. Потім побудувати власні словосполучення та речення. Таким чином ви пригадуєте попередній матеріал та запам'ятовуєте нові слова.

4. Лексичний квест. Це пошук нових слів у різних джерелах (статтях, іншомовних тлумачних словниках, художній літературі, ФБ сторінках відомих людей. Коли при вивченні нових слів ви бачите речення, де можна їх використовувати, тим швидше ви поповните свій словниковий запас (вокабуляр).

5. Перевірка. Можна влаштувати усні опитування, щоб студент перевіряв студента. (переклад). Так можна прослідковувати успішність та підняти настрій та отримати стимул до подальшої праці.

6. Студент - учитель. Доведено, що найкраще запам'ятовує слова той хто їх навчає та пояснює. Знайдіть студента, який потребує більше уваги, та попросіть сильніших студентів пояснити йому. (потім використайте метод перевірки між студентами)

7. Піктографічний словник. Дає можливість побачити та вивчити нові слова із їхніми візуалізаціями. Такі словники можуть бути розподілені на теми, це $є$ особливо цінним, бо можна поглибити свої знання відповідно до власних потреб.

8. Улюблені nicнi. Якщо вам аудіально сподобалась пісня на іноземній мові - перегляньте ii текст. Таким чином ви зможете запам'ятати правильну вимову та написання слів.

9. Відео, фільми, мультфільми з субтитрами. Під час перегляду кіноплівки із субтитрами ви виокремлюєте нові слова, серед раніше відомих вам. Це дасть змогу збагатити свій словниковий запас новою лексикою. 
10. Створення іноземного середовища свойми руками. По можливості оточіть себе максимально мовою, яку ви вивчаєте. Наприклад, змініть налаштування на комп'ютері чи телефоні, читайте та слухайте новини іноземною мовою.

Перебування в новому інформаційному просторі потребує вміння застосовувати знання на практиці та працювати з новою лексикою. Дослідження підтверджують, що для найефективнішого запам'ятовування нових слів потрібно розширювати мережі нейронних зв'язків у тілі людини.

Простими словами - це поєднання раніше відомого матеріалу з новим, а також систематичне повторення всієї нової та пройденої інформації. Нейронні зв'язки потребують постійної підтримки, треба не допускати розриву цих зв'язків.

У процесі вивчення лексики української мови в Білоцерківському національному аграрному університеті нами був апробований прийом маркування: написання стікерів-етикеток з назвами предметів на кожній з речей в аудиторії. Студенти швидше засвоїли цю лексику, бачили іiі правильне написання. Потім у самих слухачів виробилася звичка писати й кріпити стікери-етикетки на предметах, які їх оточували в університеті та гуртожтку. Коли вчили нові слова нової теми, вони самі писали назви слів і пропонували їх помістити біля цих предметів.

Відомо, що людина краще запам'ятовує інформацію відповідно до свого типу сприймання. Існують такі типи сприймання інформації:

- візуальний (коли людині потрібно щось побачити, щоб це запам'ятати);

- аудіальний (коли людині краще сприймати інформацію на слух);

- кінетичний (коли інформація сприймається за рахунок відчуттів та емоцій);

- дискрети, дігітали (сприйняття інформації з логічної точки зору).

Щоб ефективно використати ці знання, треба досить добре знати своїх здобувачів освіти, їхні психологічні особливості. Викладач має врахувати типи сприйняття інформації своїх студентів, використовувати в своїй практиці різні способи запам'ятовування лексичних одиниць мови 3 метою збагачення лексикону.

\section{Список літератури:}

1. Леонтьев А.Н. Лекции по общей психологии: Учеб. пособие для вузов по спец. «Психология» / Под ред. Д. А. Леонтьева, Е. Е. Соколовой. - Москва: Смысл, 2000. - 509 с.

2. Техніка запамятовування слів. Запам'ятовування слів під час письма та усного мовлення. Код доступу - https://lagopus.ru/uk/tehnika-zapominaniya-slov-zapominanie-slov-vovremya-pisma-i-ustnoi/.

3. Українська мова та література: Довідник. Завдання в тестовій формі: I ч./ Олександр Авраменко, Марія Блажко. - Київ: Грамота, 2020. - 496 с.

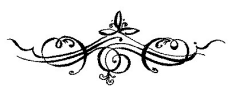


Алла Сергіївна Стадній (м. Вінниця, Україна), канд. філологічних наук, дочент кафедри мовознавства Вінницького національного технічного університету

doi: $10.33245 / 20-05-2021-73-75$

\title{
Організація самостійної роботи студентів у процесі вивчення української мови як іноземної
}

\begin{abstract}
Анотація: Досліджено особливості організачї самостійної роботи студентів у прочесі вивчення украӥнської мови як іноземної. Встановлено, щуо самостійна робота $\epsilon$ важливою формою організації навчальної діяльності у ЗВО. Визначено чинники, які впливають на ефективність організаиії самостійної роботи. Запропоновано різні види самостійної роботи з української мови як іноземної. 3'ясовано роль викладача в організації самостійної роботи студентів. Створення відповідного освітнього середовища сприятиме саморозвитку, активній самостійній роботі студентів.
\end{abstract}

Ключові слова: самостійна робота студента, украӥнська як іноземна, іноземні студенти.

The topic: "Organization of individual work of students in the process of studying Ukrainian as a foreign language»

Abstract: Specifics of the organization of individual work of students in the process of learning Ukrainian as a foreign language are researched. It is established that individual work is an important form of organization of the educational process in the Free Economic Zone. The factors influencing the efficiency of the organization of individual work are determined. Different types of individual work on learning Ukrainian as a foreign language are described. The role of the teacher in the organization of individual work of the students is clarified. Creating an appropriate educational environment will promote self-development, active individual work of students.

Key words: individual student work, Ukrainian as a foreign language, foreign students.

Однією з важливих форм організації навчального процесу в закладах вищої освіти є самостійна робота студентів. Завдання сучасних педагогів - навчити молодь здобувати знання та ефективно використовувати їх в практичній діяльності. Відповідно до програми навчальної дисципліни «Українська мова як іноземна» 252 години відведено на практичні заняття, на самостійне опрацювання матеріалу - 168 годин, тобто 40\% запланованого часу. Тому якість засвоєння дисципліни залежить як від навчання в аудиторії, у тому числі й самостійного, так і від організації самостійної діяльності студентів за межами університету.

Різні аспекти самостійної роботи студентів досліджували В. Безпалько, В. Бондар, Г. Волкова, О. Глотова, М. Гроза, Н. Кузьміна, М. Карпіна, Є. Полат та інші.

Самостійна робота - це важлива складова сучасного навчального процесу. Викладачі розвивають в іноземних студентів уміння самостійно здобувати знання та прагнення до самовдосконалення й саморозвитку. 
Ефективна самостійна робота можлива лише тоді, коли $є$ стійка мотивація. Мотивація до вивчення української мови як іноземної обумовлюється практичною спрямованістю дисципліни, що передбачає вільне та активне спілкування у навчальній, професійній, побутовій та інших комунікативних сферах та сприяє засвоєнню необхідних знань навчально-професійного, наукового, країнознавчого та соціально-політичного характеру.

$\mathrm{У}$ роботі 3 іноземними студентами використовуємо аудиторну (опрацювання теоретичних відомостей, виконання вправ, робота 3 текстами, написання самостійних, контрольних робіт) й позааудиторну самостійну роботу домашні завдання навчального й творчого характеру, серед яких:

1) завдання на закріплення вивченого на уроці матеріалу, тренувальні вправи з граматики, лексики, синтаксису, орфографії;

2) завдання, що передують вивченню нової теми (засвоєння лексики, аналіз граматичних конструкцій, вправи на прогнозування змісту);

3) вправи для систематизації та узагальнення вивченого;

4) завдання для контролю знань та вмінь.

Підвищується зацікавленість студентів і продуктивність самостійної роботи, коли викладач пропонує різнорівневі завдання, серед яких слухач обирає вправи відповідно до своїх знань, інтересів, потреб. Варто пропонувати іноземцям завдання репродуктивного, реконструктивного, евристичного й творчого характеру. Завдання репродуктивного рівня передбачають відтворення здобутих знань, виконання вправ за зразком: написання тренувальних вправ, укладання словника термінів, виконання тестових завдань.

До завдання реконструктивного рівня пропонують ідею його виконання, яку студент реалізовує в конкретний спосіб: складання логічних схем, опорних таблиць, написання анотації до тексту, створення доповіді. Нестандартне завдання евристичного рівня передбачає аналіз проблеми та іiі самостійне розв'язання: складання діалогів на запропоновану тему, розв'язання проблемної ситуації, аналіз відеоматеріалів, використання арттехнологій (малюнок, колаж, синквейн, твір, презентація).

Творчі завдання можна пропонувати студентам 3 високим рівнем самостійності й пізнавальної активності, 3 гнучким мисленням, які здатні встановлювати причинно-наслідкові зв'язки. До таких завдань належать: написання творів, тез, статей, створення кейсів, проєктів.

Важливо добирати завдання 3 різних видів мовленнєвої діяльності: аудіювання, говоріння, читання, письма, які допоможуть оволодіти українською мовою як іноземною для ефективного спілкування в україномовному професійному середовищі з усвідомленим використанням лексичних, граматичних, синтаксичних засобів.

Особливого значення набуває самостійна робота в умовах дистанційного навчання. Використання мережі Інтернет, комп'ютерних технологій заохочує студентів до самостійної роботи доступністю, зручністю. Пропонуємо студентам:

1) онлайн-спілкування;

2) електронне тестування;

3) інтерактивні презентації із завданнями; 
4) дидактичні комп'ютерні ігри;

5) роботу з аудіоматеріалами, з текстами, відео.

Провідна роль в організації самостійної роботи студента належить викладачеві, який зобов'язаний спланувати самостійну діяльність студентів, визначити дидактичну мету, розробити завдання, забезпечити методичними матеріалами, продумати види контролю. Це може бути тестування, усне й письмове опитування, написання творчої роботи, презентація тощо. Аналізуючи якісні показники самостійної роботи, педагог моніторить ефективність навчального процесу і коригує його.

Правильно організована самостійна робота сприяє оптимальному засвоєнню навчального матеріалу, розвитку логічного мислення, мовлення, формуванню потреб саморозвитку. Використання традиційних й інноваційних технологій дозволяє викладачеві реалізувати компетентнісний та особистісноорієнтований підхід.

\section{Список літератури:}

1. Чернуха О. В. Стимулювання іноземних студентів до пошукової діяльності в ході самостійної роботи. URL: http://innovations.kmpu. edu.ua/ENFV/ 2011_1/11ovmsfp.pdf

2. Касьяненко Т.А. Викладання української мови як іноземної: принципи оптимізації та інновації. URL: http://dspace.nbuv.gov.ua

3. Мацько Л. Інноваційні технології викладання української мови як іноземної на підготовчому відділенні університету. Теорія і практика викладання української мови як іноземної. 2011. - Вип. 6. - С. 229-238.

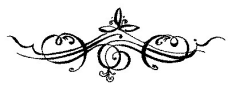

УДК 811.161.

Ірина Семенівна Товт (м. Біла Церква, Україна), канд. історичних наук, викладач украӥнської мови та літератури, доцент КНЗ КОР «Білочерківський гуманітарно-педагогічний фаховий коледж»

\section{doi: 10.33245/20-05-2021-75-78}

\section{Культорологічний підхід до викладання української мови та літератури у ЗВО}

Анотація: У тезах розглядається культурологічний підхід до викладання української мови та літератури у ЗВО.

Акцентується увага на особливостях викладання дисииплін філологічного ииклу у вищому навчальному закладі. Звертається увага на певні недоліки у викладанні української мови та літератури у закладі вищої освіти, досліджується поліфункиіональність украӥнської мови та літератури у зВО.

Ключові слова: культурологічний підхід, українська мова, культурологія, українська література, вищий навчальний заклад. 
The topic: «Culturological approach in teaching Ukrainian language and literature in the institution of higher education»»

Abstract: The theses consider the culturological approach to the teaching of Ukrainian language and literature in institution of higher education.

The focus is on features of teaching disciplines of the philological cycle in an institution of higher education. Attention is payed to certain shortcomings in teaching Ukrainian language and literature in an institution of higher education, multifunctionality of Ukrainian language and literature in the institution of higher education.

Key words: culturological approach, Ukrainian language, culturology, Ukrainian literature, institution of higher education.

Актуальність даного питання зумовлена сучасною системою викладання дисциплін філологічного циклу у вищому навчальному закладі, яка характеризується багатоваріантністю і різноманітністю. Це вимагає узагальнення підходів до визначення змісту i методів викладання мови та літератури. Оновлення змісту освіти створює певні передумови для успішного досягнення виховної мети філологічної освіти: формування духовно-етичних уявлень студентів, їх світогляду, громадянської та етнічної свідомості, розвитку творчих здібностей тощо.

Досвід реформування системи освіти дозволяє констатувати наступні для сучасної вищої школи тенденції: зниження загальноосвітнього та культурного рівня випускників, рівня їх мовної культури, падіння інтересу до навчання взагалі й до вивчення предметів філологічного циклу, зокрема.

Такий стан обумовлюється не лише соціально-політичними причинами, але і певними недоліками у викладанні дисциплін філологічного циклу. Серед них:

- традиційний, автономний шлях вивчення мови та літератури у ВНЗ; нескоординованість цілей навчання, відсутність міждисциплінарних зв'язків, спадкоємності у змісті та структурі означених курсів;

- недооцінювання свідомо-комунікативного підходу до навчання, ролі української мови як засобу спілкування у різних сферах людської діяльності, недостатня увага до розвитку мовної культури студентів, вивчення української літератури як особливого роду словесного мистецтва;

- недосконалість методичного компоненту (використовувані методи викладання української мови і літератури у вищих навчальних закладах, не повною мірою орієнтовані на мовний розвиток студентів, формування їх творчих здібностей, самостійну діяльність щодо набуття та використання знань, співтворчість студентів і викладача тощо);

- недостатність сучасних навчальних, художніх, довідкових, методичних видань з української мови та літератури.

Таким чином, навчальний процес продовжує характеризуватися суперечностями між фронтальними формами організації навчання, одноманітністю дидактичного змісту, переважанням пояснювально-ілюстративного методу викладання, 3 одного боку, та індивідуальними способами набуття знань, індивідуальним темпом навчально-пізнавальної діяльності студента, необхідністю забезпечення діяльнісного характеру учіння - 3 іншого [3, с. 7]. 
Українська мова та література завжди була гордістю, совістю народу. Для української національної психології характерні підвищена увага до душі, сумлінності, яскравого і влучного слова. Мова і література у вищому навчальному закладі виступають поліфункціональними, згідно цілей та завдань, $\mathrm{i}$ поліфонічними за змістом.

У художніх творах порушуються проблеми етики, естетики, політики, а іноді навіть стратегії і тактики бойових битв. Водночас, найголовнішою виступає проблема душі та духу окремої людини і народу в цілому [1, с. 59]. Саме ця проблема повинна бути центральною, домінуючою в курсі вивчення філологічних дисциплін у вищому навчальному закладі.

Говорячи про культурологічний підхід до викладання української мови та літератури у сучасному виші, ми не можемо не звернутися до поняття «культурології».

Культурологія як відносно самостійна наука, як навчальна дисципліна з'явилася порівняно недавно, саме поняття «культурологія» з'явилося на початку XIX століття. Культурологією називають науку про культуру, iї сутність, закономірності, взаємовплив національних культур, цивілізацій $[2$, с. 13]. Культурологія включає в себе теорію культури та історію культур Теорія культури вивчає сутність, закономірності розвитку культури, досліджує процес виникнення і розвитку конкретних, які існували й існують культур, цивілізацій.

За специфіки свого предмета і методів дослідження, культурологію відносять до класу гуманітарних наук. Гуманітарні науки (мовознавство, психологія тощо) в суті є науками про культуру в широкому сенсі слова. Мовознавство, мистецтвознавство, літературознавство, політичні, юридичні науки вивчають різні аспекти, сторони культур, але не вивчають культури в цілому, що $є$ власним предметом культурології як науки.

Тісно культурологія пов'язана 3 історичними науками, особливо в тій iі частині, яку називають історією культури. Культурологія спирається на дані історичних наук, використовує методи при вивченні історії культур. Разом 3 тим культурологія допомагає історії знайти закономірності історичного розвитку, зрозуміти сутність історичних явищ.

Вивчаючи сучасні культури, цивілізації, культурологія як дисципліна почасти збігається 3 такою дисципліною як країнознавство. Як і всі науки, культурологія має певний зв'язок з філософією. Філософія розробляє гносеологічні передумови культурології, як і інших наук. Філософія розробляє необхідні для осмислення культурологічних даних категорії, досліджує специфіку методів пізнання в цій галузі, існує така область філософського знання, як філософія культури.

В культурології широко застосовуються методи історичного пізнання. Мета історичного пізнання - відтворити у виставах історичну реальність, тобто скласти адекватні уявлення про те, що відбувалося насправді в той чи інший період в тій чи іншій країні.

Завдання пізнання «чужих культур» вимагає використання методів «науки про тлумачення», тобто герменевтики. Щоб адекватно зрозуміти представників різних культур, необхідно спробувати поглянути на світ їх очима, 
спробувати уникнути можливою в такому випадку «модернізації», приписуючи їм цінності своєї культури, хоча кожна культура в деякому розумінні індивідуальна, неповторна, тому повне розуміння представників інших культур важко.

Розуміння культур різних націй не самоціль, а засіб для знаходження справжньої, загальнолюдської системи цінностей, для вирішення сучасних актуальних проблем, що стоять перед людством. У цьому сенсі культурологія пов'язана 3 етикою, ідеологією, допомагає виробленню гуманної культурної політики.

\section{Список літератури:}

1. Космакова-Братушенко Т. Як викладати українську мову // Дивослово. - 1997. № 8. - C. 59 .

2. Культурологія: теорія та історія культури. Навч. посіб. Видання 3-тє, перероб. та доп. / За ред. І. І. Тюрменко. - Київ: Центр учбової літератури, 2010. - 370 с.

3. Методика навчання рідної мови в середніх навчальних закладах:Підручник для студентів вищих навчальних закладів освіти / М. І. Пентилюк, А. Г. Гелетова, С. О. Караман та ін.; за ред. М. І. Пентилюк. - К.: Ленвіт, 2000. - 267 с.

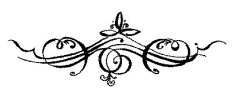

\section{УДК $8.81 ' 23$}

Ірина Володимирівна Черновалюк (м. Одеса, Україна), канд. філол. наук, дочент кафедри мовної та загальногуманітарної підготовки іноземців Інституту міжнародної освіти Одеського національного університету ім. I.I. Мечникова

\section{doi: 10.33245/20-05-2021-78-81}

\section{Інноваційні технології в іншомовному освіту}

Анотація: У статті розглядається роль інновачійних технологій у сфері освіти. Інформаційно-комунікаційні технології визначають розвиток всіх сфер діяльності людини, включаючи сферу освіти. Відзначено роль інформаційних технологій в підвищенні якості мовної підготовки іноземних студентів.

Питання організації ефективного процесу навчання іноземних студентів, високої якості освітніх послуг $i$ ефективної реалізащії сучасних концептиій викладання розглядаються в руслі сучасної концепчії іншомовної освіти.

Ключові слова: інноваційні технології, інформаційно-комунікачійні технології, іншомовна освіта, концепція навчання.

The topic: «Innovative technologies in a foreign world»

Abstract: In this article the role of the innovative technologies in the sphere of education is examined. Information and communication technologies define development of all spheres of 
human activity, including education. The role of innovative technologies in the improving the quality of language training of the foreign students is determined.

The question of organizing an effective process of training of foreign students, of high quality of educational services and effective implementation of modern teaching concepts is considered in the channel of the modern concept of foreign language education.

Key words: innovative technologies, information and communication technologies, foreign language education, concept of education.

\section{Тема: «Инновационные технологии в иноязычном образовании»}

Аннотация: B статье рассматривается роль инновационных технологий в сфере образования. Информационно-коммуникационные технологии определяют развитие всех сфер деятельности человека, включая сферу образования. Отмечена роль информачионных технологий в повышении качества языковой подготовки иностранных студентов.

Bопросы организации эффективного процесса обучения иностранных студентов, высокого качества образовательных услуг и эффективной реализации современных конщепщий преподавания рассматриваются в русле современной концепщии иноязычного образования.

Ключевые слова: инновационные технологии, информационно-коммуникационные технологии, иноязычное образование, концепция обучения.

Теория и методика иноязычного образования развивается в направлении активного внедрения в образовательную систему новых педагогических решений, методических идей и инновационных технологий. Современные тенденции общественного развития и реформирования высшего образования определяют новые требования к личности современного специалиста и его профессиональным характеристикам.

Современные требования к качеству подготовки иностранных специалистов ставят перед системой высшего образования задачу усовершенствования базисных составляющих процесса формирования профессионально-коммуникативной компетенции. «В свете последних общеевропейских тенденций в области требований к качеству подготовки выпускников цель образования сегодня рассматривается не просто как передача и накопление знаний, а как формирование ключевых компетенций, которые подготовили бы человека к реальной профессиональной деятельности в интерактивном обществе» [3, с. 29].

Процесс организации обучения иностранных студентов, обеспечивающий высокое качество образовательных услуг и позволяющий эффективно реализовывать современные концепции преподавания по выбранным ими специальностям, должен быть оптимизирован и эффективен.

Также необходимо учитывать современные тенденции в развитии иноязычного образования и тенденции в сфере профессионального образования с целью развития и модернизации процесса обучения. Современные изменения в системе образования и новые требования к выпускникам вузов предполагают пересмотр концептуальных, содержательных и организационных компонентов учебного процесса и внедрение инновационных подходов. 
Языковая подготовка иностранных учащихся в условиях культурнообразовательной среды высшего учебного заведения реализуется в соответствии с основополагающими принципами лингводидактики, образовательными стандартами и программами, разработанными с учетом современных требований и направлений.

В концепции языковой подготовки иностранных студентов в вузах определены цели и задачи, принципы и содержание, условия реализации языковой подготовки разных категорий иностранцев.

Современные информационные технологии находят широкое применение в образовании, качественно изменяют его как в плане новых форм обучения, так и новых видов достижения цели. В профессиональном образовании инновационные технологии (методы и средства, поддерживающие этапы реализации нововведений) повышают эффективность обучения и воспитания личности, направлены на подготовку высококвалифицированных специалистов, получающих фундаментальные и прикладные знания.

Использование инновационных технологий в учебном процессе способствует повышению качества языковой подготовки и активизации роли самостоятельной работы студентов. К основным инновационным технологиям в образовании относятся информационные технологии, позволяющие увеличить эффективность преподавания (технологии, основанные на использовании компьютеров, обучающие и контролирующие программы); информационные методы преподавания, способствующие повышению качества образования; инновационные формы активизации познавательной деятельности студентов.

На современном этапе развития образования Интернет рассматривается как уникальный поставщик контента и новая коммуникативная среда $[1$, c. 60], а информационные коммуникативные технологии признаются одним из главных приоритетов в преподавании иностранных языков.

Одной из основных задач, стоящих перед высшей школой, является задача подготовки специалиста, владеющего методами и приемами работы с информацией. Применительно к иноязычному обучению данная задача означает важность формирования и развития коммуникативной и информационной компетенции [3, с. 267].

Информационно-коммуникационные технологии определяют развитие всех сфер деятельности человека. От умения человека ориентироваться в информационных потоках как на родном, так и на иностранном языке зависит его успешность и конкурентоспособность как специалиста [3, с. 268], это обусловливает становление иноязычной информационной компетенции как цели иноязычного образования и предопределяет поиск путей её эффективного формирования и развития.

Использование компьютерных технологий в обучении иностранным языкам приводит к изменениям в подходах к организации учебного процесса, проектированию новой образовательной среды, созданию онлайн-курса и учебных материалов. 
Интерактивное обучение с применением мультимедиа, в отличие от традиционного, позволяет реализовать комплекс методических, дидактических, педагогических и психологических принципов, делает процесс познания интересным и творческим. Новый вид познавательной деятельности способствует активизации речевой деятельности и развитию познавательной самостоятельности иностранных студентов, формированию умений самостоятельно осуществлять поиск и ориентироваться в потоке информации.

Таким образом, в современном образовательном процессе особую актуальность приобретает применение информационных технологий. Инновационные подходы к организации и содержанию языковой подготовки иностранных студентов способствуют повышению эффективности, оптимальности и интенсификации учебного процесса в целом. Инновации в организации языковой подготовки, проектирование и создание учебного контента направлены на активизацию речевой деятельности и развитие познавательной самостоятельности учащихся.

\section{Сиисок литературы:}

1. Васянина Е.Ю. Интернет-ресурсы по РКИ: достижения и «детские болезни». Русский язык за рубежом. М. - № 1. - 2004.

2. Дубичинский В. В., Тростинская А. М., $\quad$ Ушакова Н. И. Концепция языковой подготовки иностранцев в вузах Украины. - Русский язык, литература, культура в школе и вузе. Киев: КНУ им. Т. Шевченко. - 2013. - № 2. - С. 43-52.

3. Обдалова О. А. Иноязычное образование в XXI веке в контексте социокультурных и педагогических инноваций. - Томск: Изд-во Томского ун-та, 2014. - 180 с. 